\title{
EFEITO DA PRÉ-CURA NA ESTABILIDADE MICROBIOLÓGICA DE CARNE MECANICAMENTE SEPARADA E ELABORAÇÃO DE UM PRODUTO REESTRUTURADO COM FILÉS DE PEITO DE GALINHAS DE DESCARTE
}

\section{TATIANA PACHECO NUNES}

Dissertação apresentada à Escola Superior de Agricultura “Luiz de Queiroz”, Universidade de São Paulo, para obtenção do título de Mestre em Ciências, Área de Concentração: Ciência e Tecnologia de Alimentos.

P I R A C I C A B A

Estado de São Paulo - Brasil

Julho - 2003 


\section{EFEITO DA PRÉ-CURA NA ESTABILIDADE MICROBIOLÓGICA DE CARNE MECANICAMENTE SEPARADA E ELABORAÇÃO DE UM PRODUTO REESTRUTURADO COM FILÉS DE PEITO DE GALINHAS DE DESCARTE}

\section{TATIANA PACHECO NUNES}

Zootecnista

Orientadora: Profe. Dr ${ }^{\mathrm{a}}$. CARMEN J. CONTRERAS CASTILLO

Dissertação apresentada à Escola Superior de Agricultura “Luiz de Queiroz”, Universidade de São Paulo, para obtenção do título de Mestre em Ciências, Área de Concentração: Ciência e Tecnologia de Alimentos.

P I R A C I C A B A

Estado de São Paulo - Brasil

Julho - 2003 


\section{Dados Internacionais de Catalogação na Publicação (CIP)}

DIVISÃO DE BIBLIOTECA E DOCUMENTAÇÃO - ESALQ/USP

\section{Nunes, Tatiana Pacheco}

Efeito da pré-cura na estabilidade microbiológic a de came mecanic amente separada e elaboração de um produto reestruturado com filés de peito de ga linha de desc arte / Tatia na Pacheco Nunes. - Piracicaba, 2003.

101 p. : il.

Dissertação (mestrado) - - Escola Superior de Agricultura Luiz de Queiroz, 2003.

Bibliografia.

1. Camese derivados 2. Congelamento 3. Conservante de alimento 3. Gali- $\quad$ nhas - Descarte 4. Mic robiologia de alimento 5. Nitrito 6.

Processamento de ali - mentos I. Título

CDD 664.93 
Dedico aos meus pais, Waldo e Almerinda, pela vida, incentivo,carinho e paciência. À minha irmã, Luciana e minha tia Lícia, pelo amor e apoio de toda hora. 


\section{AGRADECIMENTOS}

À minha orientadora, Prof $\stackrel{a}{\text {. Dr }}$. . Carmen J. Contreras Castillo, pela amizade, orientação e incentivo fundamentais para a realização deste trabalho.

À Escola Superior de Agricultura "Luiz de Queiroz" (ESALQ/USP), em especial ao Departamento de Agroindústria, Alimentos e Nutrição pela oportunidade para a realização deste trabalho.

À Fundação de Apoio à Pesquisa do Estado de São Paulo (FAPESP) que financiou a execução deste trabalho.

Ao Conselho Nacional de Desenvolvimento Científico e Tecnológico (CNPq) pela concessão da bolsa para a realização desse trabalho.

Ao CTC - ITAL, que permitiu a realização deste trabalho em suas instalações.

Ao amigo Marco Antônio Trindade pela colaboração na realização desse trabalho.

Aos estagiários e a todos os funcionários, pesquisadores e pós-graduandos do CTC - ITAL que colaboraram comigo para a realização deste trabalho.

Aos amigos Rodrigo, Rafaela, Roberta, Aelson, Débora e Lucimeire pelas risadas e conversas animadas.

À Daniela, Luciana, Marina, Gabriela e Andrew, que mesmo sem nunca terem entendido realmente o que se passava, incentivaram constantemente.

À KERRY INGREDIENTS, pela doação dos ingredientes para a elaboração dos nuggets.

À FRANGO SERTANEJO ALIMENTOS LTDA., pela doação dos frangos e das galinhas para a realização desse trabalho.

E a todas as pessoas que direta ou indiretamente colaboraram para a realização deste trabalho. 


\section{SUMÁRIO}

Página

LISTA DE FIGURAS …............................................................................... viii

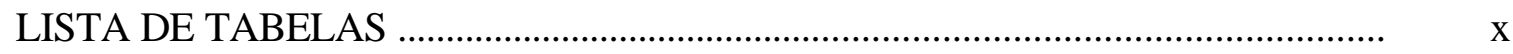

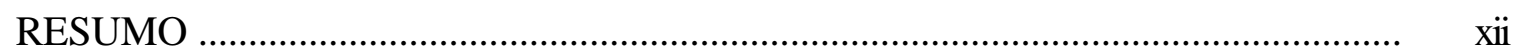

SUMMARY

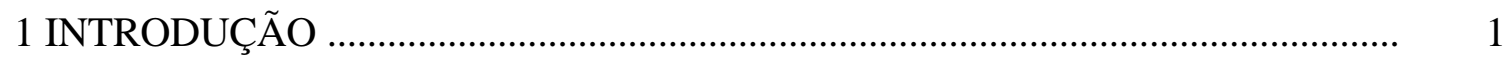

2 REVISÃO DE LITERATURA …...................................................................... 4

2.1 Carnes mecanicamente separadas .......................................................................... 4

2.2 Flora microbiana de galinhas de descarte .............................................................. 9

2.3 Aspectos microbiológicos da CMS ......................................................................... 13

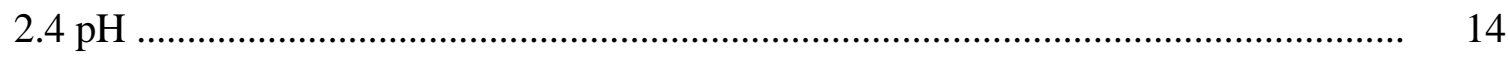

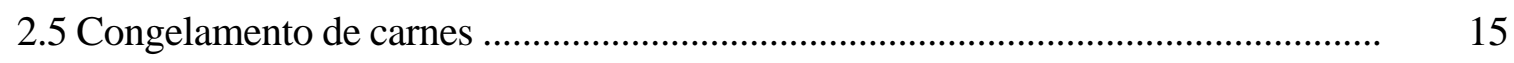

2.5.1 Efeito do congelamento ................................................................................... 15

2.5.2 Crescimento de microrganismos em carnes descongeladas ..................................... 17

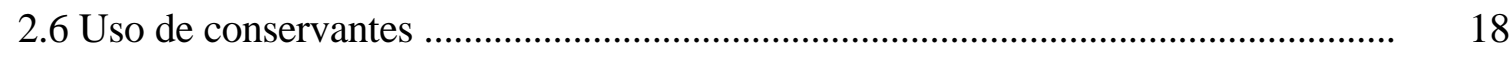

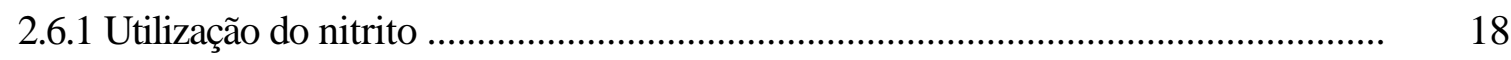

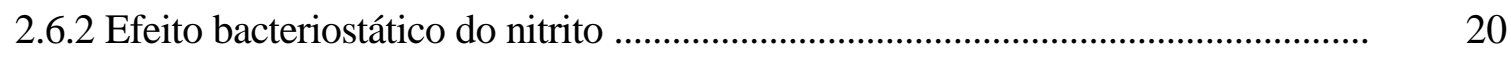

2.6.2.1 Efeito bacteriostático em microrganismos aeróbios ........................................... 22

2.6.2.2 Efeito bacteriostático em microrganismos anaeróbios ........................................ 24

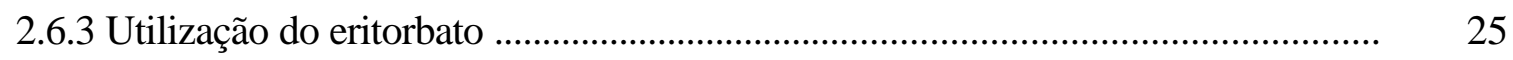

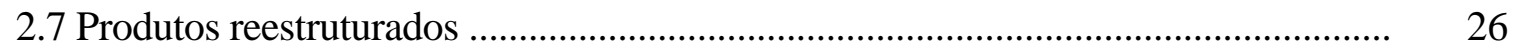

2.8 Capacidade de Emulsificação (CE) ........................................................................ 31

2.9 Capacidade de Retenção de Água (CRA)............................................................... 32 
2.10 Critério de avaliação dos consumidores .............................................................. 33

2.11 Análise sensorial: teste de consumidor ……................................................... 35

3 MATERIAL E MÉTODOS _.......................................................................... 36

3.1 Matéria-prima: CMS ........................................................................................ 36

3.1.2 Extração da CMS ................................................................................... 37

3.1.3 Descongelamento das amostras ....................................................................... 38

3.1.4 Determinação de $\mathrm{pH}$....................................................................................... $\quad 38$

3.1.5 Caracterização microbiológica ...................................................................... 38

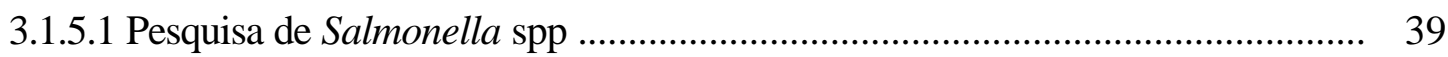

3.1.5.2 Contagem total de bactérias aeróbias mesófilas e psicrotróficas....................... 40

3.1.5.3 Contagem de Staphyloccus aureus .............................................................. $\quad 40$

3.1.5.4 Contagem de Escherichia coli ................................................................ 41

3.1.5.5 Contagem de Clostridium perfringens ...................................................... 41

3.1.5.6 Contagem de Pseudomonas spp. ............................................................... 41

3.1.6 Pré-cura com nitrito e eritorbato de sódio ....................................................... 42

3.1.7 Delineamento experimental ......................................................................... 42

3.1.8 Avaliação da estabilidade microbiológica .......................................................... 43

3.1.9 Análise estatística ...................................................................................... 43

3.2 Matéria-prima: nugget ............................................................................... 43

3.2.1 Caracterização dos filés de peito ....................................................................... 44

3.2.1.1 Composição centesimal .............................................................................. 44

3.2.1.2 Determinação de $\mathrm{pH}$.................................................................................... 44

3.2.1.3 Capacidade de Retenção de Água (CRA) ........................................................ 45

3.2.1.4 Capacidade de Emulsificação (CE) ................................................................. 45

3.2.2 Processamento dos empanados tipo nuggets ..................................................... 45

3.2.3 Critério de avaliação dos consumidores .............................................................. 49

3.2.4 Análise sensorial dos nuggets ..................................................................... 49

3.2.5 Análise estatística ...................................................................................... 51

4 RESULTADOS E DISCUSSÃO ….............................................................. 52

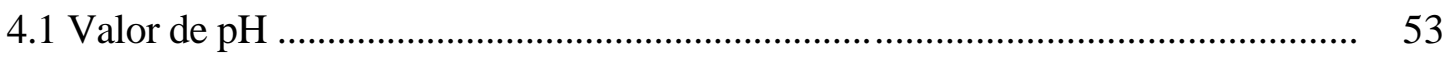


4.2 Caracterização microbiológica das CMSs ......................................................... 55

4.3 Contagem dos microrganismos nas CMSs tratadas e congeladas no $1^{\circ}$ e no $99^{\circ}$ dia $\quad 58$

4.4 Contagem dos microrganismos psicrotróficos ao longo de 99 dias sob estocagem

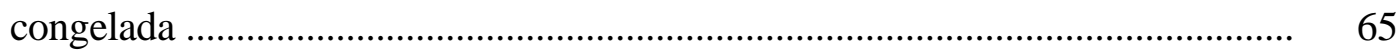

4.5 Caracterização dos filés de peito ………….......................................................... $\quad 70$

4.5.1 Composição centesimal ..................................................................................... $\quad 70$

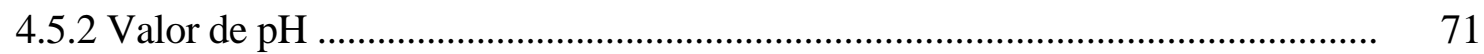

4.5.3 Capacidade de Retenção de Água (CRA) ……………….................................. 72

4.5.4 Capacidade de Emulsificação (CE) .................................................................... 73

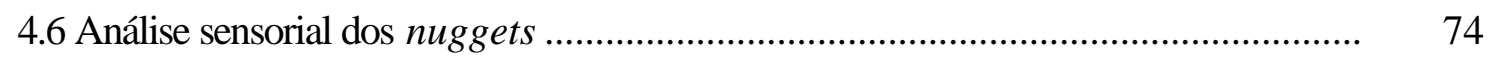

4.6.1 Classe econômica dos consumidores .............................................................. 74

4.6.2 Sexo e faixa etária dos consumidores ............................................................ $\quad 75$

4.6.3 Freqüência de consumo e classe econômica dos consumidores ............................ 76

4.6.4 Aceitação sensorial ..................................................................................... $\quad 78$

4.6.5 Intenção de compra ................................................................................ $\quad 80$

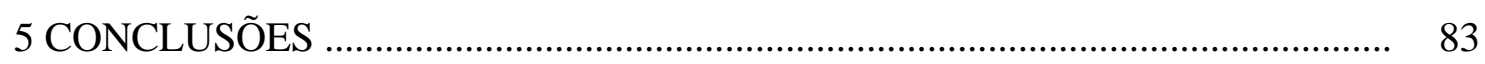

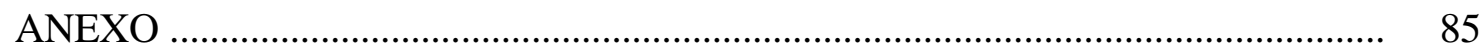

REFERÊNCIAS BIBLIOGRÁFICAS …........................................................ 87 


\section{LISTA DE FIGURAS}

Página

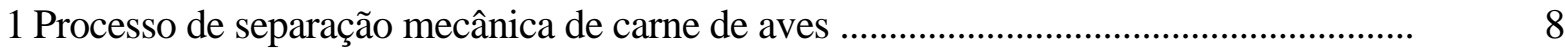

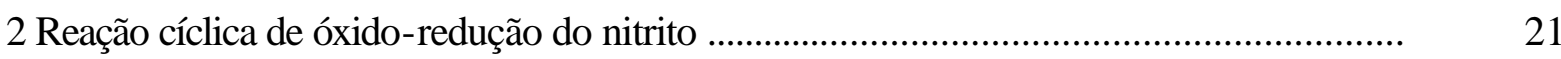

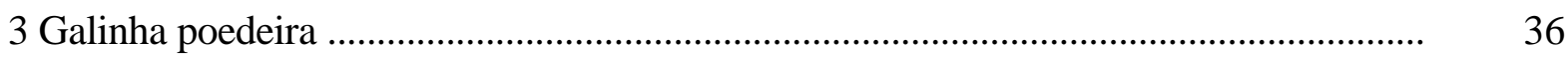

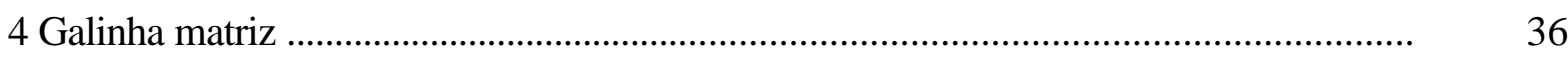

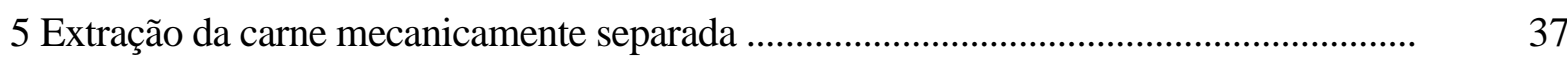

6 Carnes mecanicamente separadas embaladas em sacos de polietileno ............................... 38

7 Matéria-prima utilizada para elaboração dos nuggets (filés de peito e pele) .....................

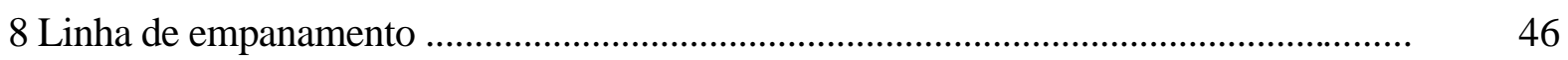

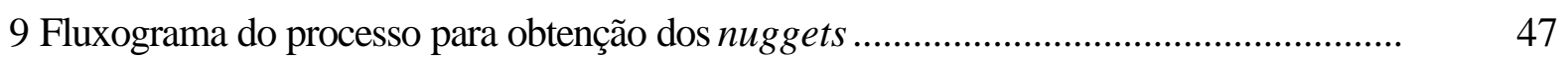

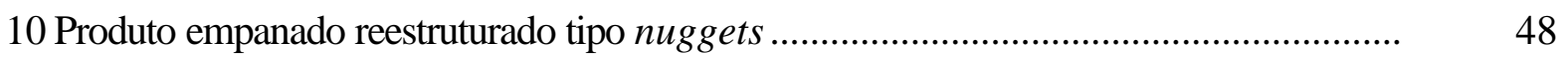

11 Avaliação sensorial dos nuggets ............................................................................. 50

12 Variação na contagem média de mesófilos aeróbios, Pseudomonas e E. coli, durante a estocagem congelada a $-18^{\circ} \mathrm{C}$ em $\mathrm{CMS}$ de galinhas poedeiras tratadas com nitrito (150ppm) e nitrito mais eritorbato $(150 \mathrm{ppm}+500 \mathrm{ppm})$

13 Variação na contagem média de mesófilos aeróbios, Pseudomonas e E. coli, durante a estocagem congelada a $-18^{\circ} \mathrm{C}$ em CMS de galinhas matrizes tratadas com nitrito (150ppm) e nitrito mais eritorbato (150ppm $+500 \mathrm{ppm})$

14 Média da contagem total de microrganismos psicrotróficos durante a estocagem congelada em CMS de galinhas poedeiras tratadas com nitrito (150ppm) e nitrito mais eritorbato $(150 \mathrm{ppm}+500 \mathrm{ppm})$

15. Média da contagem total de microrganismos psicrotróficos durante a estocagem congelada em CMS de galinhas matrizes tratadas com nitrito (150ppm) e nitrito 


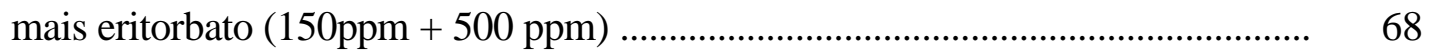

16 Distribuição da classe econômica dos consumidores ................................................. 75

17 Sexo e faixa etária dos consumidores ................................................................... $\quad 75$

18 Freqüência de consumo em relação à classe econômica dos consumidores .............. 77

19 Distribuição dos consumidores em relação ao índice de aceitação dos nuggets (1desgostei muitíssimo e 7- gostei muitíssimo) ............................................................. $\quad 79$

20 Distribuição dos consumidores em relação à intenção de compra dos nuggets ........ 81 


\section{LISTA DE TABELAS}

Página

1 Distribuição das classes econômicas por região .......................................................

2 Formulação utilizada na fabricação dos nuggets ..................................................... 48

3 Cortes do critério de classificação econômica ........................................................ 49

4 Registro das temperaturas $\left({ }^{\circ} \mathrm{C}\right)$ durante o processo de obtenção das CMSs nas três replicações do experimento ..................................................................................... 53

5 Valores médios de $\mathrm{pH}$ das CMSs de galinhas poedeiras controle e tratadas com nitrito e eritorbato ao longo da estocagem congelada $\mathrm{a}-18^{\circ} \mathrm{C}$.............................. 54

6 Valores médios de $\mathrm{pH}$ das CMSs de galinhas matrizes controle e tratadas com nitrito e eritorbato ao longo da estocagem congelada $\mathrm{a}-18^{\circ} \mathrm{C}$............................. 54

7 Valores médios da caracterização microbiológica das CMSs de galinhas matrizes e de galinhas poedeiras ........................................................................................ 56

8 Resumo da análise de variância das análises microbiológicas em CMS de galinhas poedeiras, considerando o valor $\mathrm{F}$ e os níveis de significância

9 Resumo da análise de variância das análises microbiológicas em CMS de galinhas matrizes, considerando o valor F e os níveis de significância

10 Contagem de Staphylococcus aureus em CMSs de galinhas poedeiras e matrizes, no $1^{\circ}$ e no $99^{\circ}$ dia de estocagem congelada a $-18^{\circ} \mathrm{C}(\log 10 \mathrm{UFC} / \mathrm{g})$........

11 Contagem de Clostridium perfringens em CMSs de galinhas poedeiras e matrizes, no $1^{\circ}$ e no $99^{\circ}$ dia de estocagem congelada a $-18^{\circ} \mathrm{C}(\log 10 \mathrm{UFC} / \mathrm{g}) \ldots \ldots .$.

12 Resumo da análise de variância para a contagem de microrganismos psicrotróficos ( $\log 10 \mathrm{UFC} / \mathrm{g})$ em CMS de galinhas poedeiras

13 Resumo da análise de variância para a contagem de microrganismos 
psicrotróficos (log10 UFC/g) em CMS de galinhas matrizes

14 Composição centesimal dos diferentes filés de peito utilizados na elaboração dos nuggets

15 Valor de $\mathrm{pH}$ dos diferentes filés de peito

16 Capacidade de retenção de água dos diferentes filés de peito

17 Capacidade de emulsificação dos diferentes filés de peito $(\mathrm{mL}$ óleo/0,5g de carne)

18 Médias das notas de aceitação dos nuggets . 78

19 Médias das notas de intenção de compra dos nuggets 


\title{
EFEITO DA PRÉ-CURA NA ESTABILIDADE MICROBIOLÓGICA DE CARNE MECANICAMENTE SEPARADA E ELABORAÇÃO DE UM PRODUTO REESTRUTURADO COM FILÉS DE PEITO DE GALINHAS DE DESCARTE
}

\author{
Autora: TATIANA PACHECO NUNES \\ Orientadora: Prof ${ }^{\text {. }}$ Dr ${ }^{\text {- }}$. CARMEN J. CONTRERAS CASTILLO
}

\section{RESUMO}

Os peitos de galinhas matrizes pesadas de corte, poedeiras comerciais brancas e frangos foram desossados manualmente, com o objetivo de avaliar e comparar as propriedades tecnológicas - capacidade de retenção de água e de emulsificação - bem como pH e composição centesimal, além de elaborar e avaliar sensorialmente um produto reestruturado empanado, tipo nugget. Os resultados das análises indicaram que não houve diferença significativa entre as carnes analisadas, nem entre produtos processados, implicando utilização regular desse tipo de matéria-prima na indústria de alimentos. O restante das carcaças das galinhas foi utilizado para extração de carne mecanicamente separada (CMS) para avaliação da estabilidade microbiológica. As CMSs foram submetidas a dois tratamentos: I) com 150ppm de nitrito, embaladas em saco de polietileno; e II) com 150ppm de nitrito e 500ppm de eritorbato, embaladas em saco de polietileno. Como controle, as amostras de CMS foram apenas acondicionadas em sacos de polietileno. Todas as embalagens foram estocadas e congeladas a $-18^{\circ} \mathrm{C}$ por 99 dias. Os resultados da análise de caracterização microbiológica indicaram que tanto as amostras de CMS de galinha matriz quanto de galinha poedeira atenderam os padrões de contagem requeridos pela legislação Brasileira. A avaliação da estabilidade 
microbiológica das CMSs no primeiro e no último dia para mesófilos, Escherichia coli, Staphylococcus aureus, Clostridium perfringens e Pseudomonas, bem como as análises quinzenais de microrganismos psicrotróficos, indicaram que não houve uma redução significativa nas contagens, independentemente do tratamento aplicado. Não foi detectada Salmonella em nenhuma das amostras analisadas. Tais resultados apontaram o tempo de estocagem como o principal fator na redução da carga bacteriana. 


\title{
EFFECTS OF SODIUM NITRITE AND ERYTHORBATE ON MICROBIOLOGICAL STABILITY OF MECHANICALLY DEBONED MEAT AND PROCESSING OF COATED REESTRUCTURED PRODUCT
}

\author{
Author: TATIANA PACHECO NUNES \\ Adviser: Prof. Diª . CARMEN CONTRERAS CASTILLO
}

\section{SUMMARY}

The breasts of heavy fowls, white commercial egg-layers and chickens were manually deboned in order to evaluate and compare technological properties-water hold and emulsifying capacity - and $\mathrm{pH}$ and centesimal composition, as well as to prepare and assess a restructured coated product. The results of the analyses indicated that there was not a significant difference between the meats analyzed, nor among the processed products, implying the regular use of such meat in the food industry. The remaining parts of the hens' carcasses were mechanically deboned for the evaluation of microbiological stability. The mechanically deboned meat (MDM) was submitted to two treatments: I) 150ppm of nitrite, packed in polyethylene bags; II) 150ppm of nitrite and $500 \mathrm{ppm}$ of erythorbate, packed in polyethylene bags. The control meats were just packed in polyethylene bags. All samples were frozen-stored at $-18^{\circ} \mathrm{C}$ for 99 days. The results of microbiological characterization indicated that both samples from heavy fowls and egg-layers were in accordance with the Brazilian legislation. MDM microbiological stability evaluation on the first and last days for fecal coliforms, mesophiles, Staphylococcus aureus, Clostridium perfringens and Pseudomonas, as well as the analyses carried out every fifteen days for psychrotrophics bacteria indicated that there 
was not a significant reduction in the presence of the above, irrespective of the treatment applied. Salmonella was not detected in any of the samples. Such results indicated that freezing storage period was the main factor responsible for the reduction of the bacterial count in MDM. 


\section{INTRODUÇÃO}

As galinhas matrizes pesadas de corte (GM) concentram suas características na produção de pintos comerciais de grande vigor híbrido. São aves grandes, pesando de 3 a $4 \mathrm{~kg}$, com a conformação que se espera de um frango, ou seja, muita carne no peito e nas coxas. Porém também apresentam grande deposição de gordura, tanto subcutânea quanto abdominal. As principais linhagens de corte são Avian Farms, Cobb, Ross, Hubbard, MPK, Vedete e Embrapa (Figueiredo, 2002).

As galinhas poedeiras comerciais (GP) são aves menores, pesando até $1,5 \mathrm{~kg}$, com pouca carne. São criadas sem a presença de machos, visando a produção de ovos. As principais linhagens de postura são Hy-Line, Isa Babcock, Lohmann, Hisex, Nick Chick e Embrapa, com variedades brancas que produzem ovos brancos e variedades de coloração castanho que produzem ovos marrons (Figueiredo, 2002).

Segundo Kondaiah \& Panda (1992), a indústria avícola mundial descarta anualmente 2,6 bilhões de galinhas poedeiras. De acordo com estes autores, a qualidade da carne de frango como matéria-prima para elaboração de produtos tem sido melhorada através da genética, alimentação e manejo, o que não acontece com as galinhas poedeiras, que diferem por serem subprodutos da produção de ovos. Em função disto, existe a necessidade de mais pesquisas para o processamento e utilização destas aves, visando-se obter melhor retorno de mercado.

Com relação às galinhas matrizes, Kondaiah (1993) observou que com o crescente aumento na produção de frangos, a venda de matrizes de descarte a preços razoáveis tem se tornado mais difícil, afetando os lucros dos produtores. Segundo este autor, a distribuição destas aves para consumo doméstico encontra problemas em função 
do grande tamanho (de 3 a 4Kg), excessiva deposição de gordura e aspecto desagradável da pele, além da carne ser mais dura e menos suculenta.

O Brasil conta com aproximadamente 60 milhões de galinhas poedeiras comerciais alojadas. Estimando-se que 2/3 destas aves encerrem seu ciclo de postura a cada ano, 40 milhões de poedeiras são excluídas do plantel, sendo que este grande número de galinhas descartadas contrasta com a falta de mercado consumidor e o baixo valor comercial alcançado por estas aves, que são vendidas a valores próximos a $R \$ 0,30$ a unidade (Garcia et al, 2001). O mesmo raciocínio poderia ser utilizado para as galinhas matrizes de corte, que apresentam um plantel alojado da ordem de 30 milhões de cabeças.

Inicialmente, as carnes de galinhas de descarte eram utilizadas para produção de ração animal ou no preparo de caldos concentrados, sendo utilizada para consumo doméstico apenas sob a forma de canjas e ensopados (Ajuyah et al, 1992; VollerReasonover et al, 1997). Alguns autores (Lee et al., 1997; Rouselle et al., 1984), mostraram o aproveitamento destas aves para a produção de embutidos tipo salsicha e mortadela, utilizando carne mecanicamente separada de galinhas (CMSG).

A carne mecanicamente separada (CMS) é uma matéria-prima com elevada carga microbiana como consequiência da contaminação introduzida durante o processo, em função dessa razão, para melhorar a qualidade da CMS e aumentar a estabilidade durante a vida útil existem diversas alternativas, como a estocagem em atmosfera com $100 \%$ de $\mathrm{CO}_{2}$ e a adição de antioxidantes (Kumar et al., 1986).

O nitrito adicionado aos produtos cárneos não resulta apenas na redução da oxidação e mudanças nos pigmentos, traz também alterações na população microbiana conferindo certa estabilidade bacteriológica ao produto (Roberts \& Dainty, 1991; Shank et al.; 1962).

A utilização do eritorbato associado ao nitrito não só acelera e estabiliza a cor característica das carnes curadas, como possui um efeito seqüestrante no cátion do ferro aumentando a eficiência antibotulínica do nitrito (Tompkin et al., 1979).

Como forma de agregar maior valor à carne de galinhas de descarte, algu ns pesquisadores tem estudado a produção de empanados e reestruturados, que apresentam 
grande aceitação em redes de "fast-food", restaurantes institucionais e como produtos de conveniência (Rouselle et al, 1984; Roland et al., 1981; Seideman et al., 1982; Baker et al., 1984; Hollender et al, 1987). No entanto, poucos trabalhos foram realizados no sentido de compará-los a produtos feitos com carne de frango, que é a matéria-prima normalmente utilizada pela indústria. A elaboração de produtos utilizando carne de peito de galinhas poderia apresentar problemas com relação à textura, visto que animais mais velhos apresentam a carne notadamente mais dura (Roland et al., 1981). Outro problema poderia ser causado devido ao aumento da intensidade do aroma apresentado por animais mais velhos (Rouselle et al, 1984).

A presente investigação teve como principais objetivos caracterizar microbiologicamente a carne mecanicamente separada de galinhas matrizes e galinhas poedeiras, avaliar a influência da pré cura com nitrito e nitrito associado ao eritorbato na estabilidade microbiológica da CMS estocada sob congelamento durante noventa e nove dias, além de elaborar e avaliar sensorialmente um produto reestruturado tipo nugget utilizando os filés dos peitos das galinhas visando um melhor aproveitamento da matéria-prima. 


\section{REVISÃO DE LITERATURA}

\subsection{Carnes mecanicamente separadas}

Em todo processo de desossa, após a retirada dos cortes cárneos normais, sempre resta uma certa quantidade de carne firmemente ligada aos ossos. A carne mecanicamente separada (CMS) é o produto resultante da separação mecânica das carnes presentes nestes ossos. Normalmente a separação mecânica é feita em ossos de formato irregulares, mais difíceis de serem totalmente desossados de forma manual, como aqueles da coluna vertebral e do pescoço. Porém outros ossos com carne aderida ou mesmo carcaças inteiras também podem ser submetidos à separação mecânica. As primeiras máquinas de desossa ou separação mecânica foram desenvolvidas para peixes, no Japão, no final da década de 1940. Este processo surgiu da necessidade da indústria pesqueira em aproveitar a carne de inúmeras espécies de peixes que eram subutilizadas e da crescente demanda por produtos que podiam ser produzidos com a carne mecanicamente separada de peixes. A separação mecânica de carne de aves iniciou-se no final da década de 1950 nos Estados Unidos por razões diferentes. A preferência dos consumidores por cortes de frango ao invés de frangos inteiros e posteriormente a demanda por filés e produtos de conveniência, levou à necessidade de se encontrar meios de aproveitar dorsos, pescoços e ossos resultantes dos processos de desossa. Com isso, as carnes mecanicamente separadas de aves tornaram-se disponíveis e começaram a ser utilizadas na fabricação de inúmeros produtos, como salsichas, mortadelas, salames e sopas em pó (Field, 1988; Froning, 1981).

A Instrução Normativa $n^{\circ}$ 4, de 31 de março de 2000, da Secretaria de Defesa Agropecuária do Ministério da Agricultura e do Abastecimento define Carne Mecanicamente Separada (CMS) como a carne obtida por mecânico de moagem e 
separação de ossos de animais de açougue, destinada a elaboração de produtos cárneos específicos.

$\mathrm{Na}$ legislação canadense, CMS significa um produto cárneo que não contenha mais que $0,027 \%$ de cálcio para cada $1 \%$ de proteína do produto, ou quaisquer partículas ósseas maiores que $2 \mathrm{~mm}$ de tamanho e que tenha sido obtida pela remoção da maior parte do osso e cartilagens de um produto cárneo cominuído dos quais os ossos e as cartilagens não tenham sido previamente removidos (Beraquet, 2000).

$\mathrm{Na}$ comunidade européia, a CMS é dividida em dois grupos. Um grupo é definido em Carne Mecanicamente Recuperada por separação severa, que significa a carne obtida de ossos com exceção os da cabeça, das extremidades dos membros abaixo das juntas carpal e tarsal, produzida para estabelecimentos aprovados pelos regulamentos da União Européia. O outro grupo é definido em Carne Mecanicamente Recuperada por separação suave, que significa a carne obtida de ossos com remoção dos tendões e tecidos conectivos. Esse tipo de carne é utilizado em embutidos crus, tipo lingüiça (Nurmi \& Ring, 1999).

Comparando essas definições, observa-se que a definição Brasileira engloba procedimentos de controle da qualidade relativos ao manejo da carne, enquanto a Canadense incorpora restrições quanto à composição da carne e a proposição européia diferencia as carnes obtidas por diferentes tecnologias (Beraquet, 2000).

Atualmente o processo mais comumente usado para a separação mecânica de aves consiste em cortar a matéria-prima inicial, separar os ossos e tendões da carne utilizando uma rosca sem fim no interior do equipamento para forçar a passagem em cilindros perfurados ou em placas justapostas com um espaço entre si que funcionam como uma peneira. Desossadores mecânicos podem processar de 230-9100 kg/hora dependendo do tipo e da capacidade do equipamento (Froning \& McKee, 2001).

Os novos equipamentos geralmente têm como princípio o uso de dois estágios de compressão: num primeiro estágio o material é submetido a uma pressão suave para remover a carne da superfície dos ossos evitando a incorporação da medula óssea; a carne obtida mantém sua integridade e poderia ser considerada carne moída. Num segundo estágio, a carne é comprimida contra uma rosca sem fim contra uma peneira 
similar às máquinas de um estágio só e a carne obtida é considerada CMS. Esse equipamento tem como rendimento $40 \%$ para operação à baixa pressão e $30 \%$ para a operação subseqüiente à alta pressão, utilizando -se dorsos de frangos (Beraquet, 2000).

Muitos fatores relacionados com o equipamento podem afetar a qualidade do produto final. Por exemplo, a pressão aplicada sobre a matéria-prima, quando aumentada, permite uma maior quantidade de ossos, tendões e outros resíduos não cárneos no produto final, tornando o processo sensivelmente menos eficiente. $\mathrm{O}$ rendimento da CMS de aves varia de 55 a $70 \%$. Quanto maior o rendimento maior a porcentagem de cinzas e lipídeos, além de elevar a temperatura do produto final promovendo a desnaturação das proteínas, o que pode afetar na sua funcionalidade, diminuir a qualidade bacteriológica e conseqüentemente adquirir uma menor vida útil. A manutenção do equipamento é outro fator que afeta a qualidade, as superfícies cortantes devem estar sempre afiadas, pois influenciam na textura e consistência do produto final (Froning \& McKee, 2001).

Schnell et al. (1974) observaram que, quanto menor a tela utilizada no separador mecânico menor era o tamanho das miofibrilas (foram observadas quebras nas bandas $\mathrm{Z}$ ou M). Além disso, o tutano é liberado dos ossos durante o processo de separação contribuindo, deste modo, para aumentar o teor de lipídeos e componentes heme na CMS e diluindo o total de proteína na carne mecanicamente separada.

A CMS é composta de tecidos musculares, adiposos e conectivos e sua composição é dependente da matéria-prima utilizada, por exemplo, a composição de uma CMS extraída de galinhas de descarte tem de 13,9-14,2 \% de proteína; 60,1-65,1\% de umidade e 18,3-26,2\% de gordura (Essary, 1979; Grunden et al., 1972). Quando a matéria-prima utilizada foi dorso e pescoço de frango, o teor de proteína variou de 9,314,5\%; o teor de umidade de 63,4-66,6\% e o teor de gordura de 14,4-27,2\% (Froning, 1981; Grunden et al., 1972). Outros fatores que podem influenciar a composição da CMS são a relação de músculo e osso, a idade da ave, a quantidade de pele, os cortes das aves, o tipo de desossadora mecânica e a espécie. Aves mais novas geralmente têm maior teor de lipídeos e componentes heme no tutano, influenciando a composição química. A quantidade de pele pode aumentar de modo significativo a porcentagem de 
gordura, enquanto o colágeno da pele é encontrado em sua grande maioria no resíduo ósseo (Froning \& McKee, 2001).

A Instrução Normativa $n^{\circ} 4$ de 31 de março de 2000 da Secretaria de Defesa Agropecuária do Ministério da Agricultura e do Abastecimento, recomenda para a conservação e ou transporte dos ossos das carcaças ou partes de carcaça, que sejam adotadas relações de tempo/temperatura que assegurem as características de qualidade para posterior utilização na separação mecânica. A legislação não sugere apenas uma única combinação de tempo e temperatura, algumas dessas combinações são: a) manter os ossos, carcaças e partes de carcaças em temperatura de até $10^{\circ} \mathrm{C}$ e separar mecanicamente em um prazo não superior a 5 horas; b) manter a matéria-prima em temperatura de até $4^{\circ} \mathrm{C}$ e separar mecanicamente em um prazo não superior a 24 horas; c) manter a matéria-prima em temperatura de $0^{\circ} \mathrm{C}$ e separar mecanicamente em um prazo não superior a 48 horas. Lembrando que é necessário monitorar a temperatura ao longo do prazo do armazenamento antes da separação.

Outro pré-requisito durante o processo de separação mecânica é que os ossos, carcaças ou partes de carcaças não deverão ser acumulados na sala de separação. A temperatura dessa sala não deve exceder $10^{\circ} \mathrm{C}$ e a CMS deverá seguir imediatamente para refrigeração ou congelamento. Sendo este último processo o mais utilizado nos abatedouros brasileiros.

Ainda de acordo com a mesma Instrução Normativa, a CMS que não for utilizada diretamente como ingrediente de um produto cárneo logo após o processo de separação mecânica poderá: a) ser refrigerada a uma temperatura não superior a $4^{\circ} \mathrm{C}$ por no máximo 24 horas; b) ser utilizada em até 72 horas após sua obtenção caso seja armazenada no máximo a $0^{\circ} \mathrm{C}$; c) se congelada, a CMS deverá estar em forma de blocos com espessura máxima de $15 \mathrm{~cm}$, conservada a uma temperatura não superior a $-18^{\circ} \mathrm{C}$ no prazo máximo de 90 dias. Em todos os casos, deverão ser rigorosamente observados os padrões microbiológicos e proíbe-se o congelamento de CMS resfriada, se vencido o seu prazo de conservação, conforme descrito no primeiro e segundo caso.

Em relação ao transporte, a Instrução Normativa n4 declara que a CMS poderá ser transportada resfriada em temperatura não superior a $4^{\circ} \mathrm{C}$ por tempo não superior a 
24 horas, ou poderá ser alternativamente transportada resfriada em temperatura não superior a $0^{\circ} \mathrm{C}$ e por um tempo não superior a 72 horas, devendo-se avaliar criteriosamente os padrões microbianos e a oxidação da CMS. O sistema de transporte deverá seguir os princípios de Boas Práticas de Fabricação, sendo o material em contato com a CMS de plástico ou aço inox, previamente limpos e desinfetados.

A limpeza e desinfecção dos equipamentos instalações deve ocorrer em intervalos de tempo suficiente para garantir a higiene em cada turno de operação segundo as Boas Práticas de Fabricação.

Após a separação mecânica o resíduo ósseo é utilizado pela indústria de ração animal, e segundo Froning \& McKee (2001), esse resíduo tem um excelente potencial para produzir proteína isolada. Com o aumento das preocupações das questões ambientais a utilização do resíduo ósseo se tornará prioridade.

Através da Figura 1 pode-se observar as etapas do processo de separação mecânica, os produtos finais dessa separação e a principal utilização dada à CMS e ao resíduo ósseo.

galinhas de descarte ou aves (frango, peru)

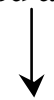

cortes ou desossa manual ou mecânica

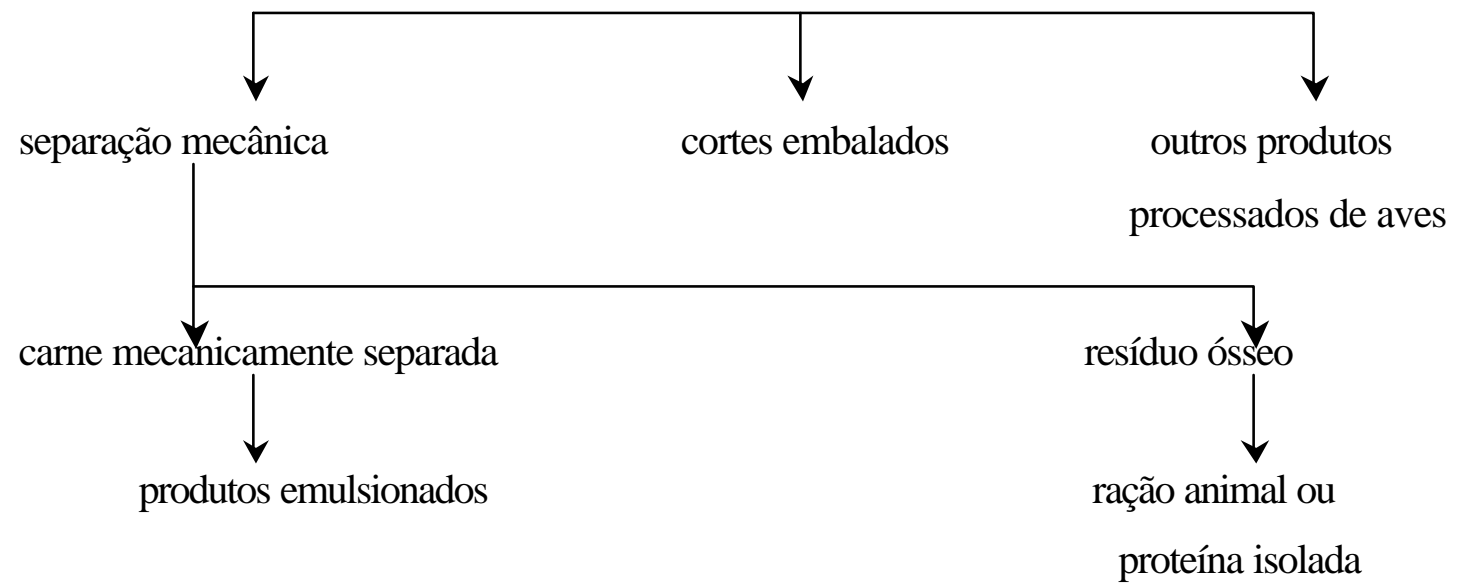

Figura 1 - Processo de separação mecânica de carne de aves. 


\subsection{Flora microbiana de galinhas de descarte}

A carga microbiológica das aves é determinada por vários fatores, tais como espécie e saúde do animal vivo, condições antes e durante o abate, resfriamento da carcaça, condições sanitárias de manuseio, tipo de embalagem e condições de distribuição e estocagem (Lowry \& Gill, 1985).

A carne de aves é formada por tecidos musculares, uma pele aderida a esses tecidos e tecidos conectivos. Embora existam similaridades entre a carne vermelha e a carne de aves, existem importantes diferenças. Em uma carcaça inteira de ave, a pele que rodeia os tecidos musculares serve como uma barreira física para os microrganismos, que podem por outro lado contaminar de modo implícito esse tecido muscular. A pele, portanto, será o primeiro lugar de atividade microbiana na carcaça aliada a ação da depenadora mecânica, que deixa a pele com pequenos orifícios expondo os folículos e permitindo a entrada de contaminantes durante o processo. $\mathrm{O}$ teor de gordura intramuscular das aves é menor que o teor de gordura encontrado logo abaixo da pele e da cavidade abdominal (Mead, 1995).

Os principais gêneros de bactérias presentes nas carcaças e disseminadas durante o processamento são: Acinetobacter, Achromobacter, Aerobacter, Actinomyces, Alcaligenes, Arthrobacter, Bacillus, Clostridium, Cryptococcus, Eberthella, Escherichia, Flavobacterium, Klebsiella, Lactobacillus, Microbacterium, Micrococcus, Oospora, Penicillium, Preoteus, Pseudomonas, Rhodortorula, Salmonella, Sarcina, Staphylococcus, Streptococcus, Streptomyces, e Yersinia. Esses vários gêneros podem ser divididos em dois grupos: patogênicos e não patogênicos. A maioria dos microrganismos pertence ao grupo dos não patogênicos, pois são a principal causa da deterioração dos alimentos (Ayres et al. 1950; Cox \& Bailey, 1987; Kraft, 1971).

Antes do processamento, a população majoritária da microbiota é constituída basicamente de Micrococcus spp. Durante o processamento, essa microbiota predominantemente gram-positiva é em grande parte removida e substituída por uma população heterogênea composta principalmente de bactérias gram-negativas. Embora as penas e os pés das aves estejam contaminados com uma microbiota variada oriunda do piso das gaiolas, grande parte dessa flora é morta durante o escaldamento, e a pele da 
carcaça recém depenada se torna livre de psicrotróficos. Por outro lado, a recontaminação pode ocorrer durante a remoção dos pés e cabeça, evisceração e processos de resfriamento, sendo a água e o gelo, em particular, as principais fontes de Pseudomonas presentes na flora final. Deste modo, todas as carcaças e miúdos sempre estarão contaminados por microrganismos deterioradores no momento do acondicionamento, mesmo quando forem utilizadas boas práticas de produção. Esses microrganismos irão crescer mesmo a baixas temperaturas de refrigeração e deteriorar o produto (Lowry \& Gill, 1985).

Ayres et al (1950) reportaram que imediatamente após o processamento das aves, as bactérias psicrotróficas representaram aproximadamente 50-60\% da microbiota e as Pseudomonas e formas extremamente relacionadas significaram cerca de 20-25\%. $\mathrm{O}$ restante dos microrganismos se constituiu das outras bactérias.

Kraft (1971) observou que a deterioração se tornou evidente, quando houve a formação de limo e do odor não característico. A atividade bioquímica das Pseudomonas também foi demonstrada através de mudanças na proteína e gordura, o que levou à formação de odores desagradáveis. Bactérias do gênero Alcaligenes também foram detectadas no limo das carnes alteradas.

Nagel et al. (1960) observaram a microbiota em cortes de frango embalados em bandejas e indicaram que, de cento e três isolados, oitenta e oito pertenciam ao gênero Pseudomonas, dois pertenciam ao gênero Seromonas e treze ao grupo AchromobacterAlcaligenes.

As temperaturas de refrigeração são muito baixas para permitir o crescimento de microrganismos mesófilos, deste modo, os psicrotróficos são os microrganismos predominantes. Mesmos sob temperaturas mais elevadas, os mesófilos crescem de forma muito lenta, sendo incapazes de competir com as espécies psicrotróficas. Somente quando a temperatura começa a se aproximar do máximo para o crescimento dos psicrotróficos, cerca de $30^{\circ} \mathrm{C}$, os mesófilos começam a dominar a flora deteriorante (Gill \& Newton, 1980).

Segundo Gill \& Newton (1978), além do grupo das Pseudomonas, existe um segundo grupo de aeróbios gram-negativos, o grupo do Acinetobacter/Moraxella, que 
pode contribuir de forma substancial em carnes onde o último $\mathrm{pH}$ é elevado, porém não tem a tendência de produzir compostos de odor desagradável, em função do baixo potencial de deterioração.

Os microrganismos mais freqüentes associados a problemas de saúde pública envolvendo carne de aves são: Salmonella spp., Staphylococcus aureus, Clostridium perfringens e Campylobacter spp. (Simonsen, 1995).

As bactérias da espécie Clostridium perfringens se apresentam em forma de bastonetes, gram-positivos, anaeróbicos facultativos, esporulados com esporo subterminal e sem motilidade. Produzem lecitinase, hemolisinas e $\mathrm{H}_{2} \mathrm{~S}$, reduzem o nitrato, fermentam a lactose, liquefazem a gelatina e durante a fase de esporulação produzem toxina de natureza protéica. As células vegetativas do Clostridium perfringens são sensíveis ao congelamento e a estocagem congelada, mas os esporos são extremamente resistentes. Entretanto, tanto os esporos quanto as células vegetativas podem sobreviver durante longos períodos de estocagem congelada e permanecerem viáveis ao crescimento durante o descongelamento (Fung, 1987).

Essa bactéria é comumente encontrada no meio ambiente e no trato intestinal de humanos e aves e, portanto as aves podem ser contaminadas através do solo, fezes ou da manipulação durante $\mathrm{o}$ abate e processamento. As aves entram na planta de processamento com uma alta concentração de $C$. perfringens principalmente nas penas do peito e nos pés. Após a escaldagem e a depenagem, poucas bactérias permanecem nas carcaças e apenas podem ser encontradas em um número significativo no ceco (Lillard, 1971).

A fase lag do ciclo de vida do $C$. perfringens é curta e, portanto esses microrganismos podem dobrar em número a cada 812 minutos sob ótimas condições de temperatura. Por essa razão é necessária a implantação de uma manipulação adequada dos alimentos de modo a evitar os surtos de toxinfecções alimentares implicados a essa bactéria (Cox \& Bailey, 1987).

As bactérias do gênero Salmonella pertencem ao grupo patogênico mais importante associada à carne de aves. Possuem forma de bastonetes, pequenos, gramnegativo, não esporulados que fermentam glicose usualmente com produção de gás, mas 
não fermentam a lactose nem a sacarose. São microrganismos anaeróbios facultativos, sendo assim pouco afetados pelas variações do potencial de oxi-redução do substrato. Embora a Salmonella, em comum com outras bactérias gram-negativas, sejam altamente sensíveis ao congelamento e descongelamento, uma proporção de células sobreviverá e muitas dessas sobreviventes irão persistir durante a estocagem congelada e serão capazes de crescer durante o processo de descongelamento (White \& Hall, 1984b).

O gênero Staphylococcus, pertencente à família Micrococcaceae, é composto por cocos gram-positivos, não esporulados, desprovidos de motilidade e agrupados irregularmente na forma de cacho. Geralmente são catalase positiva, possuidores de metabolismo respiratório e fermentativo, são anaeróbios facultativos e toleram altas concentrações de $\mathrm{NaCl}$. O Staphylococcus aureus, bem como várias outras espécies de coccos gram-positivas, é particularmente resistente ao congelamento e moderadamente resistente a estocagem congelada. Entretanto, o congelamento não pode ser confiável a ponto de garantir uma redução significativa no nível de contaminação de $S$. aureus, e o prolongamento do período de estocagem congelada não irá reduzir o potencial de crescimento durante o processo de descongelamento subseqüente (White \& Hall, 1984b).

O gênero é produtor de um grande número de toxinas, causando uma grande variedade de quadros patológicos em homens e animais. Atualmente são conhecidos cinco diferentes tipos de enterotoxinas, A; B; C com três subtipos: C1, C2, C3; D e E (Bergdoll, 1979).

Elliot \& Straka (1964) reportaram que a vida de útil de aves congeladas após o descongelamento foi comparável com aves não congeladas quando armazenadas a $2^{\circ} \mathrm{C}$, com base na contagem total de psicrotróficos e na análise sensorial de odor. Concluíram também que o tempo de congelamento não afetou a vida útil após o descongelamento. Resultados similares também foram registrados por Spencer at al. (1961), os quais compararam a vida útil a $1,1^{\circ} \mathrm{C}$ de frangos congelados por 2-12 semanas e descongelados com frangos não congelados. 


\subsection{Aspectos microbiológicos da CMS}

A CMS é uma matéria-prima com elevada carga microbiana como consequiência da contaminação introduzida durante o processo. As pequenas partículas e a grande área de superfície, a liberação de fluídos celulares ricos em nutrientes devido à maceração do tecido e o calor gerado durante o processo de desossa mecânica, propiciam o desenvolvimento bacteriológico (Kumar et al., 1986). A CMS por sua composição, estado físico e elevado $\mathrm{pH}$, constitui-se um meio adequado para proliferação bacteriana e como conseqüência, adquire uma menor vida útil sob refrigeração, tornando-se um sério problema para o processamento futuro (Maxcy et al., 1973). Entretanto, segundo Froning (1981), a CMS é microbiologicamente semelhante à carne moída, se esses produtos forem manipulados e processados adequadamente o crescimento bacteriológico pode ser efetivamente controlado.

A garantia da qualidade bacteriológica na produção cárnea deve ser integrada a um sistema de segurança baseado primeiramente na seleção da matéria-prima, de modo a evitar a colonização e proliferação durante o processo, e na manutenção da qualidade inicial do produto através de técnicas de estocagem e distribuição, com o objetivo de evitar a contaminação e o crescimento bacteriano (Bijker et al, 1987).

Em geral pode-se dizer que, se o número de bactérias na superfície da carne exceder a $1 \times 10^{8} \mathrm{UFC} / \mathrm{g}$, a carne será inviável para o consumo humano. Se a contagem microbiológica for de $1 \times 10^{7} \mathrm{UFC} / \mathrm{g}$, a carne não terá boa qualidade, e sendo assim esse tipo de material não poderá ser considerado matéria-prima para a obtenção de CMS (Nurmi \& Ring, 1999).

A microbiota contaminante da CMS de aves é composta principalmente de bactérias patogênicas, como Salmonella, Clostridium perfringens, Bacillus sp., coliformes fecais, Staphylococcus aureus, Streptococcus fecalis e microrganismos psicrotróficos como Pseudomonas, Achromobacter e Flavobacterium (Ostovar et al., 1971).

A bactéria Clostridium perfringens, é considerada uma das três principais causadoras de surtos de toxinfecções de origem alimentar nos Estados Unidos, sendo principalmente isolada na pele de pescoço e na superfície de aves cruas. A incorporação 
da CMS na formulação de outros produtos tais como salsichas pode servir como inóculo de $C$. perfringens, bem como de outras bactérias. Enquanto as células vegetativas das bactérias são prontamente destruídas em temperaturas de cozimento; os esporos, por sua vez, podem ser induzidos à germinação (Lillard, 1977).

Foram reportados por Kumar et al. (1986) os resultados das contagens microbiológicas de CMS à temperatura de $7^{\circ} \mathrm{C}$, com contagem de mesófilos de $10^{5}-10^{7}$ UFC/g, contagem de coliformes $10^{4} \mathrm{UFC} / \mathrm{g}$, Streptococcus fecalis $10^{4} \mathrm{UFC} / \mathrm{g}$ e Clostridium spp. $10^{4} \mathrm{UFC} / \mathrm{g}$.

Ostovar et al. (1971) investigando a qualidade microbiológica de CMS de aves detectaram uma contagem média de psicrotróficos de 4,6×10 UFC/g.

Maxcy et al. (1973) encontraram resultados na qualidade microbiológica semelhante tanto para CMS quanto para carnes desossadas manualmente. Ambos os produtos mostraram uma carga microbiana inicial de aproximadamente $1,0 \times 10^{5} \mathrm{UFC} / \mathrm{g}$ que aumentou até $1,0 \times 10^{8} \mathrm{UFC} / \mathrm{g}$ aos quatro dias seguintes ao armazenamento a $5^{\circ} \mathrm{C}$. A microbiota isolada foi predominantemente de espécies de Bacillus sp. e bacilos gramnegativos.

Para melhorar a qualidade da CMS e aumentar a estabilidade durante a vida útil existem diversas alternativas que podem ser utilizadas, a pasteurização, a estocagem em atmosfera com $100 \%$ de $\mathrm{CO}_{2}$, a utilização de culturas "starters" como Pediococcus cerevisiae e Lactobacillus plantarum, a adição de antioxidantes e ácido cítrico (Kumar et al., 1986).

\section{$2.4 \mathrm{pH}$}

Geralmente as CMSs apresentam valores de $\mathrm{pH}$ mais elevados do que as carnes desossadas manualmente. A elevação do $\mathrm{pH}$ é principalmente resultante da incorporação de medula vermelha, a qual apresenta $\mathrm{pH}$ na faixa de 6,8 - 7,4. O tutano armazena constituintes indesejáveis como metais pesados e colesterol, mas também benéficos como o ácido ascórbico e ferro (Field, 1988). Segundo Beraquet (2000), a carne de peito desossada manualmente apresenta $\mathrm{pH}$ entre 5,8 - 5,9 e a coxa entre 6,2 - 6,3; enquanto CMSs apresentam valores entre 6,5-7,0. Estes altos valores de $\mathrm{pH}$ contribuem para 
aumentar a perecibilidade microbiológica das CMSs, porém, favorecem a capacidade de retenção de água.

\subsection{Congelamento de carnes}

\subsubsection{Efeito do congelamento}

O congelamento é uma importante técnica na conservação dos alimentos. A atividade microbiológica em alimentos congelados é controlada pela limitação da atividade de água e diminuição da temperatura do produto, deste modo a qualidade do produto pode ser mantida por um longo período. Entretanto o congelamento faz pouco para reduzir a flora bacteriana nos alimentos, além de existir a possibilidade de bactérias patogênicas ou deteriorantes sobreviverem durante a estocagem congelada causando as toxinfecções de origem alimentar ou a deterioração do alimento após o descongelamento (Takano et al., 1979).

Enquanto alguns microrganismos são destruídos durante o congelamento, muitos podem sobreviver em diferentes estágios de viabilidade. $\mathrm{O}$ número de células bacterianas injuriadas, mortas e intactas no alimento congelado depende de vários fatores como, por exemplo, alguns constituintes dos alimentos, que podem aumentar ou reduzir a resistência das células bacterianas ao congelamento. A resistência é reduzida na presença de certos íons, sais inorgânicos, ácidos e certas enzimas (Speck \& Ray, 1977).

Segundo Christophersen (1968), na maioria das vezes pode-se dizer que microrganismos que exibem uma grande resistência ao calor, radiação e conservantes também são mais resistentes a injúria pelo frio e vice-versa.

Em princípio existem cinco fatores que podem causar danos às células durante o congelamento: a baixa temperatura; a formação de gelo extracelular; a formação de gelo intracelular; a concentração extracelular de solutos à medida que a água extracelular é progressivamente congelada como gelo puro; e a concentração intracelular de solutos à medida que a água celular migra para o congelamento e se concentra no meio extracelular. A baixa temperatura e a formação de gelo extracelular não são as únicas causas da destruição celular. Grande parte dos microrganismos pode permanecer viável 
após a desidratação, deste modo a concentração intracelular de solutos não é a principal causa de injúria microbiana. Mais propriamente, o dano celular no congelamento se dá devido à formação de gelo intracelular e/ou a concentração de solutos extracelulares (Lowry \& Gill, 1985).

Embora as causas básicas de injúria e destruição celular durante o congelamento sejam de certo modo conhecidas, os efeitos quantitativos não podem geralmente ser previstos devido a diversos fatores que podem influenciar a taxa de sobrevivência. Os fatores relevantes incluem a natureza dos microrganismos, a composição do alimento, a temperatura de congelamento, o tempo de armazenamento congelado e o processamento e a sanificação do alimento (Delazari, 1980).

Segundo Janssen \& Busta (1973) existem dois tipos de injúria celular, a injúria que pode ser medida pelo aumento da necessidade nutricional para a recuperação das células e a injúria medida pelo aumento da sensibilidade aos agentes seletivos presentes no meio de cultura. Em ambos os casos de injúria, as células podem ser reparadas sob condições específicas.

Segundo Trakulchang \& Kraft (1977), enquanto o processo de congelamento consegue reduzir no primeiro dia cerca de $38-75 \%$ o número de células vegetativas, o número de esporos permanece aproximadamente constante durante todo período de congelamento.

É sabido que o congelamento lento resulta em uma maior destruição de microrganismos que o congelamento rápido. A razão para isso é que durante o congelamento lento, um gradiente intra e extra celular é formado em toda célula danificando a estrutura celular. Durante o congelamento ultra-rápido (nitrogênio líquido a aproximadamente $-190^{\circ} \mathrm{C}$ ) tal gradiente não é formado minimizando a injúria na estrutura celular dos microrganismos, além de haver a formação de pequenos cristais de gelo intracelulares promovendo um menor dano à célula. $\mathrm{O}$ congelamento lento também tende a aumentar a sobrevivência de bactérias mesófilas ao invés de psicrotróficas (Barbut, 2002a).

O processo de congelamento destrói em maiores proporções a flora microbiana presente na carne mecanicamente separada por ter natureza cominuída, pois como as 
bactérias estão distribuídas através da massa, estas ficam mais expostas aos efeitos dos solutos que os organismos presentes apenas nas superfícies dos cortes cárneos. O efeito do congelamento sobre as bactérias também depende do estado fisiológico desses organismos, as células na fase exponencial são mais susceptíveis que as células na fase estacionária (Lowry \& Gill, 1985).

Segundo Sulzbacher (1950), a qualidade sanitária dos alimentos congelados é altamente dependente da maneira e da rapidez com a qual eles foram manipulados antes do congelamento e após a remoção da estocagem congelada.

Os microrganismos podem ser divididos em três grupos quanto à resistência ao congelamento. Os sensíveis, no qual estão incluídas as células vegetativas, bem como \$ bactérias gram-negativas pertencentes ao grupo dos coliformes, Pseudomonas, Achromobacter e Salmonella, embora esta última seja aparentemente um pouco mais resistente. O grupo dos microrganismos levemente resistentes, que são as bactérias gram-positivas, tais como Staphylococcus aureus e Enterococcus. Em função da maior resistência ao congelamento quando comparada com a E. coli, a análise de Enterococcus é recomendada como indicadora de contaminação fecal em alimentos congelados; e o terceiro grupo, o dos microrganismos resistentes ao congelamento, o qual é formado por esporos; os esporos de Bacillus e Clostridium são altamente resistentes, enquanto os esporos de fungos estão agrupados nos levemente resistentes (Christophersen, 1968).

Pressupondo que a temperatura durante a estocagem congelada permaneça abaixo do mínimo para o desenvolvimento da microbiota, nenhuma proliferação microbiana deverá ocorrer (Lowry \& Gill, 1985).

\subsubsection{O crescimento de microrganismos em carnes descongeladas}

O crescimento microbiológico após o descongelamento depende primariamente da temperatura do descongelamento e do tamanho da amostra. Elliot \& Straka (1964) reportaram que a vida de prateleira a $2^{\circ} \mathrm{C}$ para carne de frango moída descongelada foi similar à carne que não foi conge lada.

Segundo White \& Hall (1984b), o crescimento de S. aureus durante o descongelamento não foi afetado pelo período de estocagem e foi bem menor quando 
comparado com o crescimento da Salmonella. Observoutse a diminuição da contagem total de microrganismos durante a estocagem congelada, entretanto detectou-se contagens semelhantes de células viáveis após 24 horas de descongelamento a 20 e $27^{\circ} \mathrm{C}$ em todos os períodos de estocagem $\left(0,7,21,28,56,112\right.$ e 168 dias) a $-18^{\circ} \mathrm{C}$ e conseqüentemente uma deterioração em todos os casos.

Durante a estocagem congelada, os microrganismos que fazem parte da microbiota encontram-se na fase estacionária desde que a temperatura esteja abaixo da mínima para o crescimento. Esse crescimento não é iniciado logo depois de alcançada a temperatura de descongelamento, pois normalmente ocorre a fase lag, e sua duração dependerá do estado em que se encontra a bactéria e da temperatura de descongelamento. A duração dessa fase pode ser muito importante, à medida que, dada as condições apropriadas, o descongelamento pode ser consumado antes da flora deterioradora entrar na fase exponencial. Há evidências que a duração dessa fase lag aumenta com o aumento do período de estocagem congelada (Lowry \& Gill, 1985).

Maxcy et al. (1973) observaram que a $5^{\circ} \mathrm{C}$ havia dois dias de fase lag após o descongelamento para carne de frango moída antes do início do rápido crescimento bacteriano.

Segundo Sulzbacher (1952), a fase lag em carne suína e bovina moída descongelada teve duração de pelo menos 48 horas. Houve alguma aceleração no crescimento durante o período de dois a cinco dias, mas sem grande aumento na contagem e após o quinto dia os microrganismos entraram na fase log.

\subsection{Uso de conservantes}

\subsubsection{Utilização do nitrito}

$\mathrm{O}$ nitrito $\left(\mathrm{NO}_{2}\right)$ vem sendo utilizado há séculos no processo de cura e preservação de carnes, peixes e certos tipos de queijos, este possui pelo menos três funções básicas, primeiramente contribuir com o sabor, que pode ser devido a inibição do desenvolvimento do sabor residual de ranço; em segundo lugar, reagir com a mioglobina e formar o nitrosohemocromo, o qual origina a cor rósea característica de produtos curados; e em terceiro lugar, inibir o crescimento de Clostridium botulinum. Esta 
bactéria anaeróbica produz uma neurotoxina das mais naturalmente letais conhecidas. $\mathrm{O}$ nitrito, associado ao cozimento e adicionado de sal $(\mathrm{NaCl})$ é uma proteção contra o botulismo, intoxicação de origem alimentar provocada pela ingestão da toxina préexistente no alimento (Cammack et al., 1999).

Antes de ser reconhecido como inibidor do crescimento de esporos de $C$. botulinum e sua respectiva toxina, e como agente precursor de compostos potencialmente carcinogênicos, o nitrito era empregado como ingrediente ativo e sua concentração era controlada inicialmente para promover um nível adequado de conversão da mioglobina endógena para a forma nitrosil de modo a evitar uma possível metahemoglobinanemia nos consumidores, principalmente em crianças abaixo de 3 meses de idade. Essa anemia é causada pela reação do nitrito com a hemoglobina, oxidando-a e tornando-a menos efetiva no transporte de oxigênio. Porém com o passar dos anos e estudos cada vez mais avançados, legislações específicas para a utilização do nitrato vêm sendo adotadas em todo mundo como o objetivo de restringir cada vez mais o uso desse ingrediente (Walters, 1991; Watson, 1993).

$\mathrm{O}$ nitrito e nitrato aparecem na dieta em diferentes fontes. Os vegetais são as maiores fontes de nitrato, por exemplo, folhas de alface possuem teores variando de 90 $13000 \mathrm{ng} / \mathrm{kg}$, e tubérculos como batata possuem um teor médio entre $57-1000 \mathrm{mg} / \mathrm{kg}$ (Walters, 1991). A portaria $\mathrm{n}^{\circ} 1004$, de 11 de dezembro de 1998 da Agência Nacional de Vigilância Sanitária (ANVISA, 2003), permite a incorporação máxima de 150ppm de nitrito de sódio $\left(\mathrm{NaNO}_{2}\right)$ em produtos cárneos curados no Brasil, de modo a garantir a segurança alimentar dos consumidores.

Embora os conservantes permitidos em alimentos sejam considerados seguros, o nitrito em altas concentrações é indubitavelmente tóxico ao ser humano e em doses de aproximadamente 1 grama passa ser letal. Ele age como um agente nitrosante que sob condições apropriadas produz compostos nitrosos, alguns dos quais são específicos e potencialmente carcinogênicos. O nitrito é convertido em óxido nítrico, um agente nitrosante ativo o qual reage com as aminas secundárias para formar as nitrosaminas carcinogênicas (Cassens, 1997). 
Sob o ponto de uma possível toxidez e carcinogênese, as formulações da cura vem sendo progressivamente modificadas e o nitrito, ao invés de nitrato, vem sendo adicionado em produtos cárneos curados sempre em baixas concentrações garantindo a segurança alimentar (Marriot et al., 1981).

Geralmente é aceitável que $40 \mu \mathrm{g} / \mathrm{g}$ de nitrito sejam suficientes para atingir e manter a coloração estável de cura, porém uma concentração muito maior pode ser exigida dependendo do teor de sal, do $\mathrm{pH}$ inicial, da temperatura de estocagem, da presença de outros aditivos químicos, do processamento térmico e da carga inicial da contaminação bacteriana no produto(Roberts et al., 1981).

\subsubsection{Efeito bacteriostático do nitrito}

A adição do nitrito não resulta apenas nas mudanças dos pigmentos, mas também traz modificações qualitativas na população bacteriana. Microrganismos do gênero Pseudomonas e Achromobacter são os principais responsáveis pela deterioração da carne fresca. Em carnes curadas, por outro lado, essa flora predominantemente gram-negativa de saprófitas aeróbicas é substituída por bactérias gram-positivas facultativas do grupo ácido lático (Shank et al., 1962).

$\mathrm{O}$ nitrito no $\mathrm{pH}$ da carne $(5,5$ a 6,5) existe em equilíbrio com o ácido nitroso $\left(\mathrm{HNO}_{2}\right)$, este nas condições prevalecentes da carne, é reduzido a óxido nítrico (NO), o qual reage com a mioglobina para produzir o pigmento vermelho da carne curada (Shank et al., 1962).

Historicamente existiram várias teorias a respeito do papel do nitrito como agente bacteriostático. A priori pensou-se que como o óxido nítrico reagia com os pigmentos heme da carne, poderia do mesmo modo reagir com as enzimas das bactérias gramnegativas destruindo-as. Essa hipótese era baseada no crescimento acentuado de bactérias gram-positivas, catalase negativas nas carnes curadas.

O crescimento bacteriano em carnes curadas é afetado pela composição química da cura (carboidratos, fosfatos, etc.), pelo processo de defumação ou cozimento, pela temperatura e composição da atmosfera gasosa durante o armazenamento (Roberts \& Dainty, 1991; Sofos et al., 1980). 
O nitrito possui efeito antimicrobiano, o qual confere considerável estabilidade bacteriológica ao produto, porém existem diversos fatores que influenciam na ação do nitrito: o $\mathrm{pH}$, o potencial redox e o teor de ferro (Roberts \& Dainty, 1991).

A dinâmica do nitrito pode ser visualizada na Figura abaixo, onde há uma reação cíclica de óxido-redução resultando na formação de ácido nitroso, dióxido de nitrogênio, óxido nítrico e nitrato.

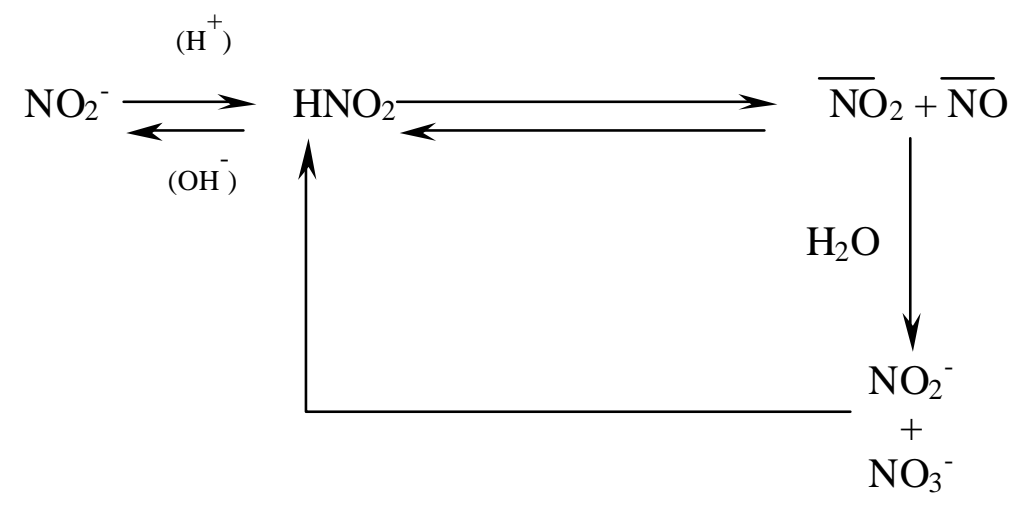

Figura 2 - Reação cíclica de óxido-redução do nitrito.

Segundo Shank et al. (1962), o maior efeito bactericida do nitrito $\left(\mathrm{NO}_{2}{ }^{-}\right)$ocorre quando o pH se encontra entre valores intermediários (4,5-5,5). Nestas condições, o ciclo gira de forma mais lenta e a presença de ácido nitroso $\left(\mathrm{HNO}_{2}\right)$ é prolongada. Por outro lado, em valores mais elevados $(6,0$ e 7,0) há um equilíbrio, esse ciclo é interrompido e nenhum efeito bactericida pode ser notado. Quando o $\mathrm{pH}$ se torna menor que 4,5 o ácido nitroso é rapidamente convertido a nitrato e óxido nítrico, exaurindo a capacidade bactericida do nitrito.

$\mathrm{Na}$ presença de oxigênio, entretanto, o óxido nítrico é oxidado a dióxido de nitrogênio, o qual em um sistema aquoso forma ácido nítrico e ácido nitroso, porém na ausência de oxigênio o óxido nítrico e o nitrato são acumulados e nenhum deles possuem características antibacterianas. $\mathrm{O}$ ácido nitroso formado através da oxidação do óxido nítrico, como mostrado na Figura 2, pode ter duas áreas fundamentais de reação, uma na célula bacteriana e outra com os vários constituintes do meio tornando-o inviável para entrar no metabolismo. A razão da seleção das bactérias gram-positivas sobre as 
gram-negativas em carnes curadas pode eventualmente ser explicada nesses termos (Castellani \& Nivean, 1955).

Sob condições aeróbias, os efeitos tóxicos do óxido nítrico nas células bacterianas são influenciados pela presença de oxigênio e por elementos oxidantes derivados, tal como peróxido. Desse modo, sob estas condições, o efeito bacteriostático do óxido nítrico pode ser diminuído enquanto elementos mais reativos, como o peroxinitrito, estiverem envolvidos. Este pode ser formado a partir da reação do óxido nítrico com o superóxido ou íon de nitroxil com o oxigênio (Cammack et al., 1999).

O potencial redox também afeta a atividade do nitrito contra algumas bactérias e esse efeito inibitório é aumentado em condições anaeróbicas, onde o potencial redox é diminuído (Roberts \& Dainty, 1991).

Em relação à segurança microbiológica e o teor de nitrito residual, Roberts \& Dainty (1991) reportaram que o teor de nitrito residual não foi a chave da fração antimicrobiana, mas sim o nitrito o qual reagia com a massa cárnea.

Christiansen et al. (1978) sugeriram que os esporos de C. botulinum germinaram irregularmente através do período de estocagem enquanto o teor de nitrito residual diminuía com o tempo. Foi alegado que os esporos, os quais germinaram enquanto teores de nitrito foram detectados, morreram. Entretanto, quando não foi detectado nitrito residual os esporos cresceram e produziram toxinas. Por outro lado essa teoria se torna inadequada quando aplicada em produtos curados contendo isoascorbato, nos quais não foi detectada a produção de toxina após seis meses de estocagem, mesmo sem nitrito residual.

Ainda de acordo com Christiansen et al. (1978), a perda do teor de nitrito é dependente de inúmeros fatores, incluindo o processo de pasteurização, o pH do produto, a adição de isoascorbato e a temperatura de estocagem.

\subsubsection{Efeito bacteriostático em microrganismos aeróbios}

O nitrito é uma molécula reativa a qual pode modificar diversos componentes celulares, entretanto as modificações que realmente contribuem para a ação conservante do nitrito não são tão simples de serem compreendidas (Buchman \& Hansen, 1987). 
Segundo Yarbrough et al. (1980), o nitrito inibe o consumo de oxigênio, a fosforilação oxidativa e o transporte ativo. A inibição da respiração e do transporte ativo ocorre coordenadamente, provavelmente porque a inibição do transporte ocorre via a inibição da cadeia de citocromos e deste modo previne-se a formação de um gradiente de prótons, entretanto também é altamente possível que o nitrito tenha um efeito inibitório separado do sistema respiratório e dos carregadores de transporte ativo. O nitrito também age como um desacoplador ocasionando um colapso no gradiente de prótons através da membrana celular; além de conseguir inativar certas enzimas e modificar centros de ferro-enxofre.

Um efeito direto nos componentes da membrana da célula bacteriana foi demonstrado por Buchman \& Hansen (1987), os quais relacionaram a inibição do nitrito com o crescimento e germinação de esporos de Bacillus cereus associado a uma reação específica aos grupos sulfidrilas. O nitrito não apenas protegeu contra a incorporação do iodoacetato (reagente específico sulfidrila) para o interior das membranas, como também protegeu contra a perda irreversível da viabilidade causada pela associação da carboximetilação dos grupos sulfidrilas. Lavando as células inibidas pelo nitrito com água, reverteu-se a inibição e também a eliminação do efeito protetor contra o iodoacetato.

Buchanan \& Solberg (1972) analisaram a interação do nitrito de sódio, oxigênio e $\mathrm{pH}$ no crescimento de Staphylococcus aureus e reportaram que o $\mathrm{pH}$ foi o fator primordial na inibição da bactéria quando esta foi cultivada sob condições aeróbicas, tornando insignificante o efeito do teor de nitrito utilizado.

Bayne \& Michener (1975) observaram o crescimento de Salmonella e Staphylococcus aureus inoculadas em salsichas pós-processamento contendo ou não nitrito de sódio. Verificaram que o efeito inibitório do nitrito foi fortemente dependente do $\mathrm{pH}$, e que na concentração permitida na carne (156ppm) com pH acima de 6,0 o nitrito foi ineficaz. Observaram também, que a concentração de nitrito presente nas salsichas convencionais foi insuficiente para prevenir o crescimento dos microrganismos estudados, concluindo que a omissão do nitrito não apresentou nenhum novo risco ou perigo desses organismos para a saúde humana. 
Entretanto Hasiak et al. (1984) estudando presuntos elaborados com carne de peru com teores de zero ou $52 \mathrm{ppm}$ de nitrito de sódio, verificaram que estes apresentaram contagens de microrganismos mesófilos e psicrotróficos significativamente superiores aos presuntos que continham níveis maiores de nitrito (78, 104 e 156ppm).

A maioria dos alimentos processados é formulada com um certo nível de nitrito, porém devido à formação de nitrosaminas, novos estudos estão sendo direcionados para encontrar uma alternativa para a eliminação ou redução nos níveis de nitrito adicionado (Bushway et al., 1982; Lin et al., 1980; Vareltziz et al., 1984).

\subsubsection{Efeito bacteriostático em microrganismos anaeróbios}

O sistema fosforoclástico (quebra oxidativa do piruvato a acetato) é o principal caminho que leva a síntese de ATP em muitas bactérias do gênero Clostridium e depende da atividade de duas enzimas ferro-enxofre (ferredoxina e a piruvato ferredoxina oxidoredutase). A piruvato ferredoxina oxidoredutase (PFO) catalisa a descarboxilação oxidativa do piruvato na reação fosforoclástica e a ferredoxina transfere os elétrons da piruvato desidrogenase para a hidrogenase na formação de hidrogênios na reação fosforoclástica (McMindes \& Siedler, 1988).

Woods \& Wood (1982) analisando o C. botulinum, reportaram que o nitrito reduzia o teor de ATP intracelular, aumentava a concentração de piruvato e reduzia a produção de gás carbônico e hidrogênio pelas células. Eles postularam que o óxido nítrico formado através do nitrito reagia com o ferro não heme da ferredoxina para inibir a reação fosforoclástica.

Carpenter et al. (1987) analisando os efeitos do nitrito nos componentes do sistema fosforoclástico do $C$. botulinum in vivo e in vitro, concluíram que os efeitos inibitórios do nitrito foram, ao menos, em parte da inativação tanto da ferredoxina quanto da enzima piruvato-ferredoxina oxidoredutase (PFO). Esses autores concluíram que a inibição foi resultado da destruição dos centros de ferro-enxofre das enzimas, como a nitrogenase, a ferredoxina e a PFO, devido à formação de complexos ferroenxofre-óxido nítrico $(\mathrm{Fe}-\mathrm{S}-\mathrm{NO})$, concordando com a teoria proposta anos antes por 
Tompkin et al. (1978). Os sítios de ferro não heme são caracterizados pela presença de átomos de enxofre e é de interesse que complexos $\mathrm{Fe}-\mathrm{S}-\mathrm{NO}$ estejam supostamente ligados em aumentar a atividade do nitrito em sistemas aquecidos, particularmente na inibição do Clostridium (Moran et al., 1975). Tanto o nitrito quanto o óxido nítrico mostraram-se ser inibidores da atividade da nitrogenase, outra proteína que contém ferro não-heme em C. pasteurianum (Meyer, 1981).

Segundo O’Leary \& Solberg (1976), nos microrganismos anaeróbios como nos microrganismos aeróbios, o nitrito inibe outras enzimas. A perda completa da atividade da gliceraldeído-3-fosfato desidrogenase e a inibição substancial da aldolase foram observadas quando o crescimento do $C$. perfringens foi inibido pelo nitrito. Ambas as enzimas estavam envolvidas no metabolismo da glicose.

McMindes \& Siedler (1988) investigando os efeitos do nitrito e do óxido nítrico na enzima piruvato descarboxilase na levedura e na enzima piruvato:ferredoxina oxidoredutase no $C$. perfringens, verificaram que as concentrações de óxido nítrico, mas não de nitrito inibiram a descarboxilase da levedura e a PFO no C. perfringens.

\subsubsection{Utilização do eritorbato}

$\mathrm{O}$ ascorbato de sódio é sal sódico do ácido ascórbico (vitamina $\mathrm{C}$ ). $\mathrm{O}$ eritorbato de sódio é o sal sódico do ácido eritórbico ou ácido isoascórbico, que é um isômero do ácido ascórbico. O eritorbato e o ascorbato de sódio são utilizados em produtos cárneos com as funções principais de agir como seqüestrador de oxigênio, mudar o potencial redox do sistema e/ou reduzir a oxidação indesejável dos produtos. Pode também acelerar a formação e estabilizar a cor característica de carnes curadas com nitrito, reagir quimicamente com o nitrito e aumentar a síntese de óxido nítrico a partir do ácido nitroso (Tompkin et al., 1978).

A formação da cor é acelerada devido ao poder redutor do eritorbato, acelerando a redução do nitrito $\left(\mathrm{NO}_{2}\right)$ para óxido nítrico (NO). Os ascorbatos (incluindo o eritorbato) estabilizam a cor em carnes curadas quando ocorrem as seguintes condições:

- A quebra dos pigmentos curados começa com a dissociação do NO da molécula de nitrosomioglobina. Para manter o equilíbrio de massa, pode-se prever que esta 
dissociação será inibida pelo excesso de NO produzido pela reação entre o eritorbato e o nitrito residual presente na carne.

- A dissociação é favorecida pela presença de peróxidos provenientes da oxidação lipídica. A ação antioxidante do eritorbato previne a formação de peróxidos.

- A estabilidade da cor é melhor na ausência de oxigênio, sendo melhorada devido à ação seqüestradora de $\mathrm{O}_{2}$ dos ascorbatos (Ranken, 1981).

A partir do conhecimento de que o nitrito é responsável pela formação de nitrosaminas carcinogênicas, existe uma tendência em se diminuir o nitrito em produtos cárneos. Ainda de acordo com Ranken (1981), os ascorbatos reduzem em até 1/3 a necessidade de nitrito para formação de igual quantidade de óxido nítrico. A redução da concentração do nitrito residual em produtos cárneos tratados com ascorbatos levam a algumas implicações microbiológicas.

Segundo Shank (1962), o óxido nítrico produzido pela decomposição do nitrito tem pouco ou nenhum efeito antimicrobiano significativo nessas condições, bem como o ascorbato residual.

Em carnes cozidas curadas, a vida útil e a segurança microbiológica incluindo o Clostridium botulinum são influenciados pela formação de novas substâncias antimicrobianas obtidas através da interação dos constituintes da carne com o nitrito durante o processo de aquecimento (Ranken, 1981).

Segundo Tompkin et al. (1979), o eritorbato aumentou a eficácia antibotulínica do nitrito em produtos curados enlatados elaborados com carne suína. Isso ocorreu devido ao efeito seqüestrante do ascorbato e do eritorbato no cátion do ferro, por outro lado, elevados níveis de ascorbato demonstraram diminuir a eficiência do nitrito. Essa diminuição na inibição ocorreu, pois o eritorbato e o ascorbato ocasionaram uma rápida depleção do nitrito residual e o nitrito residual foi o fator primordial na inibição da atividade do botulismo.

\subsection{Produtos reestruturados}

No Brasil, o interesse por produtos de aves vem crescendo com o decorrer dos anos. Dentre esses produtos destacam-se os reestruturados, aja elaboração é dada pela 
desintegração do músculo através de processos mecânicos, nos quais os pedaços resultantes são então misturados, para posteriormente serem formatados em porções específicas. Nos Estados Unidos, o atributo textura, divide os produtos formatados em produtos seccionados e reestruturados. Nos produtos denominados seccionados, a textura deve ser mais próxima a de um músculo integral que nos produtos reestruturados (Keeton, 2001).

Os produtos reestruturados oferecem inúmeras vantagens por serem desossados, possuírem tamanho e formato apropriado, proporcionarem menor perda durante o cozimento e melhor aproveitamento dos músculos que seriam subutilizados, além de serem fáceis para aquecer e servir. A vida útil dos produtos empanados é aumentada principalmente pelo retardamento da oxidação e conseqüente aparecimento da rancidez, além de proteger a carne da desidratação e queima pelo frio durante o congelamento. Por outro lado, também existem suas limitações como, a baixa qualidade dos pedaços destinados ao processamento, que às vezes não podem ser melhorados, a exigência de mais equipamentos, de tecnologia de produção e boa manipulação para evitar a contaminação microbiológica, relacionando a maior tecnologia aplicada com maior necessidade de mão de obra especializada e capital (Lemos, 2000).

Os nuggets podem ser elaborados de uma grande variedade de carnes. Geralmente são processados com o músculo moído e refletem a preferência do consumidor local. Por exemplo, tanto no Brasil quanto nos Estados Unidos a carne branca é a preferida e possui maior valor de mercado, por outro lado na Ásia, a carne escura é a preferida e portanto considerada a de maior valor (Keeton, 2001).

A formulação dos nuggets inclui basicamente a carne do peito e a pele, esse músculo é geralmente escolhido devido a sua textura uniformemente macia e a coloração clara. Entretanto, outros cortes de aves, tais como, coxas e sobrecoxas, podem ser incorporados à formulação. A CMS também pode ser utilizada reduzindo os custos de produção e melhorando o sabor devido ao seu alto teor de gordura. Quando a carne clara é utilizada em combinação com a carne escura, utiliza-se normalmente a proporção de 70:30, respectivamente. O grande problema associado à utilização da carne escura na formulação é a susceptibilidade à oxidação devido ao alto teor de ferro e gordura 
presente nesse tipo de carne, além do comprometimento da coloração e da textura quando associada à proteína de soja. Para solucionar o problema com o escurecimento do produto, pode-se fazer uso de ingredientes como a proteína isolada de soja e caseinato de sódio (Owens, 2001).

O músculo é coberto por uma camada de tecido conectivo (epimísio), quando essa camada permanece intacta, pouca ou nenhuma extração de proteínas miofibrilares ocorre, por essa razão é necessário moer o músculo para ocorrer a redução das partículas e aumentar a área de contato para a extração protéica. Essa fase é fundamental no processamento, pois se não ocorrer uma extração de proteínas, os pedaços não irão se ligar até o processo de fritura, resultando em um produto com textura inconsistente. Após a moagem adiciona-se o sal e o tripolifosfato de sódio juntamente com a água para ocorrer a máxima extração protéica. A água pode ser adicionada na forma de gelo com o objetivo de abaixar a temperatura da carne, pois se ocorrer a elevação da temperatura, ocorrerá a desnaturação protéica resultando em um produto com pouca ligação com a água. Tal defeito no processamento também deverá ocorrer se a carne for extremamente moída e a massa for homogeneizada em excesso (Owens, 2001).

Segundo Barbut (2002b) no momento de formatar os nuggets é necessário que a temperatura da massa esteja entre $-3,3$ e $-2,2^{\circ} \mathrm{C}$, pois caso a temperatura não esteja baixa o suficiente a massa se torna mole e não adquire a forma desejada, ou então não consegue sair adequadamente da formatadora desfigurando o produto final. Além desses fatores, existe o problema de adesão do líquido de empanamento devido a umidade excessiva existente na sua superfície, por outro lado, se a temperatura da massa for extremamente baixa o produto pode se quebrar ao ser formatado levando a produção de nuggets defeituosos.

A etapa seguinte na elaboração dos nuggets é a fase do empanamento que pressupõe de três operações básicas: o pré enfarinhamento, a aplicação do "batter" (líquido de empanamento) e do "breading” (enfarinhamento).

O pré enfarinhamento tem como função melhorar a adesão por absorver a umidade superficial e/ou por funcionar como agente físico para a adesão do líquido de empanamento (Silveira, 1992). 
O líquido de empanamento é uma mistura líquida composta de água, farinha, amido, agentes de escurecimento, corantes, gomas, condimentos e flavorizantes. Tem um papel extremamente importante no processo de empanamento, pois é o principal determinante do ganho de peso, portanto, é de suma importância sua formulação e a eficiência do equipamento utilizado em sua aplicação. Existem basicamente dois tipos de "batter", um clássico e outro do tipo "tempura". Estes são escolhidos de acordo com as especificações dos produtos, sendo a diferença básica entre eles sua função, o primeiro tem a função de adesão enquanto o segundo apenas de cobertura, ou seja, apenas no primeiro processo é utilizada a farinha de cobertura (Lemos, 2000).

O "batter" tipo "tempura" utiliza fermento químico na sua formulação, portanto o produto final adquire uma aparência fofa, entretanto também é possível obter produtos crocantes utilizando o mesmo tipo de "batter", elevando a viscosidade do mesmo. A composição do líquido de empanamento influi tanto na qualidade sensorial (cor, maciez e crocância) quanto na espessura na cobertura, que interessa aos fabricantes por razões econômicas (Lemos, 2000; Silveira, 1992).

A farinha de cobertura é obtida a partir de cereais processados termicamente e apresenta como características consideradas importantes, a granulometria, textura, densidade, umidade, potencial de absorção de umidade e óleo, velocidade de escurecimento, cor e sabor. As farinhas que apresentam partículas de granulometria mais grosseira promovem um impacto visual maior, porém podem desprender-se durante o transporte ou manipulação; por outro lado, farinhas com granulometria muito fina apesar de promoverem uma cobertura uniforme, absorvem água muito rapidamente, ocasionando um rápido aumento da viscosidade de cobertura, resultando numa cobertura seca e rígida, depreciando sua aparência geral (Silveira, 1992).

A velocidade de escurecimento da farinha de cobertura depende da proporção de açúcares redutores usados na sua elaboração. Experimentos conduzidos no Centro de Tecnologia de Carne com peito de frango empanado evidenciaram que farinhas com maior granulometria absorviam mais óleo durante a pré-fritura. Verificou-se ainda que essas partículas eram mais porosas que as de menor granulometria, as quais apresentaram textura mais crocante e coloração mais atraente. Nesse mesmo 
experimento, observourse que as partes cárneas com pouca umidade superficial e temperatura variando de $0^{\circ} \mathrm{C}$ a $-2^{\circ} \mathrm{C}$, antes da aplicação da farinha de cobertura, apresentaram uma textura mais adequada (Silveira, 1992).

O processo de fritura é realizado na indústria com o auxílio de equipamentos contínuos e tem como objetivo realizar o cozimento parcial ou completo do produto pela sua imersão em óleo, além de preservar a forma do produto, assegurar a aderência da farinha de cobertura e proporcionar a textura típica crocante do produto (Barbut, 2002).

Segundo Owens (2001), o processo de fritura pode ser realizado por dois métodos, um no qual o produto é frito em uma única etapa e outro no qual o produto é frito em duas etapas. Quando se utiliza o primeiro método, o número de defeitos nos produtos tende a aumentar significativamente, pois diversos nuggets são fritos ao mesmo tempo, podendo grudar entre si e deste modo não atingir a temperatura adequada, principalmente nas superfícies onde houve o contato. Além disso, a adesão da farinha de cobertura pode ser comprometida com o aparecimento de falhas. Devido a esses problemas, grande parte da indústria processadora utiliza o método onde o produto é frito em duas fases. Na primeira fase, os nuggets são fritos em óleo a uma temperatura entre 179,4 a $198,8^{\circ} \mathrm{C}$ por 30 a 45 segundos e então removidos. Essa primeira etapa tem como objetivo fixar a farinha de cobertura e fritar a superfície da carne e do "batter/breading", reduzindo, deste modo, os defeitos nos produtos. Após essa etapa, os nuggets são novamente submergidos em óleo para a segunda fritura, cuja temperatura varia entre 165,5 a $179,4^{\circ} \mathrm{C}$ e o tempo varia dependendo do produto final desejado, tendo como objetivo o produto totalmente frito. Quando o produto está totalmente frito, as proteínas miofibrilares extraídas da superfície da carne formam fortes ligações resultando em um produto mais consistente.

Devido a preocupação com o consumo de frituras, indústrias alimentícias desenvolveram produtos que prometem minimizar esses problemas. A Kerry Ingredients desenvolveu um amido tipo pectina, que quando aplicado na superfície do produto reduz a absorção de óleo em 20 a 50\% durante a fritura, dependendo do produto e da cobertura utilizada. A Morton Foods desenvolveu uma emulsão de água, óleo, proteína e flavorizantes que quando pulverizada sobre os produtos já empanados, estes podem ser 
assados em forno infravermelho a $900^{\circ} \mathrm{C}$ por 40 a 60 segundos mantendo a textura e a coloração desejada de produtos fritos (Keeton, 2001).

Após o processo de fritura ter sido completado, os produtos são congelados e embalados. Como esses produtos são fritos e congelados antes da distribuição, o crescimento bacteriano não é um fator limitante na vida útil, ao contrário da desidratação e da oxidação lipídica, que podem ter seus efeitos minimizados através da utilização de uma boa embalagem e de um tipo de óleo que contenha antioxidantes (Barbut, 2002b).

\subsection{Capacidade de Emulsificação (CE)}

Teoricamente, emulsão é um sistema de duas fases líquidas imiscíveis, nas quais uma se encontra dispersa na outra sob forma de gotículas (Pardi et al., 1994). Na emulsão cárnea, as gotículas de gordura ficam dispersas em meio aquoso contendo proteínas solúveis, outros componentes musculares e tecido conjuntivo. Cada gotícula de gordura é recoberta por uma fina camada de proteína solúvel, que funciona como agente emulsionante liberada no meio aquoso a partir das fibras musculares. Portanto, essas proteínas são as responsáveis pela ligação da água e pela estabilização da gordura. A variação na capacidade do tecido animal em emulsificar e reter a gordura na emulsão se dão em função da quantidade de proteínas solúveis em sal potencialmente disponíveis. A capacidade total dos componentes cárneos em estabilizar a gordura é definida como a capacidade de emulsificação. Tal capacidade é maior em alguns ingredientes que os outros devido às diferenças nos teores de colágeno e proteínas miofibrilares (Barbut, 2002b).

O teste de capacidade de emulsificação é um dos testes mais populares utilizados na indústria cárnea. De acordo com esse teste, óleo líquido (geralmente óleo vegetal) é gradualmente adicionado a um homogeneizador com alta velocidade até a quebra da emulsão. A quebra pode ser visualmente observada ou medida pela mudança na condutividade elétrica na massa. Essa condutividade pode ser medida, pois no ponto de quebra, a condutividade na fase contínua aquosa (água e sal) é significativamente diminuída quando a gordura não é mais confundida com pequenos glóbulos (Haq et al., 1973). 
Lesiow \& Skrabkblotnicka (1988) verificaram a capacidade de emulsificação e a estabilidade da emulsão em peitos de pato congelados e observaram que os dois aspectos estudados diminuíram com o aumento do período de estocagem, a principal explicação apontada pelos pesquisadores foi a desnaturação das células ocorrida no processo de congelamento.

Froning \& Neelakantan (1971) observaram que o músculo do peito de frango no estado de pré rigor tinha uma capacidade de emulsificação e uma estabilidade de emulsão significativamente melhor que a encontrada no músculo pós rigor e que existe uma alta correlação entre o pH e a capacidade de emulsificação.

\subsection{Capacidade de Retenção de Água (CRA)}

Capacidade de retenção de água (CRA) pode ser definida como um termo utilizado para descrever a habilidade do músculo em se ligar à água sob diversas condições, ou seja, é a capacidade da carne em reter água mesmo sob a aplicação de uma força (Trout, 1988).

As características de qualidade sensorial da carne, tais como, maciez, textura, gotejamento no congelamento e descongelamento e o encurtamento durante o cozimento dependem do grau de hidratação das proteínas musculares. Podendo afetar deste modo não só o valor econômico da carne, como também sua aparência e a atratividade pelo consumidor (Wierbicki \& Deatherage, 1958).

A CRA é um atributo essencialmente importante, especialmente em produtos cárneos que serão cozidos novamente. A carne em geral, possui aproximadamente $70 \%$ de água, a maior parte dessa água não está firmemente ligada pelas proteínas. Quando essa carne é cozida, uma grande proporção dessa água presente é perdida na forma de vapor, se essa carne for cozida duas vezes, uma na indústria e outra pelo consumidor para garantir o cozimento total a uma temperatura adequada, pode ocorrer a diminuição da qualidade da carne em função da quantidade de água perdida (Baker \& Bruce, 1995).

Aproximadamente $95 \%$ da água no músculo é classificada como água livre, que são moléculas que se encontram fracamente ligadas entre si e podem migrar entre as estruturas celulares, as quais são mantidas pela membrana celular. O restante da água 
(aproximadamente 5\%) é classificada como água quimicamente ligada que está firmemente associada às proteínas musculares (Trout, 1988).

O músculo contém água de hidratação, água ligada eletrostaticamente, água absorvida fisicamente e fortemente ligada às proteínas por forças secundárias como, indução dipolo-dipolo, pontes de hidrogênio e capilaridade. Para fins de determinação da CRA é de interesse a água livre, pois quase todas as modificações observadas na capacidade de retenção de água são devidas às modificações experimentadas pela água fracamente ligada. (Wierbicki \& Deatherage, 1958).

As condições ante mortem tais como genética e transporte e condições post mortem como resfriamento e estocagem influenciam a quantidade do gotejamento (Baker \& Bruce, 1995).

A água no tecido muscular está localizada no interior dos filamentos, nos espaços entre os filamentos e intrafibrilares (espaço sarcoplasmático) e nos espaços extracelulares. Como as miofibrilas ocupam aproximadamente $70 \%$ do músculo, a maior parte da água do tecido está localizado nas miofibrilas, entretanto mudanças na capacidade de retenção da água no músculo serão em grande parte, devido a variações na imobilização da quantidade de água nos espaços entre os filamentos e nos filamentos propriamente ditos (Hamm, 1986)

A imobilização da água no tecido é aparentemente determinada pelo arranjo espacial das moléculas de proteínas miofibrilares (principalmente a miosina) ou dos filamentos. Se a atração entre as moléculas adjacentes ou filamentos diminui, causado pelo aumento da repulsão eletrostática entre cargas similares de grupos protéicos ou pelo enfraquecimento das pontes de hidrogênio, alonga-se a cadeia de proteínas, a intumescência aumenta, e mais água pode ser imobilizada dentro de grandes malhas, aumentando a capacidade de retenção de água (Hamm, 1986).

\subsection{Critério de avaliação dos consumidores}

A Associação Nacional de Empresas de Pesquisa - ANEP, criou um sistema denominado Critério de Classificação Econômica Brasil. Este foi desenvolvido visando atender a dois objetivos fundamentais, o primeiro deles foi montar um sistema de 
pontuação da população que fosse um eficiente estimador da sua capacidade de consumo e o segundo foi estabelecer cortes na distribuição dessa população que permitissem discriminar os grandes grupos consumidores (ANEP, 2001).

Ainda de acordo com a ANEP (2001), o estudo que fundamentou o desenvolvimento desse critério foi inicialmente realizado com base no banco de dados do Levantamento Sócio-Econômico - LSE de 1993 do IBOPE, que pesquisou vinte mil domicílios, constituindo uma amostra representativa da população urbana moradora em municípios acima de vinte mil habitantes. A partir desse banco de dados foi construído o sistema de pontos e de itens de consumo. Posteriormente, dada a nova realidade econômica a partir do Plano Real e baseada em uma nova amostra de dez mil domicílios (LSE/96), foi feita uma reavaliação do sistema de pontos e um reexame de classes.

Segundo a ANEP (2001), o Brasil está dividido em sete classes econômicas sendo a primeira definida como classe A1 na qual se encaixam as famílias cujas rendas mensais são superiores ou iguais a $\mathrm{R} \$ 5555,00$. A segunda classe é denominada como A2, nessa situam-se famílias com renda mensal entre $\mathrm{R} \$ 2944,00$ a 5554,00. A terceira e quarta classe são a B1 e a B2 cujas rendas familiares mensais variam de $\mathrm{R} \$ 1771,00$ a 2943,00 e R\$1065,00 a 1770,00 respectivamente; seguida das classes C e D cujas rendas familiares mensais variam de $\mathrm{R} \$ 497,00$ a 1064,00 para a $\mathrm{C}$ e $\mathrm{R} \$ 263,00$ a 496,00 para a $\mathrm{D}$ e por último a classe E cuja família possui renda mensal de até $\mathrm{R} \$ 262,00$.

Os sete grupos propostos pela ANEP (2001) foram caracterizados em cima do cálculo da porcentagem sobre a posse de certos bens, como televisão em cores, rádio, banheiro, automóvel, empregada mensalista, aspirador de pó, máquina de lavar, vídeo cassete, geladeira, freezer e grau de instrução do chefe da família. Quanto maior a porcentagem relacionada ao item especificado, maior a classificação econômica.

A distribuição das classes econômicas em função da região do país pode ser vista na Tabela 1. 
Tabela 1. Distribuição das classes econômicas por região.

\begin{tabular}{ccccc}
\hline Classe & Norte/Nordeste & Sudeste & Sul & Centro Oeste \\
Econômica & $\%$ & $\%$ & $\%$ & $\%$ \\
\hline A1 & 1 & 1 & 1 & 1 \\
A2 & 3 & 4 & 5 & 4 \\
B1 & 3 & 8 & 7 & 8 \\
B2 & 6 & 14 & 13 & 10 \\
C & 20 & 35 & 35 & 28 \\
D & 37 & 32 & 30 & 38 \\
E & 30 & 6 & 8 & 13 \\
\hline
\end{tabular}

\subsection{Análise sensorial: teste de consumidor}

A preferência pode ser definida como a expressão do grau gostar, a escolha de uma amostra em relação à outra e/ou o contínuo psicológico do afetivo (percepção do agradável até o desagradável) através dos quais baseiam a escolha (Dutcosky, 1996).

Grande parte da dieta humana consiste de carne e produtos cárneos. A preferência por esses produtos é apenas uma parte que justifica sua escolha. Isso implica que tanto a preferência quanto a escolha são afetadas por fatores endógenos, como a hereditariedade, o sexo, a idade, a atividade e fatores exógenos como a cultura, a sociedade e a economia. A preferência não pode ser considerada um bom indicativo para predizer a frequiência do consumo, já que este é afetado tanto pelo comportamento quanto pelos valores individuais, bem como pelos fatores culturais. Os atributos do produto são considerados decisivos na preferência de um produto sobre o outro (Risvik, 1994). 


\section{MATERIAL E MÉTODOS}

\subsection{Matéria-prima: CMS}

Foram realizadas três extrações de CMS de galinhas poedeiras e matrizes, nos seguintes períodos: outubro/2000, janeiro/2001 e março/2001. Utilizou-se em torno de $150 \mathrm{~kg}$ de cada galinha, correspondendo a aproximadamente 45 cabeças de matrizes (aprox. 3,3Kg / carcaça) e 110 de poedeiras (aprox. 1,3Kg / carcaça), em cada extração. Estas galinhas foram cedidas por um abatedouro do interior do Estado de São Paulo e foram recebidas congeladas e embaladas com miúdos, pés e cabeças. Após descongelamento, as galinhas foram desembaladas e os miúdos descartados. Os filés de peito com pele foram separados e congelados para a elaboração de um produto reestruturado e empanado. Todo o restante da carcaça foi utilizado para obtenção de CMS.

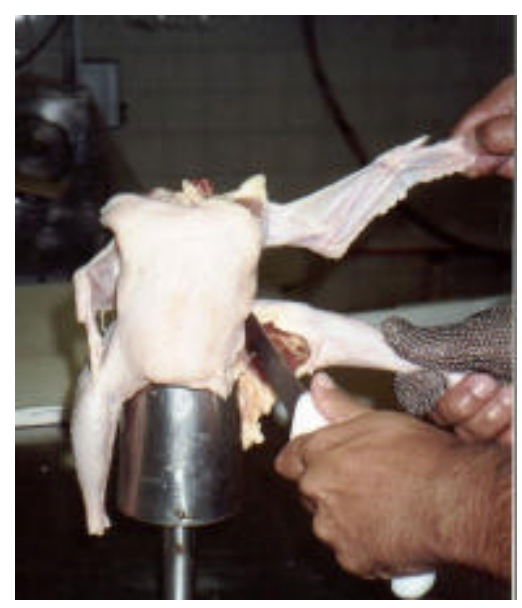

Figura 3 - Galinha poedeira.

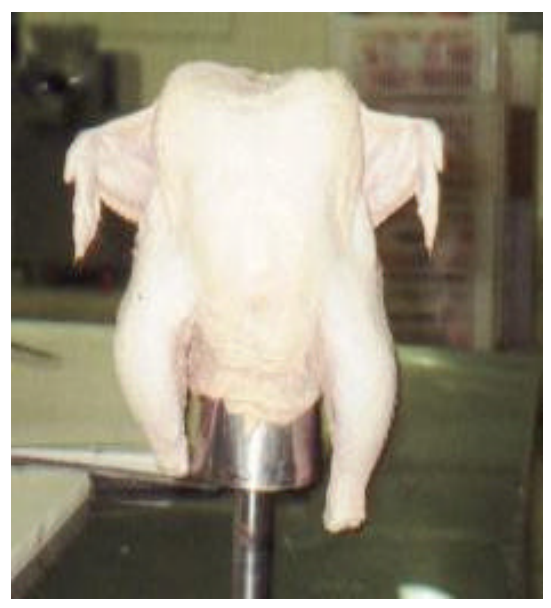

Figura 4 - Galinha matriz. 


\subsubsection{Extração da CMS}

Após a separação dos filés de peito, as carcaças previamente cortadas foram novamente congeladas, em câmara a $-10^{\circ} \mathrm{C}$. A extração foi realizada em extratora POSS, modelo PDE 1000. Todas as CMSs foram homogeneizadas, embaladas em sacos de polietileno com aproximadamente $400 \mathrm{~g}$ de amostra e então congeladas a $-18^{\circ} \mathrm{C}$ até a realização das análises.

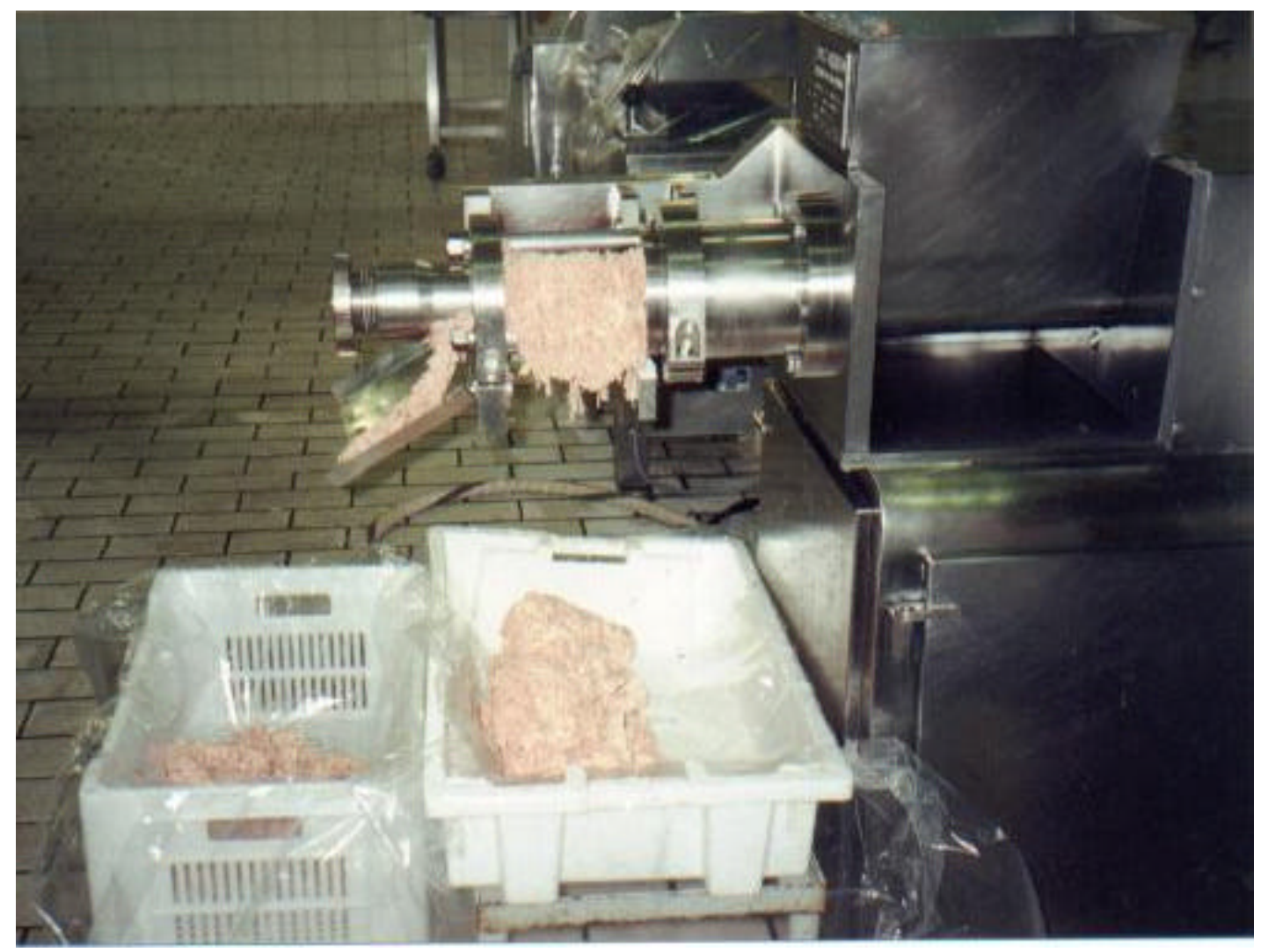

Figura 5 - Extração da carne mecanicamente separada. 


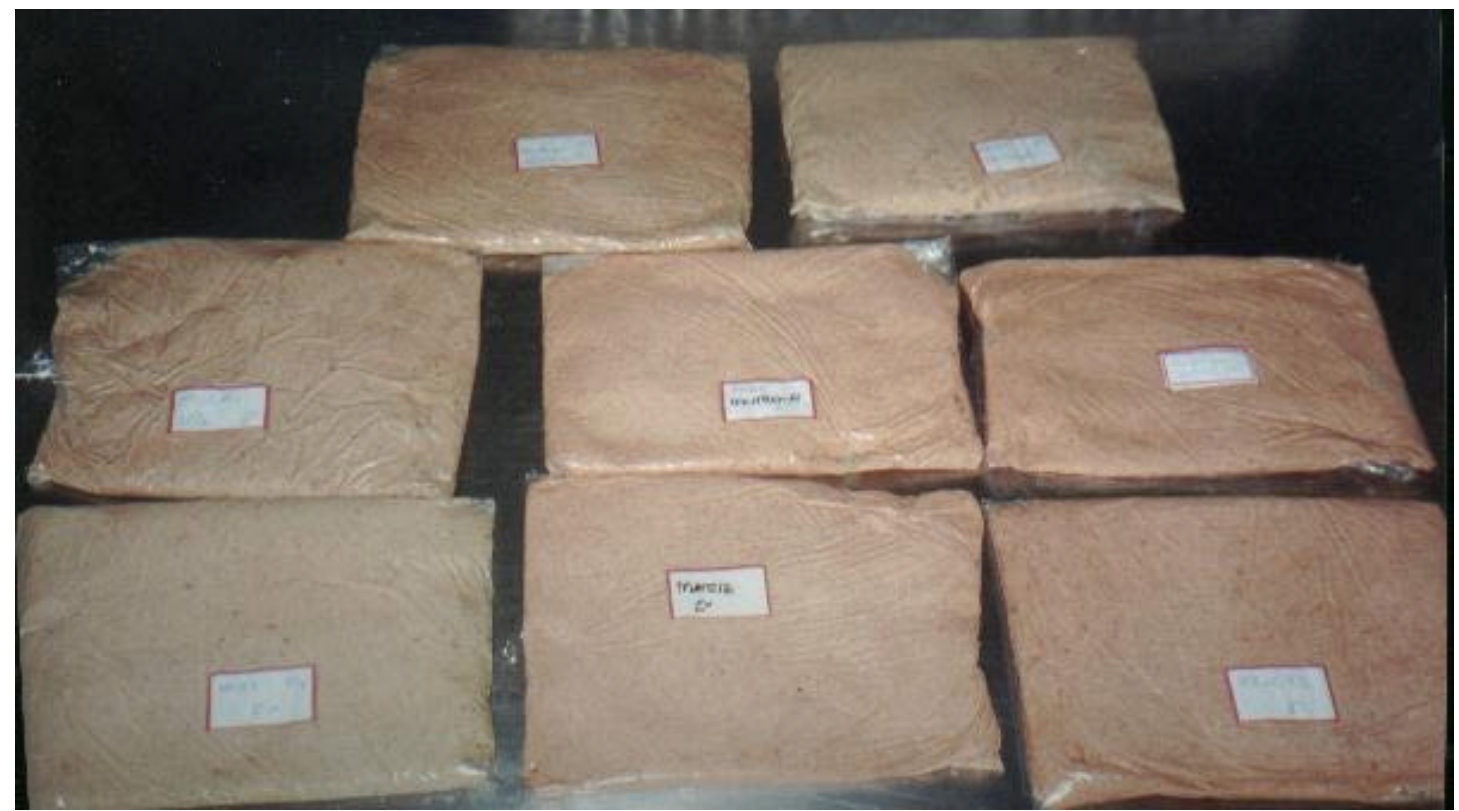

Figura 6 - Carnes mecanicamente separadas embaladas em sacos de polietileno.

\subsubsection{Descongelamento das amostras}

As amostras foram descongeladas em câmaras de refrigeração com temperatura de $2^{\circ} \mathrm{C}\left( \pm 2^{\circ} \mathrm{C}\right)$ por aproximadamente 12 horas. Após esse período, as amostras foram conduzidas para as análises físico-químicas e microbiológicas.

\subsubsection{Determinação de pH}

Medido em pHmetro DIGIMED DM-20 com eletrodo de punção diretamente na amostra.

\subsubsection{Caracterização microbiológica}

De cada amostra de CMS analisada contendo aproximadamente 400 gramas, foram retirados 25 gramas e diluídos em $225 \mathrm{~mL}$ de água salina peptonada tamponada. A primeira diluição foi acompanhada de uma adequada homogeneização no "stomacher" (Seward - Medical London).

Como o grupo de microrganismos estudado compreendeu a contagem total de bactérias mesófilas e psicrotróficas aeróbias, Salmonella spp., Pseudomonas, 
Escherichia coli, Staphylococcus aureus e Clostridium perfringens, a diluição inicial realizada para a análise de Salmonella spp., foi a mesma utilizada para as demais análises.

Exceto para as análises de Pseudomonas e Staphylococcus aureus, que seguiu metodologia segundo Mead \& Adams (1977), e Silva (1994), respectivamente, todas as demais análises realizadas foram de acordo com a metodologia de Vanderzant \& Splittstoesser (1992).

O limite de detecção permitido pelas análises microbiológicas para as análises de Pseudomonas, S. aureus, Clostridium perfringens, bactérias mesófilas e psicrotróficas aeróbias foi de $10 \mathrm{UFC/g}$, e para a análise de $E$. coli foi <3 NMP/g.

\subsubsection{Pesquisa de Salmonella spp.}

Foi retirada uma unidade analítica de 25 gramas e transferida para uma embalagem previamente esterilizada e tarada. Adicionou-se $225 \mathrm{~mL}$ de caldo de préenriquecimento (água peptonada tamponada) (Oxoid CM510) para posterior homogeneização. As embalagens foram incubadas a $35^{\circ} \mathrm{C} / 18-24$ horas, de modo a promover o enriquecimento seletivo em Caldo base Tetrationato (Oxoid CM29) (1,0mL de inóculo em $10 \mathrm{~mL}$ de caldo) e Caldo Rappaport-Vassiladis (Oxoid CM669) (0,1mL de inóculo em $10 \mathrm{~mL}$ de caldo), incubados a $43^{\circ} \mathrm{C} / 24$ horas. A partir destes estriourse uma alçada tanto do caldo Tetrationato quanto do caldo Rappaport-Vassiladis em placas de Ágar Entérico de Hektoen (Oxoid CM419) e Ágar Xilose Lisina Desoxiciolato (Oxoid CM469), sendo incubadas a $35^{\circ} \mathrm{C} / 24$ horas.

As colônias típicas de cada placa partiram para os testes confirmativos através de provas bioquímicas e sorológicas. Essas colônias foram semeadas em tubos com Ágar Tríplice Açúcar Ferro (Oxoid CM277), Ágar Lisina Ferro (Oxoid CM381) e Ágar Base Uréia (Oxoid-CM53) e incubados a $35^{\circ} \mathrm{C} / 24$ horas. Dependendo do resultado observado que se dá de acordo com a viragem da cor do meio, segue-se para as provas sorológicas. No presente estudo não foi necessária a realização das provas sorológicas. 


\subsubsection{Contagem total de bactérias aeróbias mesófilas e psicrotróficas}

Após o preparo das amostras e das diluições seriadas selecionourse as diluições adequadas e inoculou-se $1,0 \mathrm{~mL}$ de cada diluição em placas de Petri separadas, estéreis e vazias. O plaqueamento foi feito em duplicata tanto para mesófilos quanto para psicrotróficos. Verteu-se nas placas inoculadas o Ágar Padrão para Contagem (Oxoid CM463), previamente fundido e resfriado a aproximadamente $45^{\circ} \mathrm{C}$. Após a completa solidificação do meio, incubou-se as placas de bactérias mesófilas a $37^{\circ} \mathrm{C}$ por 48 horas e as placas referentes a contagem de bactérias psicrotróficas foram incubadas a $22^{\circ} \mathrm{C}$ por 72 horas. Selecionou-se e contoutse as placas com 30 a 300 colônias. O número de unidades formadoras de colônias (UFC) por grama da amostra foi calculado com a média aritmética da contagem obtida em cada uma das placas da duplicata através da multiplicação do número de colônias pelo inverso da diluição inoculada.

\subsubsection{Contagem de Staphylococcus aureus}

Selecionou-se as diluições adequadas das amostras e inoculou-se na superfície de placas de Ágar Baird-Parker (Oxoid CM275) com manitol, sal $(\mathrm{NaCl})$ e gema de ovo, previamente preparadas e incubou-se a $37^{\circ} \mathrm{C}$ por 48 horas. Foi feita a contagem de colônias circulares, lisas, com bordas perfeitas, convexas, de coloração amarela escuro com halo transparente decorrente da reação da lecitina. Selecionou-se de 3 a 5 colônias e transferiu-se cada colônia para um tubo com Caldo Infusão Cérebro Coração (Difco 0037-17) sendo incubados a $35^{\circ} \mathrm{C}$ por 24 horas para posterior confirmação através do Teste de coagulase em plasma de coelho (Laborclin - 570204).

Para o Teste de coagulase, transferiu-se $0,1 \mathrm{~mL}$ de cada cultura obtida em Caldo Infusão Cérebro Coração para um tubo de 10x100mm. Adicionou-se ao $0,1 \mathrm{~mL}$ de cultura 0,2mL de Coagulase Plasma-EDTA (plasma de coelho com EDTA) e misturour se com movimentos de rotação. Incubou-se em banho-maria a $37^{\circ} \mathrm{C}$ por até 4 horas e observou se houve formação de coágulos. 


\subsubsection{Contagem de Escherichia. Coli}

Utilizourse o Caldo Fluorocult Laurilsulfato (LST-MUG) (Merck-112588). Semeou-se quatro séries de três tubos em LST-MUG contendo tubos de Durhan. Foi feita a incubação a $35^{\circ} \mathrm{C}$ por $24 / 48$ horas, após essa período foram tomados todos os tubos de LST-MUG com crescimento em 24 ou 48 horas, com ou sem produção de gás e observou-se sob lâmpada de luz ultravioleta (3 a 6w), ondas longas (365nm), numa cabine escura. Foram considerados positivos todos os tubos que apresentaram fluorescência azul, confirmativa da presença de E. coli. O número de tubos positivos foi anotado e determinou-se o número mais provável (NMP) em uma tabela adequada às diluições utilizadas.

\subsubsection{Contagem de Clostridium perfringens}

As diluições selecionadas foram semeadas em placas com Triptose Sulfito Cicloserina (Oxoid-CM587) com gema de ovo suplementado com antibiótico sulfato de polimixina e kanamicina (Oxoid-SR88) previamente preparadas. Foi realizado um “overlay” para gerar as condições de anaerobiose exigida pelo C. perfringens.

Após a completa solidificação da sobrecamada incubourse as placas a $37^{\circ} \mathrm{C} / 18$ 20 horas em atmosfera anaeróbia obtida através da utilização de jarros com gerador de anaerobiose. Foram contadas as colônias negras típicas. Três a cinco colônias foram selecionadas e transferidas para o Caldo Cérebro Coração (Difco - 0037-17), os quais foram incubados a $37^{\circ} \mathrm{C} / 24$ horas para a realização das provas bioquímicas nos seguintes meios: meio lactose gelatina (teste de fermentação da lactose e hidrólise da gelatina), meio de leite ferro (teste da coagulação tempestuosa do leite), Ágar nitrato motilidade (teste de redução do nitrato e teste de motilidade).

\subsubsection{Contagem de Pseudomonas spp.}

Selecionou-se as diluições adequadas que foram inoculadas em placas de Ágar Base Pseudomonas (Oxoid CM559) com suplemento seletivo cloranfenicol (Oxoid SR102 ou SR103), previamente preparadas. Espalhou-se o inóculo com o auxílio de uma alça de Drigaslski de modo que todo líquido fosse absorvido pelo meio de cultura. Após 
a secagem completa das placas, estas foram incubadas a $25^{\circ} \mathrm{C} / 72$ horas, para o procedimento de contagem das colônias. As colônias típicas possuem coloração branca leitosa.

\subsubsection{Pré-cura com nitrito e eritorbato de sódio}

Após sua obtenção, as CMSs de cada galinha foram separadas em três partes de 9,5 Kg. Cada parte foi misturada com 0,5Kg de água destilada, onde os aditivos da précura foram previamente dissolvidos. Esta água foi utilizada para garantir melhor distribuição dos aditivos nas CMSs. No tratamento controle adicionou-se apenas água pura. No tratamento com nitrito adicionou-se $1,5 \mathrm{~g}$ de nitrito de sódio, equivalente a 150ppm. No outro tratamento adicionourse $1,5 \mathrm{~g}$ de nitrito e 5,0g de eritorbato de sódio, equivalente a 500ppm de eritorbato. A água com os aditivos previamente dissolvidos foi incorporada às CMSs pela homogeneização em misturadeira CAF, modelo M-60, durante três minutos. Após a homogeneização, cada tratamento foi embalado em sacos de polietileno com aproximadamente $400 \mathrm{~g}$, sendo em seguida congelados e estocados a $-18^{\circ} \mathrm{C}\left( \pm 1^{\circ} \mathrm{C}\right)$ durante 99 dias.

\subsubsection{Delineamento experimental}

A pré-cura das CMSs foi realizada de acordo com o seguinte delineamento experimental, num total de 6 (seis) tratamentos:

- Matriz controle - MC: CMS de galinha matriz onde não foi adicionado nenhum aditivo;

- Matriz nitrito - MN: CMS de galinha matriz pré-curada com nitrito de sódio (150ppm);

- Matriz eritorbato - ME: CMS de galinha matriz pré-curada com nitrito de sódio (150ppm) e eritorbato de sódio (500ppm).

- Poedeira controle - PC: CMS de galinha poedeira onde não foi adicionado nenhum aditivo;

- Poedeira nitrito - PN: CMS de galinha poedeira pré-curada com nitrito de sódio (150ppm); 
- Poedeira eritorbato - PE: CMS de galinha poedeira pré-curada com nitrito de sódio (150ppm) e eritorbato de sódio (500ppm).

Todos os tratamentos foram replicados três vezes, uma vez em cada uma das três diferentes extrações das CMSs.

\subsubsection{Avaliação da estabilidade microbiológica}

As primeiras análises microbiológicas foram realizadas no dia seguinte à extração, sendo repetidas a cada 14 dias até 99 dias de estocagem, num total de 8 períodos, a saber: 1, 15, 29, 43, 57, 71, 85 e 99 dias. No dia seguinte a extração, as amostras estocadas refrigeradas foram analisadas através da contagem de microrganismos psicrotróficos e mesófilos aeróbios, Staphylococccus aureus, Clostridium perfringens, Salmonella spp., Pseudomonas spp. e E. coli. No $15^{\circ}, 29^{\circ}, 43^{\circ}$, $57^{\circ}, 71^{\circ}, 85^{\circ}$ foi realizada apenas a contagem de microrganismos psicrotróficos aeróbios. No último dia de estocagem $\left(99^{\circ}\right)$ repetiram-se todas as análises microbiológicas, de modo a avaliar o perfil microbiológico das amostras submetidas aos tratamentos no decorrer deste período.

As análises microbiológicas seguiram metodologia segundo Vanderzant \& Splittstoesser (1992), exceto as análises de Pseudomonas que seguiu metodologia segundo Mead \& Adams (1977) e Staphylococccus aureus que foi realizada segundo Silva (1994).

\subsubsection{Análise estatística}

Para a avaliação e interpretação dos resultados procedeutse a análise de variância, utilizando o programa STATISTICA, com o objetivo de verificar se houve ou não diferença entre os tratamentos aplicados e a interação entre tempo e tratamento.

\subsection{Matéria-prima: nugget}

Os filés de peito e as peles de galinhas foram desossados manualmente a partir das carcaças de galinhas matrizes pesadas (aprox. 3,5kg/carcaça) e poedeiras comerciais (aprox. 1,2kg/carcaça). O restante destas carcaças foi utilizado para extração de carne 
mecanicamente separada (CMS). Os filés de peito e as peles dos frangos foram desossados a partir de cortes de peito com osso. Todas as desossas foram replicadas três vezes. Toda matéria-prima, ou seja, as galinhas de descarte e os cortes de peito com osso foram doados por um abatedouro do interior do Estado de São Paulo.

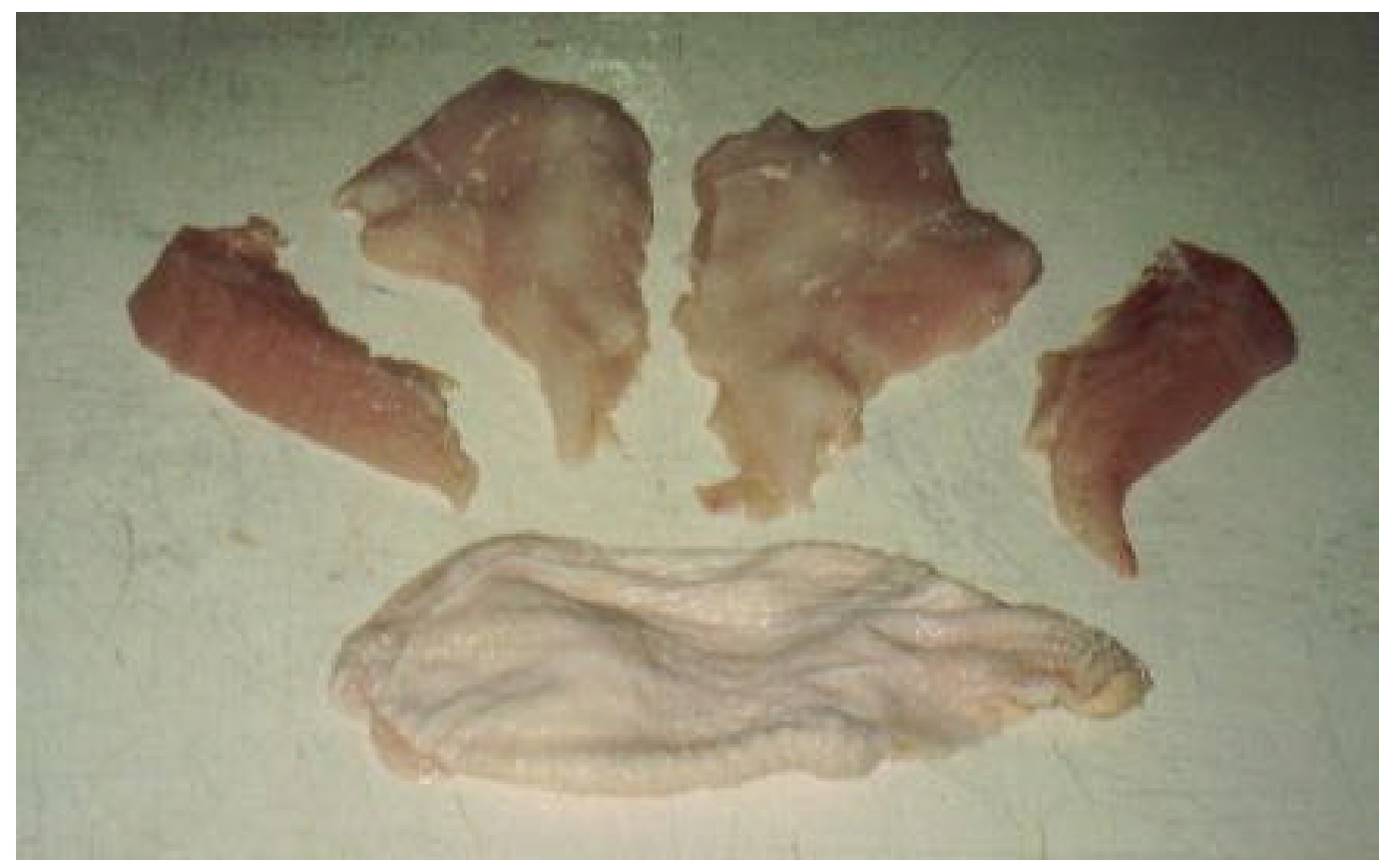

Figura 7 - Matéria-prima utilizada para elaboração dos nuggets (filés de peito e pele).

\subsubsection{Caracterização dos filés de peito}

\subsubsection{Composição centesimal}

A metodologia oficial da AOAC (Cunnif, 1998) foi utilizada para determinação de proteína, gordura, umidade e cinzas.

\subsubsection{Determinação de $\mathrm{pH}$}

Medido em pHmetro DIGIMED DM-20 com eletrodo de punção diretamente na amostra. 


\subsubsection{Capacidade de Retenção de Água (CRA)}

Essa análise foi determinada utilizando metodologia descrita por Grau \& Hamm (1953) modificado por Hoffmann et al. (1982), a qual baseia-se na pesagem acurada de 0,5g de carne na balança analítica em papel filtro, que foram posteriormente colocados entre duas placas de plexiglass e prensados por 2 minutos a 500 p.i.s. Devido à pressão o material cárneo foi comprimido formando um filme circular (filme cárneo), enquanto que a água expelida foi absorvida pelo papel de filtro formando uma área circular de coloração avermelhada (área da água livre). As áreas foram medidas com um planímetro e a porcentagem de água livre calculada pela razão da área do filme cárneo sobre a área total. Todas as amostras foram retiradas de porções cárneas descongeladas 24 horas antes das análises, sendo realizadas seis repetições por amostra em cada extração.

\subsubsection{Capacidade de Emulsificação (CE)}

Utilizourse uma metodologia baseada em Swift et al. (1961) e modificada para este trabalho. $25 \mathrm{~g}$ de amostra foram homogeneizadas em $100 \mathrm{ml}$ de solução de $\mathrm{NaCl} 1 \mathrm{M}$ durante 2 minutos em homogeneizador Sorvall. Em um béquer pesou-se 2,5g desta solução inicial e adicionourse $20 \mathrm{~mL}$ de água destilada e $10 \mathrm{~mL}$ de óleo de soja. Em seguida procedeurse o emulsionamento em aparelho Ultra-Turrax T25 durante 15 segundos, e então iniciou-se a adição de óleo até a quebra da emulsão. O ponto de quebra da emulsão foi detectado visualmente pela redução drástica da viscosidade. $\mathrm{O}$ fluxo de óleo adicionado situourse entre 12 a $16 \mathrm{ml}$ de óleo por minuto. Esta análise foi realizada na segunda e terceira replicação do experimento, sendo feitas 6 repetições da análise para cada amostra, em cada replicação.

\subsubsection{Processamento dos produtos empanados tipo nuggets}

Foram elaborados três tratamentos diferentes, ou seja: um de frango, um de galinha matriz e um terceiro de galinha poedeira. Em cada tratamento utilizou-se o filé de peito e a pele da respectiva ave. Todos os processamentos foram realizados em triplicata. A formulação padrão está apresentada na Tabela 2. Os filés de peito foram congelados separadamente e moídos em moedor HERMANN, modelo 106, em discos de 
$10 \mathrm{~mm}$, enquanto a pele foi congelada e moída em discos de $2 \mathrm{~mm}$. Após o processo de moagem, a carne foi misturada em misturadeira CAF, modelo M-60 juntamente com os demais ingredientes, por um período de 5 minutos. Em seguida a massa foi moldada na forma final dos nuggets em formadora HOLLYMATIC, modelo 54. Após a moldagem, os nuggets seguiram para a linha de empanamento e pré-fritura (marca STEIN), que contou com as seguintes etapas: primeiramente os nuggets foram passados em "prédust", marca KERRY PDA66-TC para serem em seguida imersos em "batter" (KERRY ABB81), dissolvido na proporção 1:1,6 (pó:água). Para cobertura final utilizou-se CLASSIC CRUMB 4034, também da KERRY. Os nuggets sofreram uma pré-fritura em gordura vegetal (marca CEVAL, tipo CUKIN FRY) a $180^{\circ} \mathrm{C}$ durante aproximadamente um minuto. Após a pré-fritura, os nuggets foram embalados, congelados e armazenados $\mathrm{a}-18^{\circ} \mathrm{C}$, para posterior avaliação sensorial.

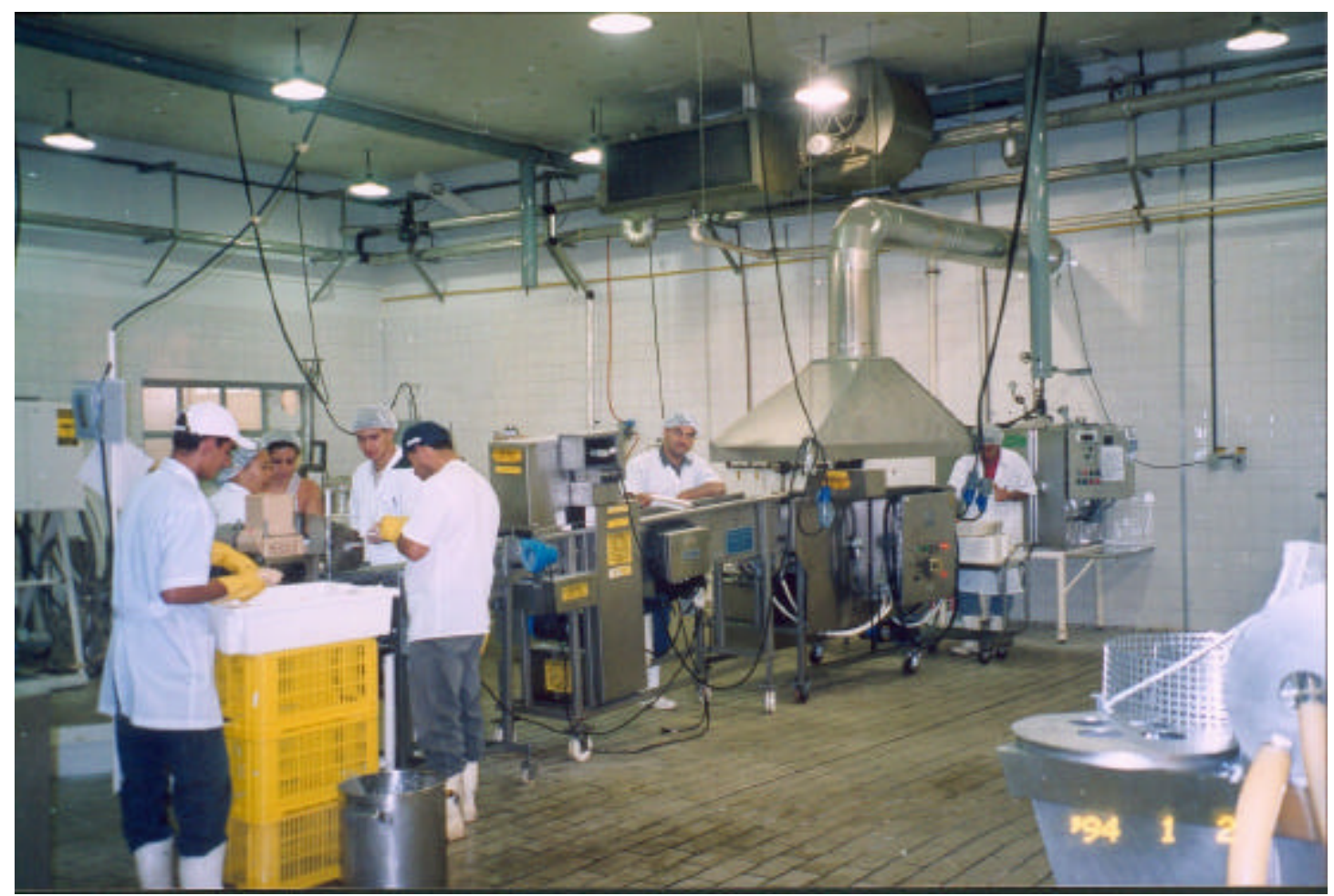

Figura 8 - Linha de empanamento. 


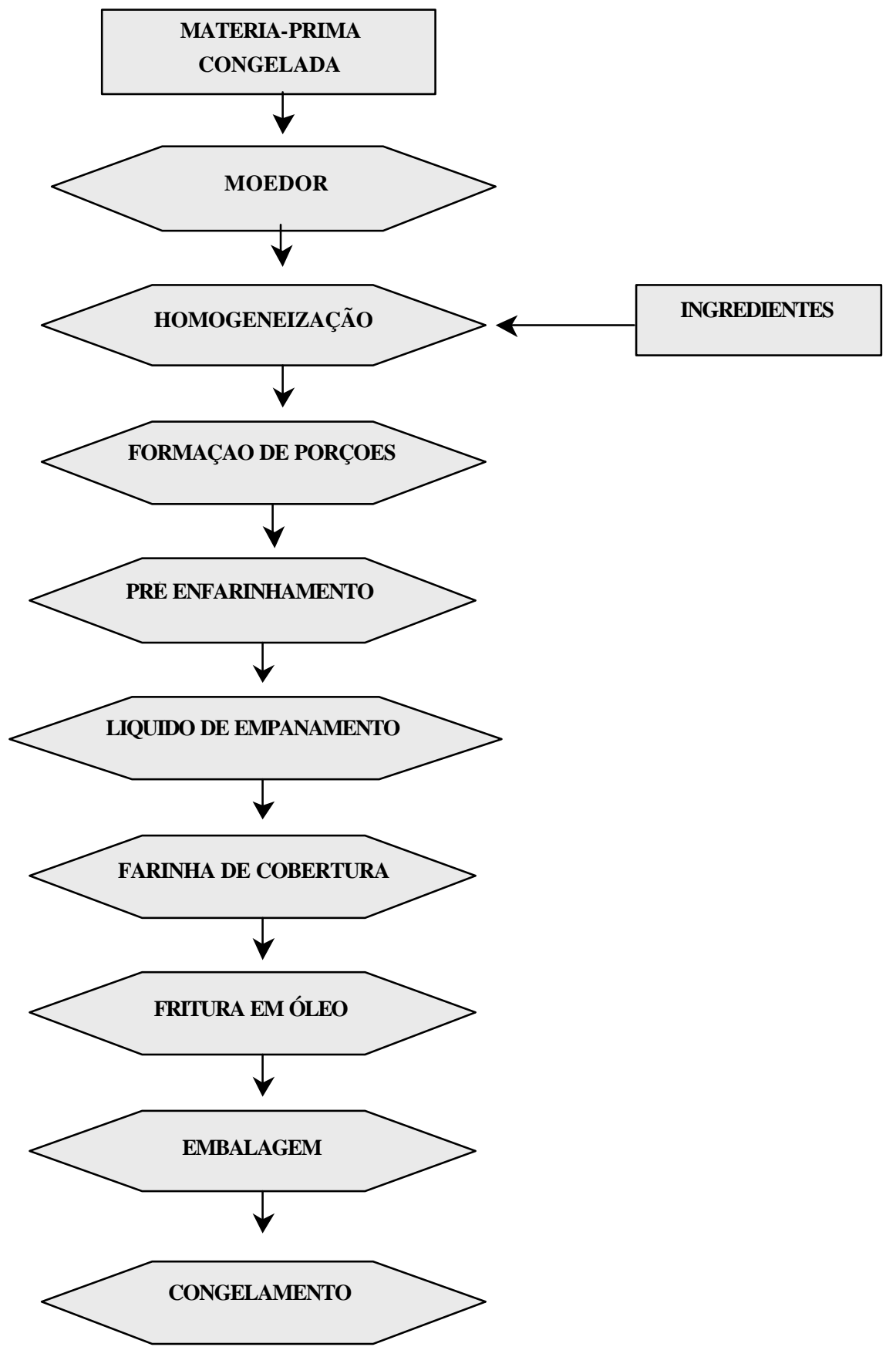

Figura 9- Fluxograma do processo de obtenção dos nuggets. 
Tabela 2. Formulação utilizada na fabricação dos nuggets.

\begin{tabular}{lcc}
\hline Ingredientes & $\%$ & Peso $(\mathrm{g})$ \\
\hline Peito & 78,00 & 7.800 \\
Pele & 10,00 & 1.000 \\
Água & 8,02 & 802 \\
Sal & 1,10 & 110 \\
Proteína de soja & 1,00 & 100 \\
Fosfato & 0,35 & 35 \\
Cebola em pó & 0,15 & 15 \\
Alho em pó & 0,10 & 10 \\
Pimenta branca & 0,03 & 3 \\
Açúcar & 0,20 & 20 \\
Lactato de sódio & 0,80 & 80 \\
Antioxidante & 0,25 & 25 \\
Total & 100,00 & 10.000 \\
\hline
\end{tabular}

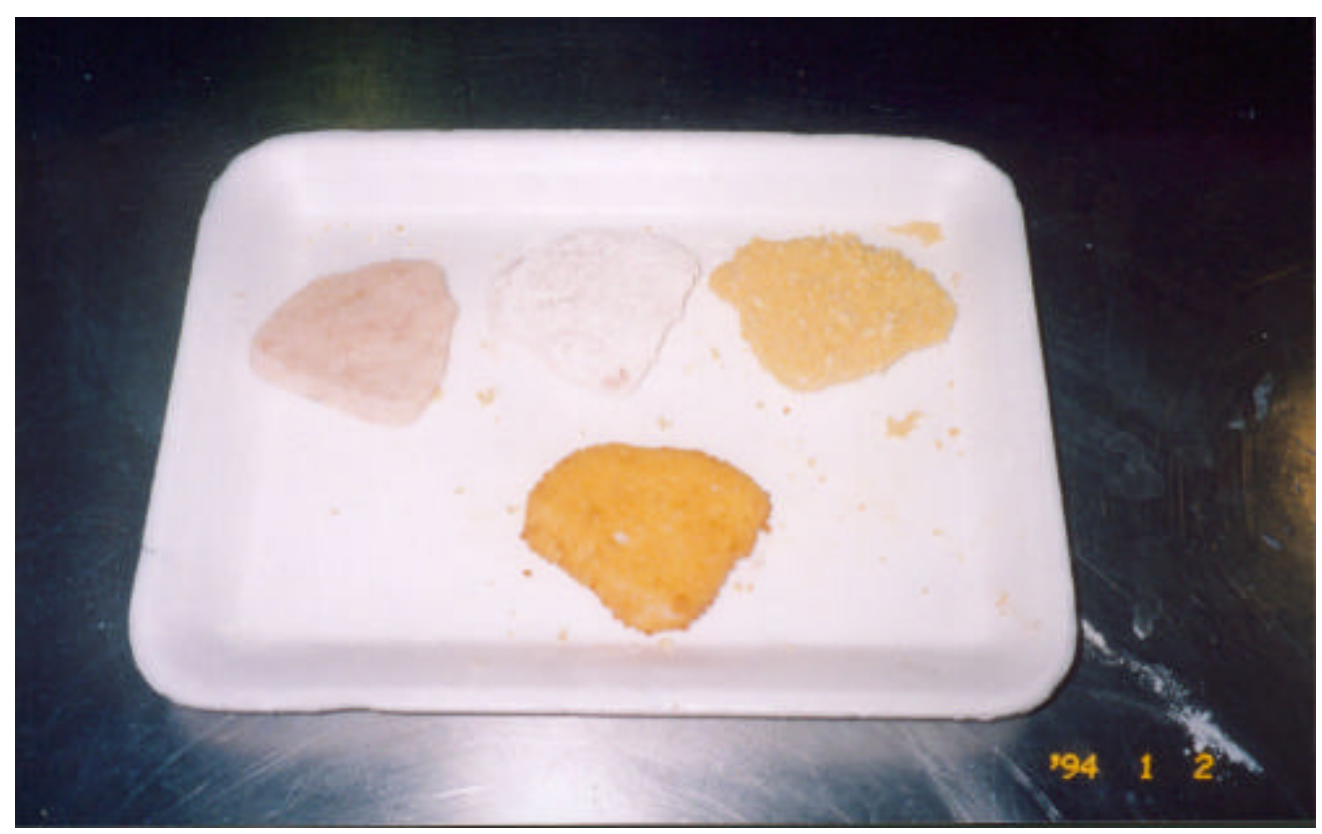

Figura 10 - Produto empanado reestruturado tipo nuggets. 


\subsubsection{Critério de avaliação dos consumidores}

Os consumidores foram entrevistados baseados no Critério de Classificação Econômica Brasil de acordo com a Associação Nacional de Empresas de Pesquisa ANEP (ANEP, 2001). Essa análise teve como objetivo estimar o poder de compra das pessoas e das famílias urbanas, abandonando deste modo, a pretensão de classificar a população em termos de classes sociais.

O sistema adotado baseourse na soma de pontos, onde a posse de cada item presente na primeira parte da ficha (Anexo) implicou na aquisição de pontos que, somados ao grau de instrução do chefe da família, indicou a que classe econômica pertencia o entrevistado.

De acordo com o LSE de 1996, o Brasil se divide em sete classes econômicas cada qual com sua faixa de pontos correspondentes, como pode ser observado na Tabela 3.

Tabela 3. Cortes do critério de classificação econômica.

\begin{tabular}{lc}
\hline Classe & Pontos \\
\hline A1 & $30-34$ \\
A2 & $25-29$ \\
B1 & $21-24$ \\
B2 & $17-20$ \\
C & $11-16$ \\
D & $6-10$ \\
E & $0-5$ \\
\hline
\end{tabular}

\subsubsection{Análise sensorial dos nuggets}

Foram aplicados, o teste de aceitação do consumidor e o teste de intenção de compra de localização central. Estes testes foram aplicados em três locais diferentes, sendo dois hipermercados e um supermercado, localizados na cidade de Campinas. Um total de 400 consumidores foi entrevistado. A ficha apresentada aos provadores (Anexo) continha um questionário inicial para classificação econômica dos mesmos. 
Com relação aos produtos, solicitoutse a avaliação global da aceitação de cada produto (aroma, sabor, suculência e textura) e também o teste de intenção de compra. A escala sensorial do teste de aceitação variou de 1 a 7 , sendo 1 referente ao "desgostei muitíssimo" e 7 referente ao "gostei muitíssimo". No teste de intenção de compra utilizourse uma escala variando de 1 (certamente não compraria) a 5 (certamente compraria).

Os nuggets congelados foram fritos por dois minutos em fritadeira elétrica a $180^{\circ} \mathrm{C}$. Imediatamente após a fritura os três tipos de nuggets (matriz, poedeira e frango) foram dispostos em uma bandeja de poliestireno expandido branca para serem servidos aos consumidores. Cada tipo de nugget foi codificado com algarismos de três dígitos aleatórios, diferentes para cada provador. Para a apresentação das amostras nas bandejas utilizourse o delineamento experimental de blocos completos balanceados.

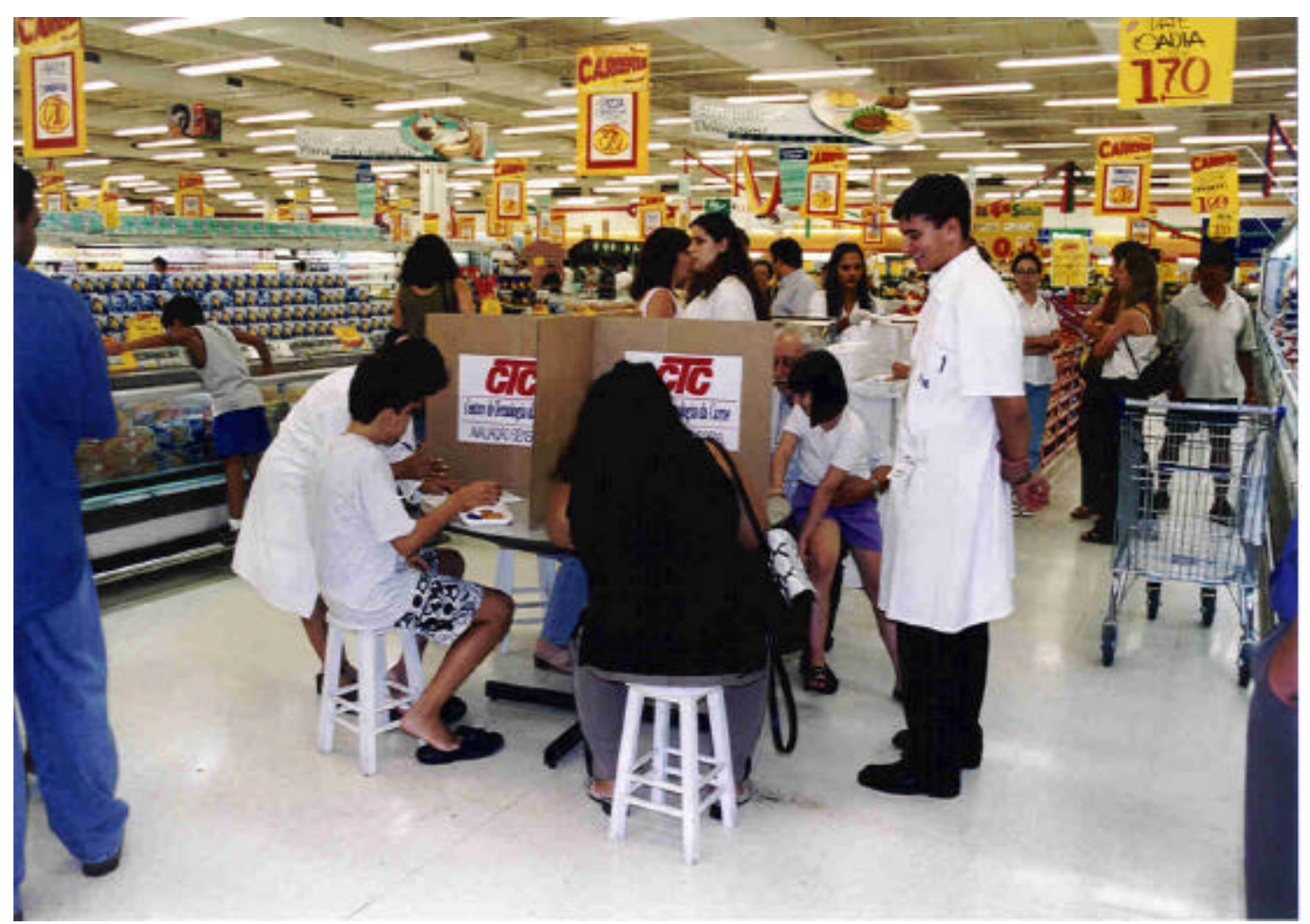

Figura 11 - Análise sensorial dos nuggets. 


\subsubsection{Análise estatística}

Para a análise e interpretação dos resultados do teste de aceitação procedeurse a análise de variância e Teste de Dunnet, utilizando o programa SAS, com o objetivo de verificar se houve ou não diferença entre os produtos elaborados. 


\section{RESULTADOS E DISCUSSÃO}

As CMSs obtidas tanto de galinhas matrizes quanto de galinhas poedeiras foram avaliadas quanto ao rendimento de extração, temperatura, $\mathrm{pH}$, caracterização e estabilidade microbiológica.

Os resultados dos rendimentos indicaram que as CMSs dos dois tipos de galinhas obtiveram resultados semelhantes. Observou-se que para galinhas poedeiras os rendimentos foram 68,0\%; 68,9\% e 67,5\% para a primeira, segunda e terceira extração respectivamente. Enquanto que para as CMSs de galinhas matrizes os rendimentos foram de 70\%; 70,6\% e 68,3\%. A média dos rendimentos obtidos $(68,1 \%$ e 69,6\% para galinhas poedeiras e matrizes respectivamente) corrobora com os valores citados por Froning \& McKee (2001), os quais afirmaram que o rendimento de CMS de aves varia de 55 a 70\% dependendo da pressão aplicada sobre a matéria-prima.

As temperaturas durante o processo de desossa manual e mecânica poder ser observadas na Tabela 4. 
Tabela 4. Registro das temperaturas $\left({ }^{\circ} \mathrm{C}\right)$ durante o processo de obtenção das CMSs nas três replicações do experimento.

\begin{tabular}{|c|c|c|c|c|c|c|c|c|}
\hline & \multicolumn{4}{|c|}{ Desossa manual } & \multicolumn{4}{|c|}{ Desossa mecânica } \\
\hline & \multicolumn{2}{|c|}{ Galinha matriz } & \multicolumn{2}{|c|}{ Galinha poedeira } & \multicolumn{2}{|c|}{ Galinha matriz } & \multicolumn{2}{|c|}{ Galinha poedeira } \\
\hline & inicial & final & Inicial & final & inicial & final & inicial & final \\
\hline $1^{\circ}$ replicação & 5 & 8 & 7 & 11 & -5 & -1 & -4 & -1 \\
\hline $2^{\circ}$ replicação & 1 & 3 & 0 & 4 & -4 & $-1,2$ & -4 & $-0,5$ \\
\hline $3^{\circ}$ replicação & -1 & 2 & -1 & 3 & -5 & $-1,5$ & -5 & -1 \\
\hline MÉDIA & 1,7 & 4,3 & 2 & 6 & $-4,7$ & $-1,2$ & $-4,3$ & $-0,8$ \\
\hline
\end{tabular}

Segundo os resultados indicados na Tabela 4, a maior temperatura registrada durante a desossa manual, tanto para galinhas matrizes quanto para galinhas poedeiras, ocorreu na primeira replicação do experimento. Tal fato se deveu em função da temperatura na sala de desossa, embora isso não tenha afetado a qualidade microbiológica da matéria-prima Porém observa-se que a temperatura final, após a desossa mecânica, foi semelhante para os dois tipos de CMS analisados durante as três replicações.

\subsection{Valor de pH}

Os valores de $\mathrm{pH}$ das amostras de CMSs obtidas neste trabalho estão apresentados na Tabela 5 e 6. 
Tabela 5. Valores médios do $\mathrm{pH}$ das CMSs de galinhas poedeiras controle e tratadas com nitrito e eritorbato ao longo da estocagem congelada a $-18^{\circ} \mathrm{C}$.

\begin{tabular}{lcccccccc}
\hline & \multicolumn{7}{c}{ Tempo (dias) } \\
\hline & 1 & 15 & 29 & 43 & 57 & 71 & 85 & 99 \\
PC & $6,6^{\mathrm{a}}$ & $6,4^{\mathrm{a}}$ & $6,7^{\mathrm{a}}$ & $6,6^{\mathrm{a}}$ & $6,6^{\mathrm{a}}$ & $6,6^{\mathrm{a}}$ & $6,5^{\mathrm{a}}$ & $6,6^{\mathrm{a}}$ \\
E.P. & 0,0 & 0,2 & 0,1 & 0,1 & 0,1 & 0,0 & 0,1 & 0,1 \\
PN & $6,7^{\mathrm{a}}$ & $6,5^{\mathrm{a}}$ & $6,7^{\mathrm{a}}$ & $6,6^{\mathrm{a}}$ & $6,6^{\mathrm{a}}$ & $6,6^{\mathrm{a}}$ & $6,6^{\mathrm{a}}$ & $6,6^{\mathrm{a}}$ \\
E.P. & 0,1 & 0,1 & 0,0 & 0,1 & 0,0 & 0,0 & 0,0 & 0,0 \\
PE & $6,7^{\mathrm{a}}$ & $6,4^{\mathrm{a}}$ & $6,7^{\mathrm{a}}$ & $6,6^{\mathrm{a}}$ & $6,6^{\mathrm{a}}$ & $6,6^{\mathrm{a}}$ & $6,6^{\mathrm{a}}$ & $6,6^{\mathrm{a}}$ \\
E.P. & 0,1 & 0,2 & 0,1 & 0,1 & 0,0 & 0,0 & 0,0 & 0,0 \\
\hline
\end{tabular}

Nota: $\mathrm{PC}$ - poedeira controle; $\mathrm{PN}$ - poedeira nitrito; $\mathrm{PE}$ - poedeira eritorbato E.P.= erro padrão

Médias com letras iguais na mesma linha não apresentam diferença significativa, em nível de $95 \%$ de significância.

Tabela 6. Valores médios do $\mathrm{pH}$ das CMSs de galinhas matrizes controle e tratadas com nitrito e eritorbato ao longo da estocagem congelada $\mathrm{a}-18^{\circ} \mathrm{C}$.

\begin{tabular}{lcccccccc}
\hline \multicolumn{7}{c}{ Tempo (dias) } \\
\hline MC & 1 & 15 & 29 & 43 & 57 & 71 & 85 & 99 \\
EP & $6,4^{\mathrm{a}}$ & $6,3^{\mathrm{a}}$ & $6,5^{\mathrm{a}}$ & $6,4^{\mathrm{a}}$ & $6,4^{\mathrm{a}}$ & $6,3^{\mathrm{a}}$ & $6,3^{\mathrm{a}}$ & $6,4^{\mathrm{a}}$ \\
MN & 0,2 & 0,4 & 0,1 & 0,0 & 0,0 & 0,1 & 0,1 & 0,0 \\
EP & $6,5^{\mathrm{a}}$ & $6,1^{\mathrm{a}}$ & $6,5^{\mathrm{a}}$ & $6,5^{\mathrm{a}}$ & $6,4^{\mathrm{a}}$ & $6,4^{\mathrm{a}}$ & $6,3^{\mathrm{a}}$ & $6,4^{\mathrm{a}}$ \\
ME & 0,1 & 0,2 & 0,1 & 0,0 & 0,0 & 0,0 & 0,2 & 0,1 \\
EP & $6,5^{\mathrm{a}}$ & $6,3^{\mathrm{a}}$ & $6,5^{\mathrm{a}}$ & $6,4^{\mathrm{a}}$ & $6,4^{\mathrm{a}}$ & $6,4^{\mathrm{a}}$ & $6,4^{\mathrm{a}}$ & $6,4^{\mathrm{a}}$ \\
\hline
\end{tabular}

Nota: $\mathrm{MC}$ - poedeira controle; $\mathrm{MN}$ - poedeira nitrito; $\mathrm{ME}$ - poedeira eritorbato E.P.= erro padrão

Médias com letras iguais na mesma linha não apresentam diferença significativa, em nível de $95 \%$ de significância. 
Observa-se que a CMS de galinhas poedeiras (Tabela 5) apresentou valor médio de $\mathrm{pH}$ levemente superior ao valor médio do $\mathrm{pH}$ da $\mathrm{CMS}$ de galinhas matrizes (Tabela 6). Mais uma vez, a explicação para os diferentes valores encontrados pode estar na menor proporção carne:osso das galinhas poedeiras e conseqüente maior incorporação de medula óssea, que apresenta elevado pH. Grunden et al. (1972) encontraram valores de $\mathrm{pH}$ de 6,2 e 6,6 para CMSs de galinhas poedeiras e de dorso+pescoço de frango, respectivamente. Kondaiah \& Panda (1987) mediram o pH de carne de peito e de coxa de galinhas desossadas manualmente, e encontraram valores de 5,94 e 6,08; respectivamente. Os filés de peito das galinhas matrizes e poedeiras, que foram retirados antes da separação mecânica neste trabalho, apresentaram pH de 5,7 e 5,8; respectivamente. Mesmo sabendo que a carne da coxa deve apresentar um $\mathrm{pH}$ pouco superior ao da carne do peito, fica claro por estes valores que a separação mecânica eleva o $\mathrm{pH}$ dos produtos.

Através da Tabela 4, observa-se que não houve variação significativa nos valores de $\mathrm{pH}$ ao longo dos 99 dias de estocagem. Tais dados estão de acordo os encontrados por Xavier \& Beraquet (1994), para CMS de frango pré-curada com nitrito e estocada por 10 dias sob refrigeração, cujo valor de $\mathrm{pH}$ variou entre 6,65 e 6,75.

Pelos dados obtidos, ainda foi possível observar que não ocorreram mudanças significativas no $\mathrm{pH}$ em função da adição dos aditivos, tanto nitrito como nitrito associado ao eritorbato. De acordo com Pollonio (1994), também não ocorreram variações do pH em CMS de frango com a adição de nitrito nem de ascorbato.

\subsection{Caracterização microbiológica das CMSs}

As análises de caracterização microbiológica das amostras de CMS foram conduzidas 12 horas após a extração, sendo os resultados médios apresentados na Tabela 7. 
Tabela 7. Valores médios da caracterização microbiológica das CMSs de galinhas matrizes e de galinhas poedeiras.

\begin{tabular}{lcc}
\hline & Galinhas Matrizes & Galinhas Poedeiras \\
\hline Mesófilos $(\log 10 \mathrm{UFC} / \mathrm{g})$ & 4,6 & 4,7 \\
Psicrotróficos $(\log 10 \mathrm{UFC} / \mathrm{g})$ & 5,0 & 5,1 \\
Pseudomonas $(\log 10 \mathrm{UFC} / \mathrm{g})$ & 3,9 & 3,5 \\
Staphylococcus aureus $(\log 10 \mathrm{UFC} / \mathrm{g})$ & 1,1 & 1,0 \\
Clostridium perfringens $(\log 10 \mathrm{UFC} / \mathrm{g})$ & $<1$ & 1,0 \\
E. coli $(\log 10 \mathrm{UFC} / \mathrm{g})$ & 2,0 & 2,2 \\
Salmonella spp. em $25 \mathrm{~g}$ & ausente & Ausente \\
\hline
\end{tabular}

De acordo com os valores médios apresentados, observou-se que a microbiota pré-existente tanto nas CMSs de galinhas poedeiras quanto de galinhas matrizes foram bem semelhantes entre si, não se detectando a presença de Salmonella spp. (ausência em $25 \mathrm{~g}$ ) em nenhum dos dois tipos de CMS.

As análises de microrganismos psicrotróficos mostraram contagens inferiores ao encontrado por Kumar et al. (1986) que estudando CMS de galinhas de descarte nas mesmas condições operacionais deste trabalho obtiveram a contagem total de psicrotróficos de 7,3 $\log 10 \mathrm{UFC} / \mathrm{g}$, tal diferença nos valores indica a boa qualidade da matéria-prima e das condições de extração realizadas no presente experimento. Outros trabalhos do acervo bibliográfico, tais como Xavier \& Beraquet (1994) encontram uma contagem de 4,5 $\log 10 \mathrm{UFC} / \mathrm{g}$ em CMS de dorso de frango, bem como Ostovar et al. (1971) que reportaram uma contagem de 5,5 log10 UFC/g com CMS provenientes também de dorso.

Quanto à análise de E. coli, as contagens encontradas foram inferiores ao valor de 4,3 $\log 10 \mathrm{UFC} / \mathrm{g}$ encontrado por Kumar et al. (1986), porém semelhante à reportada por Ostovar et al. (1971), (2,7 log10 UFC/g) em CMS de galinha de descarte. A presença de coliformes indica direta ou indiretamente contaminação por matéria fecal, por essa razão medidas sanitárias adequadas foram adotadas garantindo a segurança da CMS que foi utilizada no trabalho de pesquisa. 
A resolução RDC nº 12, da Agência Nacional de Vigilância Sanitária (ANVISA), de 12 de janeiro de 2001 estabelece para carnes resfriadas, ou congeladas "in natura" de aves (carcaças inteiras, fracionadas ou cortes) como único indicativo microbiológico o número de coliformes fecais, sendo este estipulado em $10^{4} \mathrm{NMP} / \mathrm{g}$ (Anvisa, 2002). Como a média dos valores obtidos no presente trabalho ficou próximo de $10^{2} \mathrm{NMP} / \mathrm{g}$, pode-se dizer que as CMSs obtidas atendem perfeitamente os padrões microbiológicos da legislação Brasileira.

No caso da determinação de Staphylococcus. aureus verificou-se a presença destes microrganismos nos dois tipos de CMS analisadas, sendo as contagens semelhante a encontrada por Kumar et al. (1986) (<2,0 $\log 10$ UFC/g). Porém, Bijker et al. (1987) monitorando a qualidade microbiológica de carnes mecanicamente separadas de carcaças de frango inteiras, analisadas imediatamente após a extração, encontraram uma contagem de 3,6 log10 UFC/g, bem superior às contagens obtidas nesse trabalho.

Em relação à análise de Clostridium perfringens foram detectadas contagens relativamente baixas e apenas presentes na CMS de galinha poedeira (Tabela 7). Como os dois tipos de galinhas sofreram o mesmo processamento e obtiveram contagens semelhantes em todas as outras análises pode-se afirmar que esse microrganismo estava presente na microbiota inicial das aves e que sua presença não se deve a uma contaminação durante o processo. A contagem encontrada no presente trabalho foi inferior a encontrada por Kumar et al. (1986) (4,11 $\log 10 \mathrm{UFC} / \mathrm{g})$ indicando a boa qualidade da matéria-prima e das condições do processamento durante a extração.

A contagem microbiológica dos microrganismos analisados, obtida nesse trabalho, está de acordo com a Instrução Normativa no 4 de 31 de março de 2000 da Secretaria de Defesa Agropecuária do Ministério da Agricultura e Abastecimento, a qual exige ausência de Salmonella spp. em $25 \mathrm{~g}$, e permite contagem máxima de 5x10 $\mathrm{UFC} / \mathrm{g}$ para $S$. aureus e $1 \times 10^{3} \mathrm{UFC/g}$ para $C$. perfringens em carne mecanicamente separada de aves, bovinos e suínos. 


\subsection{Contagem dos microrganismos nas CMSs tratadas e congeladas no $1^{\circ}$ e no $99^{\circ}$} dia

Após a obtenção das CMSs, as amostras controle, as tratadas com nitrito e nitrito mais eritorbato foram congeladas a $-18^{\circ} \mathrm{C}$ por 99 dias de modo a avaliar a estabilidade microbiológica.

As Tabelas 8 e 9 resumem as análises de variâncias das contagens de todos os microrganismos analisados, exceto para psicrotróficos aeróbios, nas CMS de galinhas poedeiras e matrizes respectivamente.

Tabela 8. Resumo da análise de variância das análises microbiológicas em CMS de galinhas poedeiras, considerando o valor $\mathrm{F}$ e os níveis de significância.

\begin{tabular}{lccc}
\hline & \multicolumn{3}{c}{ Fatores } \\
\hline Variáveis & Tempo & Tratamento & Interação \\
\hline Pseudomonas & $7,43^{*}$ & $1,65^{\mathrm{NS}}$ & $0,21^{\mathrm{NS}}$ \\
Mesófilos & $7,58^{*}$ & $0,1^{\mathrm{NS}}$ & $0,18^{\mathrm{NS}}$ \\
C. perfringens & $1,60^{\mathrm{NS}}$ & $0,70^{\mathrm{NS}}$ & $0,70^{\mathrm{NS}}$ \\
S. aureus & $3,00^{\mathrm{NS}}$ & $0,0004^{\mathrm{NS}}$ & $0,0004^{\mathrm{NS}}$ \\
E. coli & $5,26^{*}$ & $0,16^{\mathrm{NS}}$ & $0,75^{\mathrm{NS}}$ \\
\hline
\end{tabular}

Nota: Tratamento: controle, $150 \mathrm{ppm}$ de nitrito, $150 \mathrm{ppm}$ de nitrito $+500 \mathrm{ppm}$ de eritorbato $*=\mathrm{p}<0,05$

NS: não significativo 
Tabela 9. Resumo da análise de variância das análises microbiológicas em CMS de galinhas matrizes, considerando o valor F e os níveis de significância.

\begin{tabular}{lclc}
\hline \multirow{2}{*}{ Variáveis } & \multicolumn{3}{c}{ Fatores } \\
\cline { 2 - 4 } & \multicolumn{1}{c}{ Tempo } & Tratamento & Interação \\
\hline Pseudomonas & $0,22^{\mathrm{NS}}$ & $0,65^{\mathrm{NS}}$ & $0,02^{\mathrm{NS}}$ \\
Mesófilos & $7,49^{*}$ & $0,76^{\mathrm{NS}}$ & $0,19^{\mathrm{NS}}$ \\
C. perfringens & $4,32^{\mathrm{NS}}$ & $0,48^{\mathrm{NS}}$ & $0,48^{\mathrm{NS}}$ \\
S. aureus & $1,09^{\mathrm{NS}}$ & $0,15^{\mathrm{NS}}$ & $0,96^{\mathrm{NS}}$ \\
E. coli & $0,96^{\mathrm{NS}}$ & $0,93^{\mathrm{NS}}$ & $0,14^{\mathrm{NS}}$ \\
\hline
\end{tabular}

Nota: Tratamento: controle, $150 \mathrm{ppm}$ de nitrito, $150 \mathrm{ppm}$ de nitrito $+500 \mathrm{ppm}$ de eritorbato $*=\mathrm{p}<0,05$

NS: não significativo

Observa-se nas Tabelas 8 e 9 que embora não tenha havido diferença significativa entre os tratamentos $(p>0,05)$, observou-se que o efeito do fator tempo de estocagem foi significativo $(\mathrm{p}<0,05)$ para as análises de Pseudomonas, mesófilos e E. coli nas CMSs de galinhas poedeiras e somente significativa para a análise de mesófilos nas CMSs de galinhas matrizes. Tais resultados indicam que o congelamento foi o fator primordial na redução da microbiota presente nas CMSs, independentemente do tratamento utilizado. Observa-se que o efeito do congelamento foi mais eficiente na diminuição da contagem de alguns microrganismos para as CMSs de galinhas poedeiras que para as CMSs de galinhas matrizes. Isso provavelmente se deveu a natureza dos microrganismos e a localização dos mesmos na massa cárnea, pois todos os outros fatores que poderiam influenciar a taxa de sobrevivência, como a composição do alimento, a temperatura do congelamento, o tempo do armazenamento e o processamento foram controlados e semelhantes para os dois tipos de galinhas. 
As Figuras 12 e 13 mostram as mudanças na contagem de mesófilos aeróbios, Pseudomonas e E. coli em CMS de galinhas poedeiras e matrizes, respectivamente, tratadas com nitrito e nitrito mais eritorbato durante a estocagem congelada a $-18^{\circ} \mathrm{C}$ por 99 dias.

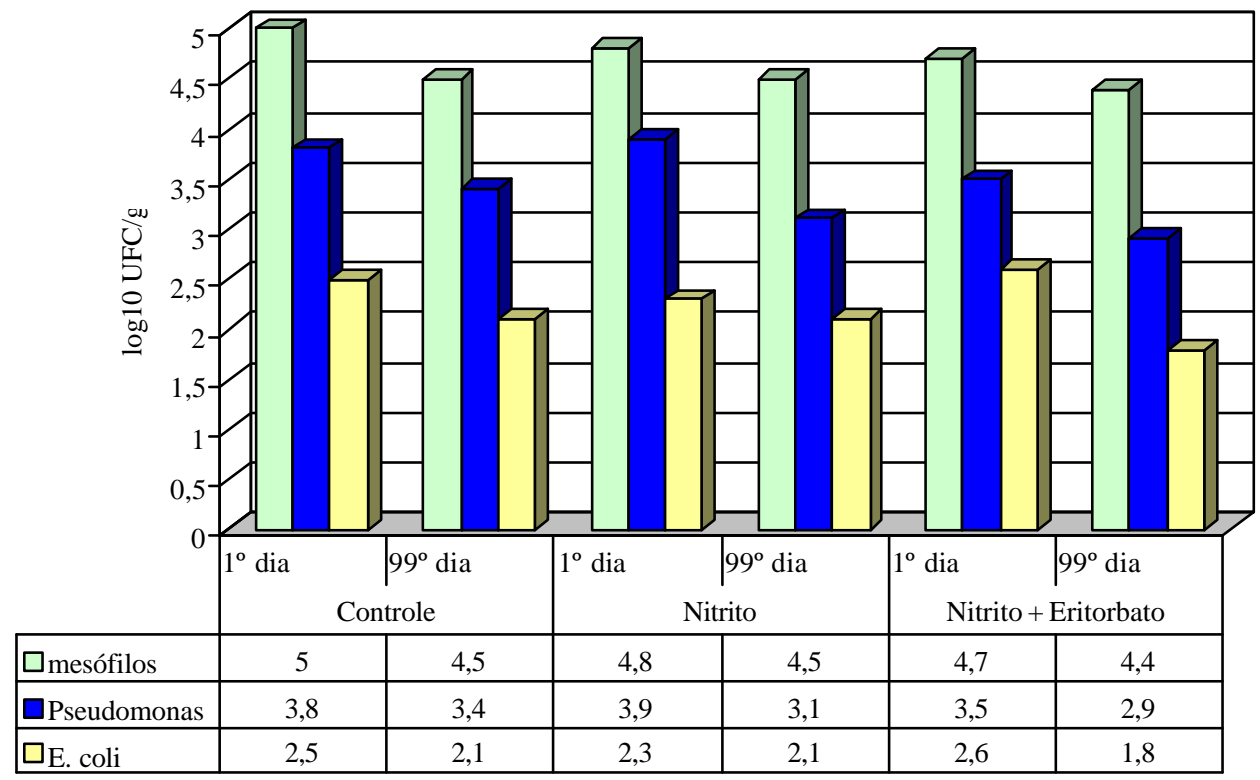

Figura 12 - Variação na contagem média de mesófilos aeróbios, Pseudomonas e E. coli durante a estocagem congelada a $-18^{\circ} \mathrm{C}$ em CMS de galinhas poedeiras tratadas com nitrito (150ppm) e nitrito mais eritorbato $(150 \mathrm{ppm}+500 \mathrm{ppm})$. 


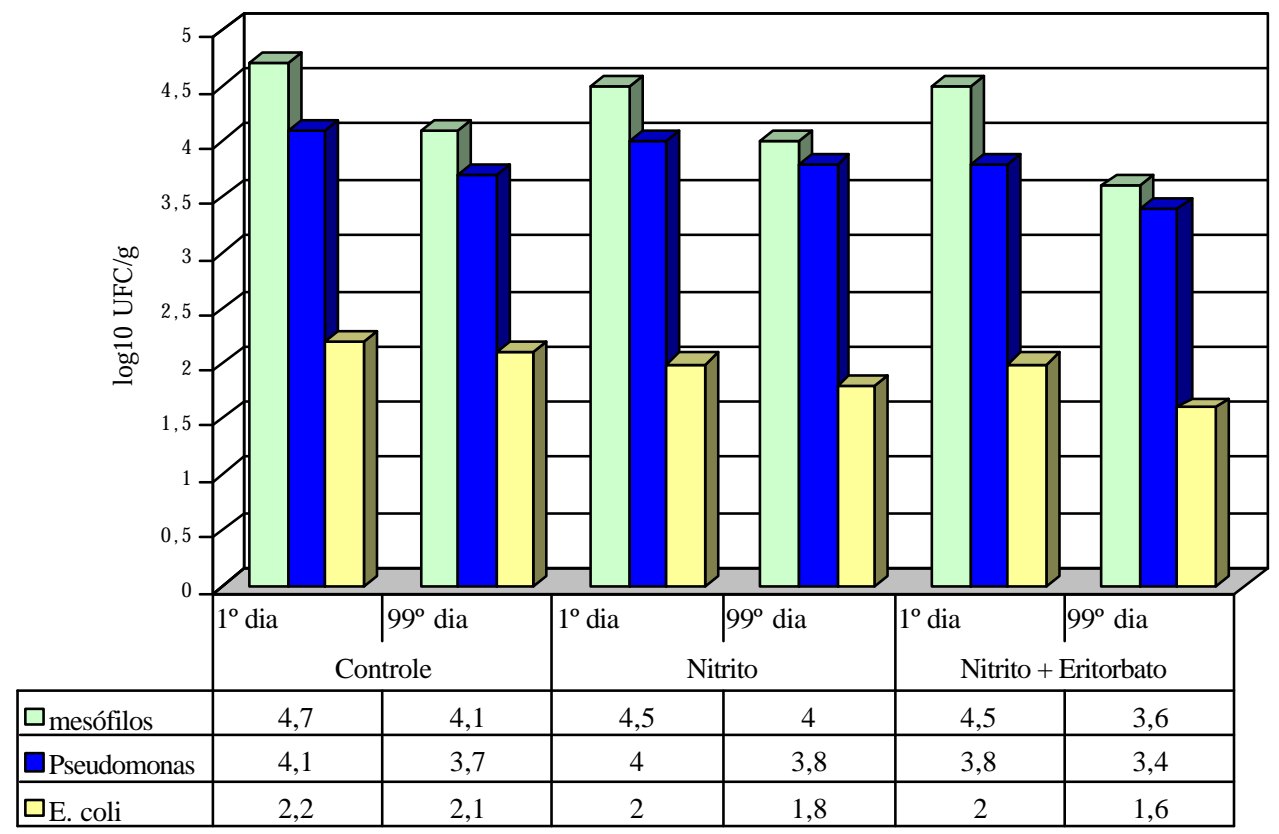

Figura 13 - Variação na contagem média de mesófilos aeróbios, Pseudomonas e E. coli durante a estocagem congelada a $-18^{\circ} \mathrm{C}$ em CMS de galinhas matrizes tratadas com nitrito $(150 \mathrm{ppm})$ e nitrito mais eritorbato $(150 \mathrm{ppm}+500 \mathrm{ppm})$.

De acordo com os resultados mostrados nas Figuras 11 e 12, observa-se que o congelamento reduziu a carga microbiana tanto para o controle quanto para os tratamentos (nitrito e nitrito mais eritorbato) durante o período avaliado nas CMSs de galinhas poedeiras e nas CMSs de galinha matriz, corroborando, deste modo, com os dados encontrados por Kumar et al. (1986) e Ostovar et al. (1971).

No início do período avaliado, ou seja, após 24 horas do início do processo de cura, com as amostras apenas refrigeradas, também não foram observadas reduções microbiológicas significativas entre os tratamentos.

Tal resultado corrobora com Takano et al. (1979), os quais afirmaram que o processo de congelamento faz pouco para reduzir a flora microbiana, além de existir a possibilidade de bactérias patogênicas ou deteriorantes sobreviverem durante a estocagem congelada causando toxinfecções de origem alimentar ou a deterioração do alimento após o descongelamento. 
A redução não significativa da contagem microbiológica também pode ser justificada em função dos valores de pH mostrados através das Tabelas 5 e 6. A adição tanto do nitrito quanto do eritorbato não levaram a uma redução significativa do $\mathrm{pH}$ no final do período avaliado, mantendo deste modo, um meio propício para o desenvolvimento bacteriano. Concomitante a esse fator também pode se afirmar que o nitrito, em valores de $\mathrm{pH}$ como os encontrados nesse trabalho, não é convertido em ácido nitroso o qual é a forma com maior poder bactericida.

A ausência da atividade do nitrito, em relação à diminuição não significativa da carga bacteriológica nas CMSs analisadas, pode ser discutida de acordo com Bushway et al. (1982). Tais pesquisadores verificando o efeito do nitrito no número de microrganismos aeróbios em hambúrgueres de carne clara e escura de frango obtiveram resultados controversos. Enquanto níveis de 100 a 150 ppm de nitrito reduziram cerca de 2 ciclos logarítmicos da contagem total nos produtos utilizando carne clara, não obtiveram os mesmos resultados quando utilizaram a carne escura.

A carga microbiológica presente nas CMSs controle, tanto de galinhas poedeiras, quanto de galinhas matrizes foi inferior quando comparada com os valores presente na literatura. Kumar et al. (1986) encontraram para CMS de galinhas contagem de 4,3 $\log 10 \mathrm{UFC} / \mathrm{g}$ para coliformes fecais; 4,11 $\log 10 \mathrm{UFC} / \mathrm{g}$ para Clostridium e 7,30 $\log 10$ UFC/g para psicrotróficos aeróbios, enquanto esse trabalho encontrou a contagem máxima de 2,5 $\log 10 \mathrm{UFC} / \mathrm{g} ; 3,0 \log 10 \mathrm{UFC} / \mathrm{g}$ e 5,6 $\log 10 \mathrm{UFC} / \mathrm{g}$ para coliformes fecais, Clostridium e psicrotróficos aeróbios, respectivamente. Tal diferença pode estar relacionada com as baixas temperaturas obtidas durante e após o processo de separação mecânica (Tabela 4). Verifica-se que esse é um ponto de extrema importância para a manutenção da qualidade final da CMS.

Nas Tabelas 10 e 11 pode-se observar as contagens de Staphylococcus aureus e Clostridium perfringens, respectivamente nas CMSs analisadas nas três replicações do experimento. 
Tabela 10. Contagem de Staphylococcus aureus em CMSs de galinhas poedeiras e matrizes no $1^{\circ}$ e no $99^{\circ}$ dia de estocagem congelada a $-18^{\circ} \mathrm{C}(\log 10$ $\mathrm{UFC} / \mathrm{g})$.

\begin{tabular}{lcccccc}
\hline & \multicolumn{5}{c}{ Staphylococcus aureus } \\
\cline { 2 - 7 } & \multicolumn{2}{c}{$1^{\mathbf{0}}$ replicação } & $2^{\mathbf{0}}$ replicação & $3^{\circ}$ replicação \\
\hline Dia 1 & Dia 99 & Dia 1 & Dia 99 & Dia 1 & Dia 99 \\
\hline Poedeira controle & 2,8 & $<1$ & $<1$ & $<1$ & $<1$ & $<1$ \\
Poedeira nitrito & 2,8 & $<1$ & $<1$ & $<1$ & $<1$ & $<1$ \\
Poedeira nitrito + eritorbato & 2,9 & $<1$ & $<1$ & $<1$ & $<1$ & $<1$ \\
Matriz controle & 2,0 & $<1$ & $<1$ & $<1$ & $<1$ & $<1$ \\
Matriz nitrito & $<1$ & $<1$ & $<1$ & 1 & $<1$ & $<1$ \\
Matriz nitrito + eritorbato & 2,5 & $<1$ & $<1$ & $<1$ & $<1$ & $<1$ \\
\hline
\end{tabular}

Segundo a Tabela 10, a presença de Staphylococcus aureus no primeiro dia de análise foi detectada apenas na primeira replicação do experimento na maioria dos tratamentos, com exceção da CMS de galinha matriz tratada com nitrito. Essa diferença na contagem deve-se provavelmente a microbiota inicial das carcaças, pois as temperaturas das carcaças no final da desossa manual (Tabela 4) não foram suficientemente altas a ponto de favorecer o crescimento desse microrganismo. Por outro lado, foi detectada a presença de $S$. aureus no final do período de estocagem em apenas uma das replicações, indicando a sobrevivência desse microrganismo sob baixas temperaturas e sob o tratamento com nitrito.

Apesar da maior resistência ao congelamento e a estocagem congelada das bactérias gram-positivas, tal como o $S$. aureus, nota-se uma redução de aproximadamente dois ciclos logarítmicos na primeira replicação do experimento. As razões para tal resultado podem ser explicadas em função da velocidade do descongelamento, tal como foi observado por Olson et al. (1981), onde o congelamento lento associado ao descongelamento lento foi mais prejudicial às bactérias que o 
congelamento rápido seguido do descongelamento rápido. Ou ainda, pode ser explicada em função da não recuperação das células injuriadas pelo processo de congelamento.

Tabela 11. Contagem de Clostridium perfringens em CMS de galinhas poedeiras e matrizes no $1^{\circ}$ e no $99^{\circ}$ dia de estocagem congelada a $-18^{\circ} \mathrm{C}(\log 10$ $\mathrm{UFC} / \mathrm{g})$.

\begin{tabular}{lcccccc}
\hline & \multicolumn{5}{c}{ Clostridium perfringens } \\
\cline { 2 - 7 } & \multicolumn{2}{c}{$1^{\circ}$ replicação } & $2^{\circ}$ replicação & $3^{\circ}$ replicação \\
\hline & Dia 1 & Dia 99 & Dia 1 & Dia 99 & Dia 1 & Dia 99 \\
\hline Poedeira controle & $<1$ & $<1$ & $<1$ & $<1$ & 3,0 & $<1$ \\
Poedeira nitrito & $<1$ & $<1$ & 1,0 & $<1$ & $<1$ & $<1$ \\
Poedeira nitrito + eritorbato & $<1$ & $<1$ & $<1$ & $<1$ & $<1$ & $<1$ \\
Matriz controle & $<1$ & $<1$ & 2,6 & $<1$ & 1,3 & $<1$ \\
Matriz nitrito & $<1$ & $<1$ & $<1$ & $<1$ & 1,0 & $<1$ \\
Matriz nitrito + eritorbato & $<1$ & $<1$ & 2,7 & $<1$ & $<1$ & $<1$
\end{tabular}

Na Tabela 11, observa-se a contagem de Clostridium perfringens nas amostras de CMS de galinha matriz e de galinha poedeira. Como era esperado, não foi observada a sobrevivência de bactérias do gênero Clostridium no final do período analisado. Tais resultados corroboram com White \& Hall (1984a) que verificando o comportamento do $C$. perfringens durante a estocagem congelada, afirmaram que essa bactéria foi altamente sensível ao processo de congelamento contrariamente ao comportamento de outras bactérias causadoras de intoxicações. Aliado a esse fator o efeito inibitório do nitrito de sódio sobre as bactérias do gênero Clostridium foi reportado por diversos autores (Carpenter et al., 1987; McMindes \& Siedler, 1988; Riha Jr. \& Solberg, 1976; Tompkin et al., 1978; Woods \& Wood, 1982). Resumidamente, o nitrito inibe a bactéria reduzindo o teor de ATP intracelular e aumentando a concentração de piruvato. O 
aumento do piruvato age no sistema fosforoclástico, o qual é uma importante fonte de ATP nas bactérias do gênero Clostridium. O sistema fosforoclástico converte o piruvato a gás carbônico, hidrogênio e acetil fosfato, o qual é convertido a acetato pela acetatoquinase mais $\mathrm{ADP}$. O óxido nítrico formado via ácido nitroso através do nitrito reage com as proteínas ferro-enxofre das bactérias, ferredoxina e a piruvato ferredoxina oxidoredutase, inativando-as. Essas proteínas são importantes no metabolismo energético e deste modo são alvos da ação bacteriostática do nitrito.

Como as contagens mais elevadas foram encontradas na segunda e terceira replicação, pressupõe-se que esses microrganismos se encontravam presentes na microbiota inicial da ave.

Assim como em todas as outras análises anteriores, não foi detectada diferença significativa entre as amostras, indicando mais uma vez o efeito do congelamento na diminuição da contagem microbiana.

Não foi detectada a presença de Salmonella spp. (ausência em $25 \mathrm{~g}$ ) em nenhuma das amostras analisadas durante todo o período analisado.

A ausência do efeito do nitrito e do nitrito mais eritorbato encontrada nesse experimento corrobora com a afirmação de Bjirker et al. (1987), onde diz que a o ato de pré-curar as carcaças (matéria-prima para a obtenção da CMS) com nitrito em uma concentração de até 0,6\% não deve ser adotada, pois observa-se apenas um efeito bacteriostático superficial, sendo a deterioração de fato mascarada.

\subsection{Contagem dos microrganismos psicrotróficos ao longo dos 99 dias sob estocagem congelada}

As Tabelas 12 e 13 resumem a análise de variância das contagens de microrganismos psicrotróficos das CMS de galinhas poedeiras e matrizes respectivamente. 
Tabela 12. Resumo da análise de variância para as contagens de microrganismos psicrotróficos $(\log 10 \mathrm{UFC} / \mathrm{g})$ em CMS de galinhas poedeiras.

\begin{tabular}{lccc}
\hline Efeito & GL efeito & Valor F & Pr>F \\
\hline Tratamento & 7 & 8,48 & $<0,0001$ \\
Tempo & 2 & 5,27 & $<0,05$ \\
Inter (trat*tempo) & 14 & 0,41 & 0,9653 \\
\hline
\end{tabular}

Através dos dados apresentados na Tabela 12, observa-se que os resultados da CMS de galinhas poedeiras foram significativos em relação ao fator tempo de estocagem congelada $(\mathrm{p}<0,001)$ e ao fator tratamento $(\mathrm{p}<0,05)$ (nitrito e nitrito mais eritorbato), entretanto não foi observada diferença estatística na interação entre o fator tempo e o fator tratamento.

A Tabela 13 mostra que não houve diferença estatística nos resultados da CMS de galinhas matrizes para nenhum dos fatores analisados (tempo e tratamento) e nem para a interação entre os mesmos.

Tabela 13. Resumo da análise de variância para as contagens de microrganismos psicrotróficos $(\log 10 \mathrm{UFC} / \mathrm{g})$ em CMS de galinhas matrizes.

\begin{tabular}{lccc}
\hline Efeito & GL efeito & Valor F & Pr>F \\
\hline Tratamento & 7 & 0,6399 & 0,7207 \\
Tempo & 2 & 0,7603 & 0,4731 \\
Inter (trat*tempo) & 14 & 0,2575 & 1,0000 \\
\hline
\end{tabular}

É possível que uma parte dos microrganismos remanescentes estivessem injuriados pelo congelamento, bem como é possível que existisse uma porcentagem de mortes, provavelmente em função das condições negativas de estocagem, como a presença do nitrito.

Através das figuras 14 e 15 pode-se observar a contagem dos microrganismos psicrotróficos aeróbios ao longo de 99 dias sob estocagem congelada a $-18^{\circ} \mathrm{C}$, em CMS de galinhas poedeiras e matrizes respectivamente. As contagens iniciais nas 
CMSs controle obtidas no presente trabalho, tanto para a CMS de galinhas matrizes quanto para a CMS de galinhas poedeiras, foram inferiores ao valor reportado por Kumar et al. (1986) (7,3 $\log 10 \mathrm{UFC} / \mathrm{g})$. Porém foram próximos ao valor encontrado por Maxcy et al. (1973), os quais detectaram uma contagem microbiológica inicial de $5 \log 10 \mathrm{UFC} / \mathrm{g}$.

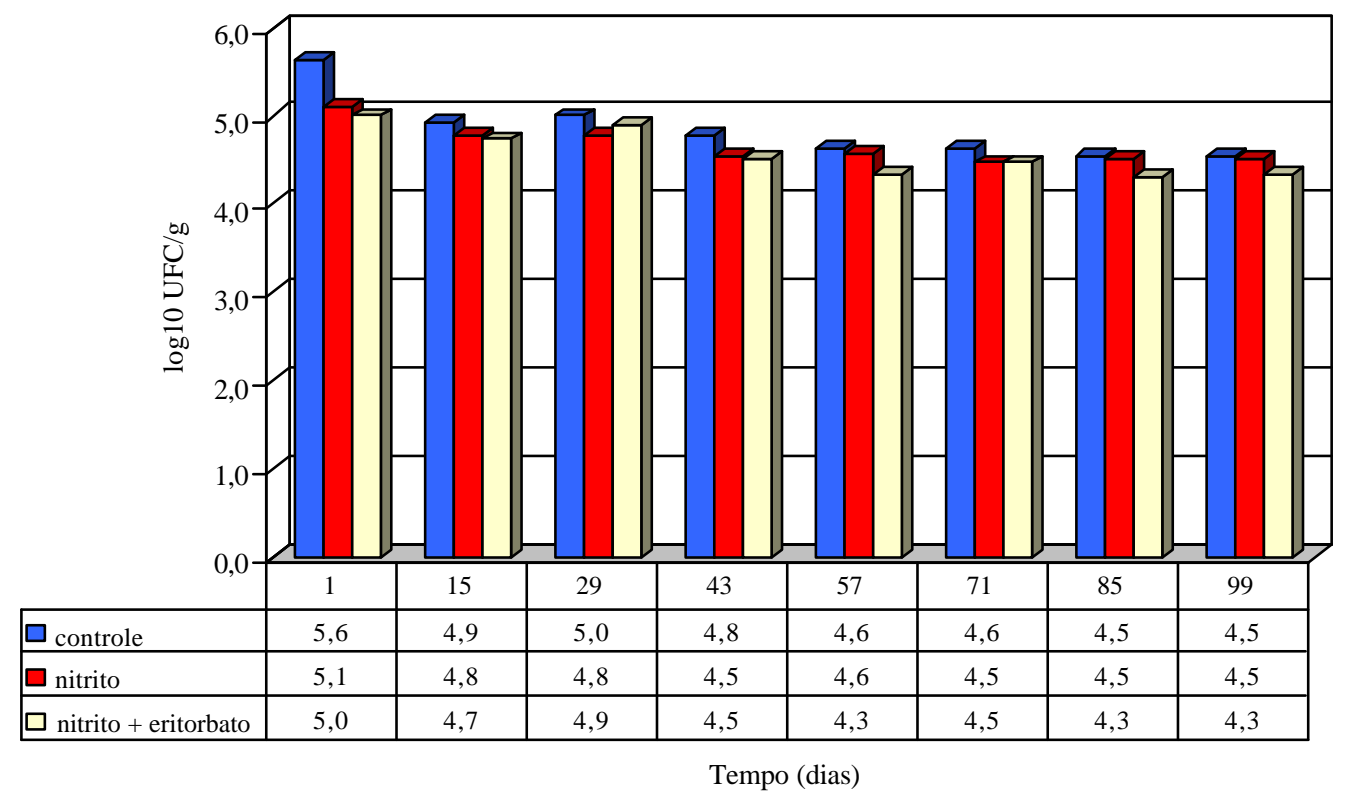

Figura 14 - Média da contagem total de microrganismos psicrotróficos durante a estocagem congelada em CMS de galinhas poedeiras tratadas com nitrito (150ppm) e nitrito mais eritorbato (150ppm $+500 \mathrm{ppm})$. 


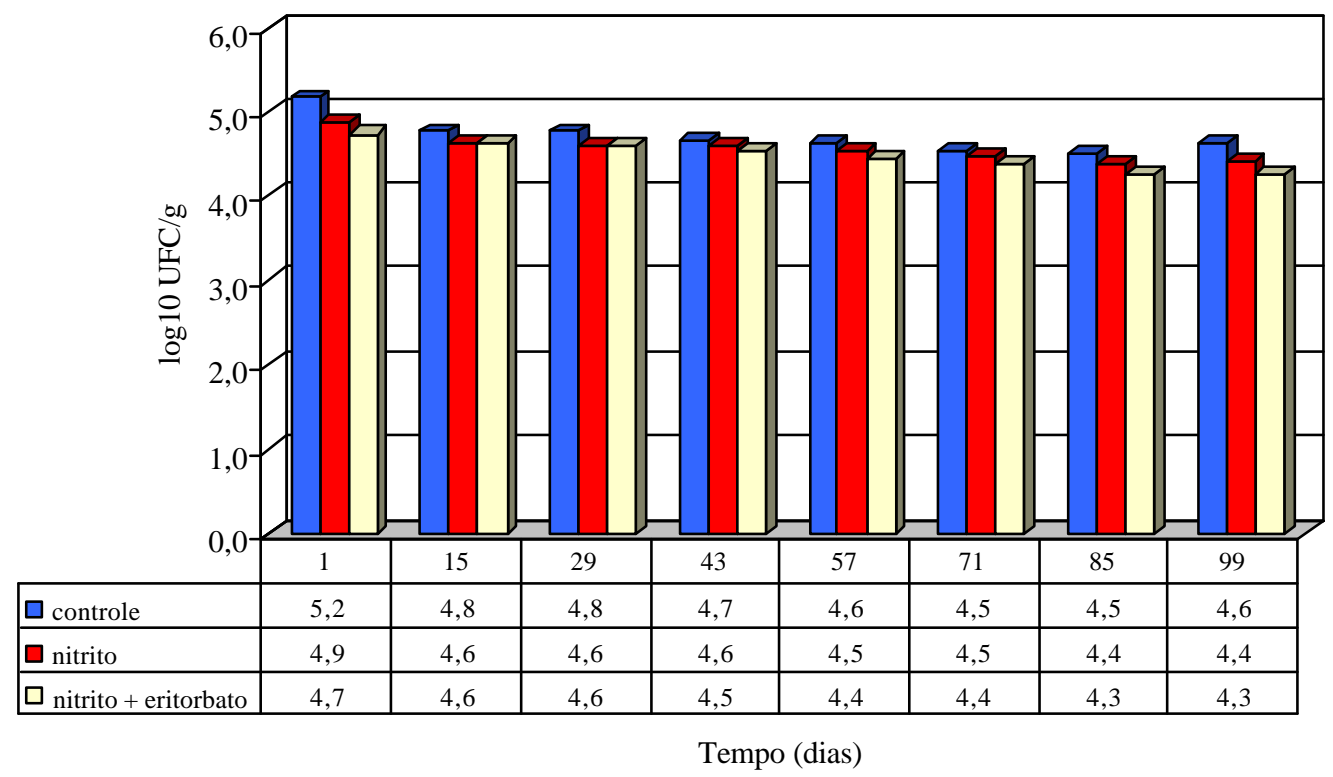

Figura 15 - Média da contagem total de microrganismos psicrotróficos durante a estocagem congelada em CMS de galinhas matrizes tratadas com nitrito (150ppm) e nitrito mais eritorbato (150ppm + 500ppm).

De acordo com os resultados mostrados nas Figuras 14 (CMS de galinha poedeira) e 15 (CMS de galinha matriz) é possível observar que independentemente do tratamento ou do tipo de galinha utilizada ocorreu uma diminuição na contagem microbiológica e que essa perda da viabilidade celular durante a estocagem congelada foi mais acentuada no início do congelamento e se tornou mais lenta em função do tempo até que o número de células fosse estável. Esse resultado corrobora com a afirmação de Christophersen (1968).

Avaliando a correlação entre o pH (Tabelas 5 e 6) com a contagem de psicrotróficos aeróbios (Figuras 12 e 13) durante a estocagem congelada por 99 dias, observa-se que houve uma correlação extremamente baixa entre essas duas variáveis, sendo o maior $\mathrm{r}^{2}$ de 0,5 para as CMSs de galinhas matrizes tratada com nitrito e o menor $\mathrm{r}^{2}$ de 0,0 para as CMSs de galinhas matrizes tratada com eritorbato. Os demais valores foram $r^{2}$ de 0,3 para as CMSs de galinhas poedeiras controle e as tratadas com eritorbato e $r^{2}$ de 0,2 para as CMSs de galinhas matrizes controle e de galinhas poedeiras tratadas 
com eritorbato. Deste modo pode-se concluir que o $\mathrm{pH}$ não pode ser considerado um bom indicativo do grau de contaminação microbiológica corroborando com Xavier \& Beraquet (1994).

Através da comparação das Figuras 14 e 15, referente a contagem de psicrotróficos aeróbios, com as Figuras 12 e 13, para a análise de Pseudomonas, observa-se que as bactérias do gênero Pseudomonas constituíram a grande maioria dos microrganismos psicrotróficos aeróbios nas CMS analisadas tanto de galinhas poedeiras quanto de galinhas matrizes controle e as tratadas com nitrito e nitrito mais eritorbato. Tais resultados corroboram com a afirmação de Gill \& Newton (1978), os quais reportaram que a microbiota deteriorante em carnes armazenadas com presença de oxigênio são na maioria, invariavelmente, dominada por espécies de Pseudomonas. Esses organismos estritamente aeróbios, gram-negativos, produzem compostos de odor desagradável quando metabolizam os aminoácidos, e são a principal causa do odor e do sabor não característico desenvolvido em carnes frescas.

A justificativa para o baixo efeito bactericida do nitrito pode ter dois principais fatores contribuintes. O primeiro é que pelo fato da $\mathrm{CMS}$ possuir um $\mathrm{pH}$ naturalmente mais elevado $(6,4-6,7)$ implicaria na não conversão do nitrito em ácido nitroso que é a forma de maior poder bactericida. O segundo fator seria as altas concentrações de ferro presentes na CMS. Tompkin et al. (1979) demonstraram a relação entre o aumento do teor de ferro e a diminuição da atividade antibotulínica do nitrito. Estes pesquisadores sugeriram que o ferro reage com o óxido nítrico produzido através do nitrito e deste modo reduz a concentração de óxido nítrico, que por sua vez deveria reagir com o composto de ferro contido no interior da célula vegetativa. Segundo Bushway et al (1982) é altamente possível que reações similares ocorram para a inibição de bactérias aeróbias através do nitrito.

A diminuição pouco acentuada observada nas contagens dos microrganismos psicrotróficos durante a estocagem congelada pode ser justificada em função da inexistência do processo de desnaturação das proteínas celulares e subseqüente processo de floculação que é mais intenso em temperaturas de armazenamento superiores a $-10^{\circ} \mathrm{C}$ (Delazari, 1980). Deste modo a sobrevivência de patógenos em carnes congeladas é 
maior em temperaturas de estocagem mais baixas, como a usada nesse experimento, onde a temperatura foi de $-18^{\circ} \mathrm{C}$.

A redução pouco significativa, também pode ser justificada segundo Sulzbacher (1950), o qual verificou que durante o congelamento de carnes embaladas a $-4^{\circ} \mathrm{C}$ e até a $-18^{\circ} \mathrm{C}$, o número de bactérias psicrotróficas até aumentava. Esse aumento foi atribuído ao crescimento microbiológico durante o congelamento lento da carne (tal como o realizado nesse experimento). Sob essas condições o crescimento poderia exceder o subseqüiente efeito letal do congelamento.

\subsection{Caracterização dos filés de peito}

Os filés de peito que foram utilizados para o preparo dos nuggets foram caracterizados quanto à composição centesimal, $\mathrm{pH}$, capacidade de retenção de água (CRA) e capacidade de emulsificação (CE).

\subsubsection{Composição centesimal}

Os teores de proteína, gordura, umidade e cinzas encontrados neste trabalho (Tabela 14) foram muito próximos para os três tipos de filés de peito (frango, galinhas poedeiras e matrizes). Em função disto, optoutse pela elaboração de uma formulação utilizando as mesmas quantidades de peito e pele para as diferentes aves, em que as composições finais dos nuggets ficassem muito próximas. Kondaiah \& Panda (1992) encontraram em filé de peito de galinhas poedeiras teores próximos dos encontrados neste trabalho, que foram: 72,09; 23,07; 3,42 e 1,21\% para umidade, proteína, gordura e cinzas, respectivamente; bem como os valores encontrados por Hollender et al. (1987) que foi de 72,5; 22,5; 6,7 e 0,93 para umidade, proteína, gordura e cinzas, respectivamente. 
Tabela 14. Composição centesimal dos diferentes filés de peito utilizados na elaboração dos nuggets

\begin{tabular}{lcccc}
\hline & Proteína & Gordura & Umidade & Cinzas \\
\hline Poedeiras & 22,6 & 1,4 & 74,5 & 1,0 \\
Erro padrão & 0,6 & 0,2 & 0,4 & 0,1 \\
Matrizes & 22,7 & 2,1 & 73,9 & 1,0 \\
$\quad$ Erro padrão & 0,7 & 0,4 & 0,5 & 0,1 \\
Frangos & 21,5 & 0,9 & 75,8 & 1,1 \\
Erro padrão & 0,4 & 0,1 & 0,1 & 0,1 \\
\hline
\end{tabular}

\subsubsection{Valor de $\mathrm{pH}$}

Os valores de $\mathrm{pH}$ encontrados neste trabalho (Tabela 12) foram próximos para os filés de peito das três diferentes aves, sendo que estes valores não diferiram significativamente. Os valores de $\mathrm{pH}$ do filé do peito de frango corroboram com os valores de 5,8 - 5,9 encontrados por Beraquet (2000) bem como o valor de 5,96 encontrado por Qiao et al (2001).

Tabela 15. Valores de $\mathrm{pH}$ dos diferentes filés de peito.

\begin{tabular}{lccc}
\hline Matéria-prima & Frango & Matriz & Poedeira \\
\hline $\mathrm{pH}$ & $5,9^{\mathrm{a}}$ & $5,7^{\mathrm{a}}$ & $5,8^{\mathrm{a}}$ \\
Erro padrão & 0,1 & 0,0 & 0,1 \\
\hline
\end{tabular}

Nota: Médias com letras iguais não apresentam diferença significativa, em nível de $95 \%$ de significância.

$\mathrm{O}$ pH da carne exerce uma grande influência na extração, solubilidade e na capacidade das proteínas musculares se ligarem água. A ligação com a água é menor no ponto isoelétrico da miosina e da actina (aproximadamente 5,0). As proteínas não têm capacidade de se ligar no ponto isoelétrico e essa capacidade é aumentada na medida que o $\mathrm{pH}$ se afasta do ponto isoelétrico. Com o aumento do $\mathrm{pH}$ a proteína se torna mais negativamente carregada e uma carga negativa muito alta implica no aumento na força 
de repulsão entre as proteínas dentro do miofilamento o qual subseqüentemente permite a miofibrila intumescer e reter água (Smith, 2001).

\subsubsection{Capacidade de Retenção de Água (CRA)}

Os filés de peito das três diferentes aves não somente não foram estatisticamente diferentes entre si na avaliação da capacidade de retenção de água, como também apresentaram valores diferentes aos encontrados na literatura (Tabela 16).

Tabela 16. Capacidade de retenção de água dos diferentes filés de peito.

\begin{tabular}{cccccc}
\hline \multicolumn{2}{c}{ Frango } & \multicolumn{2}{c}{ Matriz } & \multicolumn{2}{c}{ Poedeira } \\
\hline Média & $\mathrm{EP}^{*}$ & Média & $\mathrm{EP}^{*}$ & Média & $\mathrm{EP}^{*}$ \\
\hline $0,51^{\mathrm{a}}$ & 0,02 & $0,52^{\mathrm{a}}$ & 0,0 & $0,58^{\mathrm{a}}$ & 0,04 \\
\hline
\end{tabular}

Nota: Médias com letras iguais não apresentam diferença significativa, em nível de $95 \%$ de significância. $\mathrm{EP}^{*}=$ Erro Padrão

A propriedade funcional mais benéfica do tecidos musculares para os produtos formatados é sua habilidade de reter água (CRA) e unir os pedaços de tal modo que o produto final tenha textura de um músculo íntegro (Keeton, 2001).

Contreras (1995) encontrou o valor de 0,73 para peito de frango, bem como Hollender et al. (1987) que encontraram o valor de 0,72 para peito de galinhas de descarte. Por outro lado, Bressan (1998) analisando a CRA em peito de frango encontrou o valor de 0,57 ; próximo ao valor de 0,51 encontrado no presente trabalho enquanto Qiao et al (2001) encontraram um valor menor ainda, de 0,43.

Uma das justificativas para os resultados encontrados nesse trabalho serem menores que alguns resultados presentes na literatura pode ser dada em função dos valores de $\mathrm{pH}$ presente nesse experimento, como estes se encontraram próximo do ponto isoelétrico das proteínas, era de se esperar que houvesse uma diminuição na capacidade de retenção de água. Outro fator que aliado ao $\mathrm{pH}$ propiciou a diminuição dos valores da CRA, foi o recongelamento dos filés de peito anterior a análise. As aves vieram congeladas do abatedouro, foram descongeladas para a realização da desossa e os filés 
foram congelados novamente até a realização das análises. Devido a esses fatores houve a formação de cristais de gelo no músculo durante a estocagem congelada reduzindo a CRA, assim como observado por Miller et al. (1980).

\subsubsection{Capacidade de Emulsificação (CE)}

Os valores de capacidade de emulsificação (CE) obtidos neste trabalho ficaram bem diferentes daqueles encontrados na literatura. Isto se deve às adaptações de metodologia que tiveram que ser feitas para viabilizar a realização desta análise. A principal diferença está no fato de os valores serem geralmente expressos em $\mathrm{mL}$ óleo/2,5g amostra e neste trabalho serem expressos em $\mathrm{mL}$ de óleo por 0,5g amostra. Em termos absolutos, os valores aqui encontrados são bem maiores que os citados por diversos autores (Froning et al, 1971; Kondaiah \& Panda, 1987) e conseqüentemente não podem ser comparados.

Tabela 17. Capacidade de emulsificação dos diferentes filés de peito ( $\mathrm{mL}$ óleo/0,5g carne).

\begin{tabular}{cccccc}
\hline \multicolumn{2}{c}{ Frango } & \multicolumn{2}{c}{ Matriz } & \multicolumn{2}{c}{ Poedeira } \\
\hline Média & $\mathrm{EP}^{*}$ & Média & $\mathrm{EP}^{*}$ & Média & $\mathrm{EP}^{*}$ \\
\hline $79^{\mathrm{a}}$ & 2,8 & $75^{\mathrm{a}}$ & 0,4 & $75^{\mathrm{a}}$ & 1,6 \\
\hline
\end{tabular}

Nota: Médias com letras iguais não apresentam diferença significativa, em nível de $95 \%$ de significância. $\mathrm{EP}^{*}=$ Erro Padrão

Conforme mostrado na Tabela 17, observa-se que, apesar do peito de frango ter apresentado uma CE ligeiramente maior, não houve diferenças significativas entre as três aves, verificando que não houve diferença entre as concentrações de proteínas solúveis dentre as espécies de aves analisadas. Segundo Acton \& Saffle (1972), a concentração de proteínas solúveis afetam significativamente o volume do óleo emulsificado e proteínas solúveis em baixas concentrações são mais eficientes em emulsificar o óleo que em altas concentrações. 
Os valores de capacidade de emulsificação encontrados nesse trabalho indicam que o músculo do filé de peito de galinha pode ser utilizado como matéria-prima na elaboração de produtos emulsionados. Tal propriedade é extremamente importante na qualidade do produto final de modo que este retenha água, gordura e outros nutrientes e seja estável após o cozimento.

\subsection{Análise sensorial dos nuggets}

Os nuggets foram avaliados quanto à aceitação, onde se analisou de uma forma geral o sabor, cheiro, dureza da carne e suculência; bem como a intenção de compra desses produtos pelos consumidores.

Avaliourse também os consumidores de modo a se obter um perfil dos mesmos em relação à classe econômica, sexo, faixa etária e a frequiência de consumo de produtos empanados tipo nuggets.

\subsubsection{Classe econômica dos consumidores}

É possível observar através da Figura 16 que mais da metade $(68,5 \%)$ dos provadores pertenciam às classes $\mathrm{A}$ e $\mathrm{B}$, diferentemente da distribuição encontrada na grande São Paulo segundo a ANEP (2001), onde as classes A e B somaram quase a metade do valor encontrado nesse trabalho, o equivalente a $33 \%$, sendo este dividido em $1 \%, 6 \%, 10 \%$ e $16 \%$ para as classes $\mathrm{A} 1, \mathrm{~A} 2, \mathrm{~B} 1$ e $\mathrm{B} 2$ respectivamente.

Essa diferença nos resultados indica que a região analisada possui um alto poder aquisitivo e consequientemente a possibilidade de haver um consumo mais acentuado de produtos com valor agregado. 


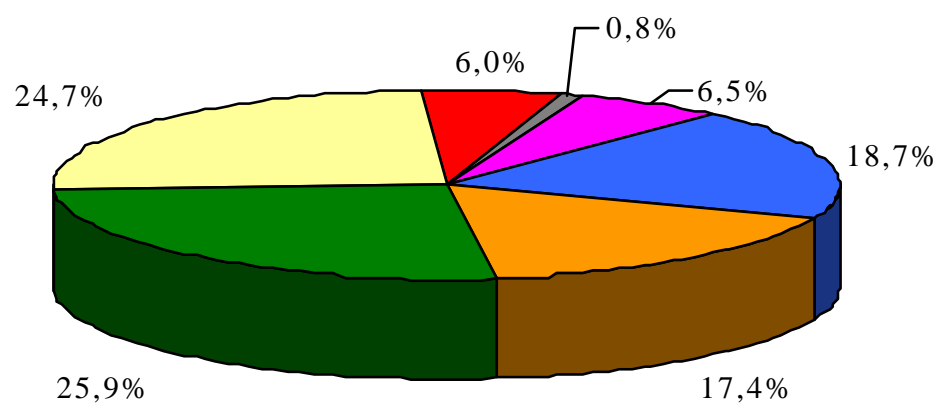

$\square \mathrm{A} 1 \square \mathrm{A} 2 \square \mathrm{B} 1 \square \mathrm{B} 2 \square \mathrm{C} \square \mathrm{D} \square \mathrm{E}$

Figura 16 - Distribuição da classe econômica dos consumidores.

\subsubsection{Sexo e faixa etária dos consumidores}

Como pode ser observada na Figura 17, a grande maioria dos consumidores entrevistados pertenciam ao sexo feminino. Essa diferença, porém, acaba sendo pequena, quando se analisa isoladamente a porcentagem de consumidores situada nas faixas etárias, menor que 20 e maior que 60 anos.

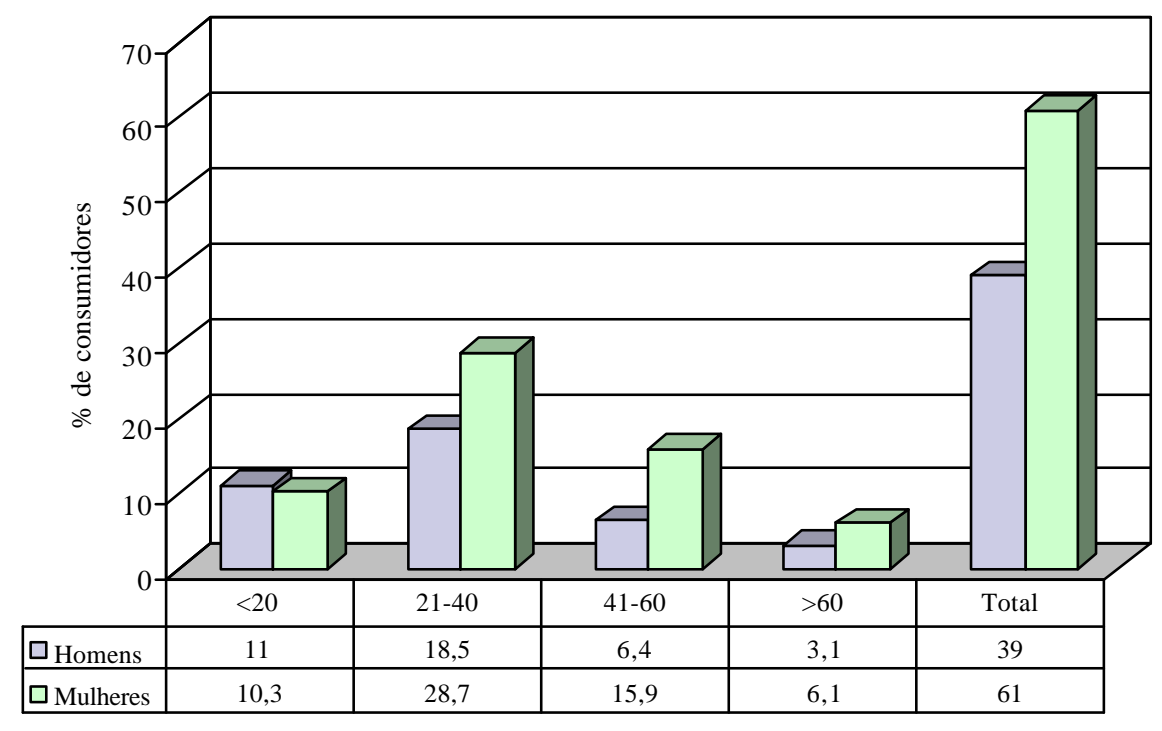

Faixa etária

Figura 17 - Sexo e faixa etária dos consumidores 
A grande diferença entre os sexos das pessoas entrevistadas ocorreu na faixa etária onde se situavam as pessoas economicamente ativas, ou seja, entre os 21 e 60 anos. Esses consumidores significaram $69,5 \%$ do total entrevistado, sendo $44,6 \%$ do sexo feminino e $24,9 \%$ do sexo masculino. Deste modo, intensifica-se a idéia de que as mulheres, apesar de trabalharem fora, ainda são as grandes responsáveis pelo abastecimento alimentar da família, justificando desse modo o aumento do consumo dos produtos de conveniência nos últimos anos.

\subsubsection{Frequiência de consumo e classe econômica dos consumidores}

De acordo com a Figura 18 os produtos de conveniência são consumidos quase que de modo semelhante por quase todas as classes econômicas, exceto pelas classes $\mathrm{D}$ e E. Segundo a amostragem entrevistada, a classe B2 é a que mais consome com 25,1\% seguida das classes A2, C e B1 com 21,9\%; 21,1\% e 18,7\% respectivamente. Observour se que a classe A1, de maior poder econômico, consumiu apenas 9,2\%, um pouco mais que o dobro que consumiu a classe $\mathrm{D}, 3,6 \%$. 


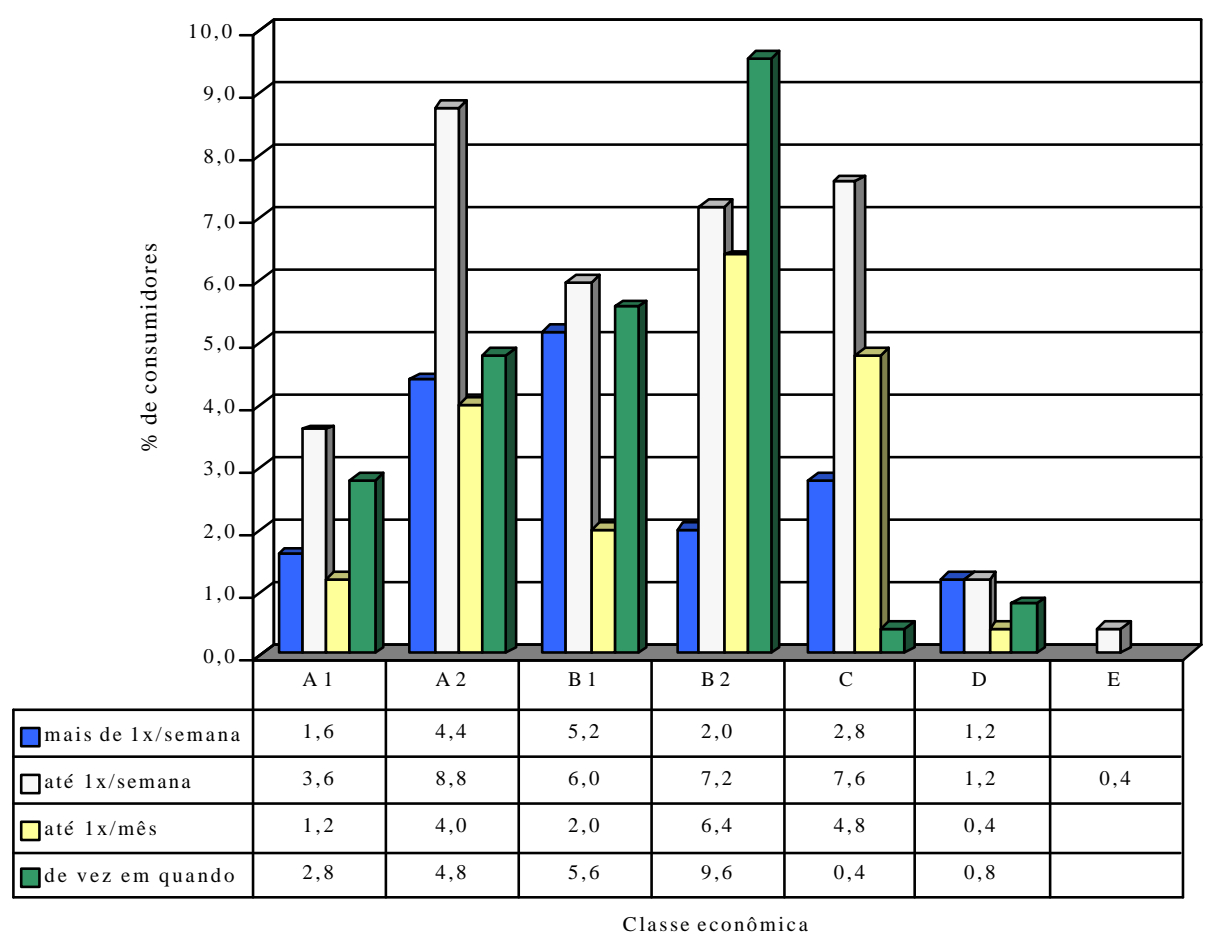

Figura 18 - Frequiência de consumo em relação à classe econômica dos consumidores.

Comparando-se a frequiência em função da classe econômica, observa-se que não necessariamente a relação de maior poder aquisitivo implicou no maior consumo de nuggets, tal fato pode ser observado quando se compara o consumo de até uma vez por semana da classe A2 (8,8\%) com o da classe C (7,6\%), bem como quando se compara o consumo de mais de uma vez por semana da classe A1 $(1,6 \%)$ com o consumo da classe D $(1,2 \%)$.

Esses resultados levam a crer que o fator preço não é uma questão primordial na escolha de produtos, na medida que estes trazem praticidade para o dia a dia.

Se esses resultados forem discutidos sem a influência das classes econômicas, pode-se concluir que 18,8\% dos consumidores afirmaram consumir nuggets pelo menos 1 vez por mês sendo que 34,8\% consomem nuggets pelo menos uma vez por semana. Isso implica na popularidade desse tipo de produto e sua importância no cardápio alimentar. 


\subsubsection{Aceitação sensorial}

A análise das médias de aceitação dos provadores (Tabela 18) indicou, contrariamente do que se havia imaginado, que não houve diferença entre os dois tratamentos (matriz e poedeira) quando comparado com o controle (frango), em nível de 5\% de significância. Como a carne de galinha possui uma textura mais dura, é menos suculenta e possui um sabor intenso, imaginava-se inicialmente que os consumidores detectassem diferença entre as amostras analisadas. As médias de aceitação para frango, poedeira e matriz foram respectivamente 6,$4 ; 6,3$ e 6,3. Isto significa que, além de não terem sido detectadas diferenças entre as amostras, todas foram muito bem aceitas entre os provadores, ficando estes valores na escala entre o "gostei muitíssimo" e o "gostei moderadamente".

Tabela 18. Médias das notas de aceitação dos nuggets.

\begin{tabular}{lccc}
\hline Matéria-prima & Frango & Poedeira & Matriz \\
\hline Aceitação sensorial & $6,4^{\mathrm{a}}$ & $6,3^{\mathrm{a}}$ & $6,3^{\mathrm{a}}$ \\
\hline
\end{tabular}

Nota: Médias com letras iguais não apresentam diferença significativa, em nível de $95 \%$ de significância.

$\mathrm{Na}$ Figura 19 está apresentada a distribuição das notas atribuídas pelos consumidores aos produtos e como pode ser observado, os três tipos de nuggets foram aprovados por mais de $80 \%$ dos consumidores entrevistados com classificação entre o "gostei muitíssimo" e "gostei moderadamente".

No espaço reservado para os comentários dos nuggets na ficha sensorial, os consumidores foram extremamente contraditórios referentes aos atributos avaliados como, sabor, odor, dureza da carne e suculência, não detectando a diferença entre os diferentes tipos de carne independentemente da classe social. Os principais atributos citados pelos consumidores em relação ao que mais gostou nos produtos foram a suculência, sabor, maciez, odor e a textura sendo esses, citados nos três tipos de nuggets (frango, poedeira e matriz). Entre os atributos que menos atraíram os consumidores foram a suculência e o cheiro, independentemente da matéria-prima utilizada. $\mathrm{Na}$ 
tentativa de detectar diferença entre os produtos, muitos consumidores fizeram comentários em relação ao tempero e ao teor de sal, porém essas observações não foram factíveis já que os três tipos de nuggets apresentaram a mesma formulação. Deste modo pode-se concluir que não houve uma diferença específica entre os produtos analisados.

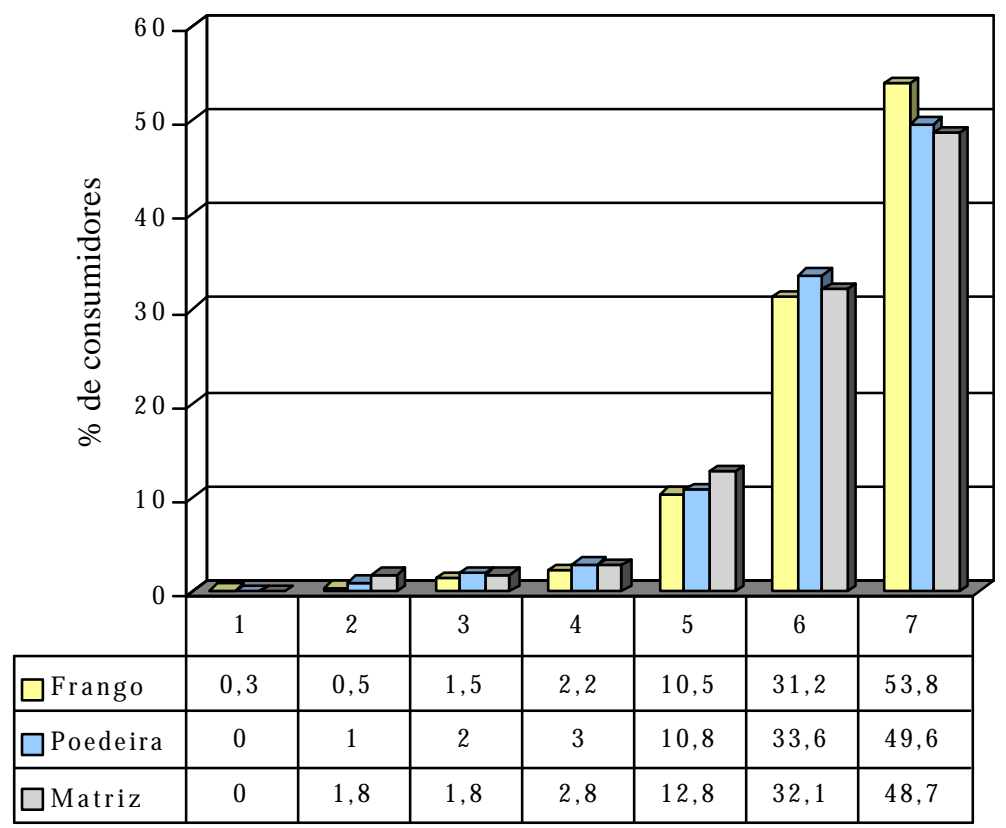

Escala Sensorial

Figura 19 - Distribuição dos consumidores em relação ao índice de aceitação dos nuggets ( 1 - desgostei muitíssimo e 7 - gostei muitíssimo).

Os dados obtidos estão de acordo com trabalho realizado por Rouselle et al (1984). Estes pesquisadores não encontraram diferenças significativas entre nuggets feitos com carne de peito de frango e de galinhas poedeiras aplicando o teste de consumidor. Hasiak \& Baker (1969) compararam "steaks", que são produtos reestruturados e empanados semelhantes aos nuggets, feitos com carnes de peito e/ou de coxas de galinhas pesadas (matrizes), galinhas Leghorn (poedeiras) e frangos. Estes autores trabalhando com uma equipe treinada de provadores, encontraram diferenças 
significativas na textura, na suculência e no sabor dos "steaks" de filé de peito. Os "steaks" de frango foram mais macios e mais suculentos que os das duas galinhas. Já no sabor, o "steak" de frango recebeu nota melhor do que o de poedeira, mas igual ao de matriz. No entanto, neste mesmo trabalho, quando foi solicitado aos provadores para indicar a amostra preferida, os "steaks" de peito das três diferentes aves não apresentaram diferenças significativas.

\subsubsection{Intenção de compra}

As médias obtidas no teste de intenção de compra com os três tipos de nuggets avaliados (frango, galinha poedeira e galinha matriz) estão apresentadas na Tabela 19. Observa-se que os nuggets obtiveram as mesmas notas, ficando entre os critérios certamente compraria (5) e provavelmente compraria (4) (Anexo). Deste modo, pode-se notar a mesma tendência observada na análise de aceitação sensorial, onde os diferentes tipos de nuggets analisados obtiveram não apenas notas muito semelhantes entre si, como também ficaram próximos da nota máxima.

Tabela 19. Médias das notas de intenção de compra dos nuggets

\begin{tabular}{lccc}
\hline Matéria-prima & Frango & Poedeira & Matriz \\
\hline Intenção de compra & $4,4^{\mathrm{a}}$ & $4,4^{\mathrm{a}}$ & $4,4^{\mathrm{a}}$ \\
\hline
\end{tabular}

Nota: Médias com letras iguais não apresentam diferença significativa, em nível de $95 \%$ de significância. 
A Figura 20 apresenta a distribuição dos consumidores na avaliação de intenção de compra dos nuggets.

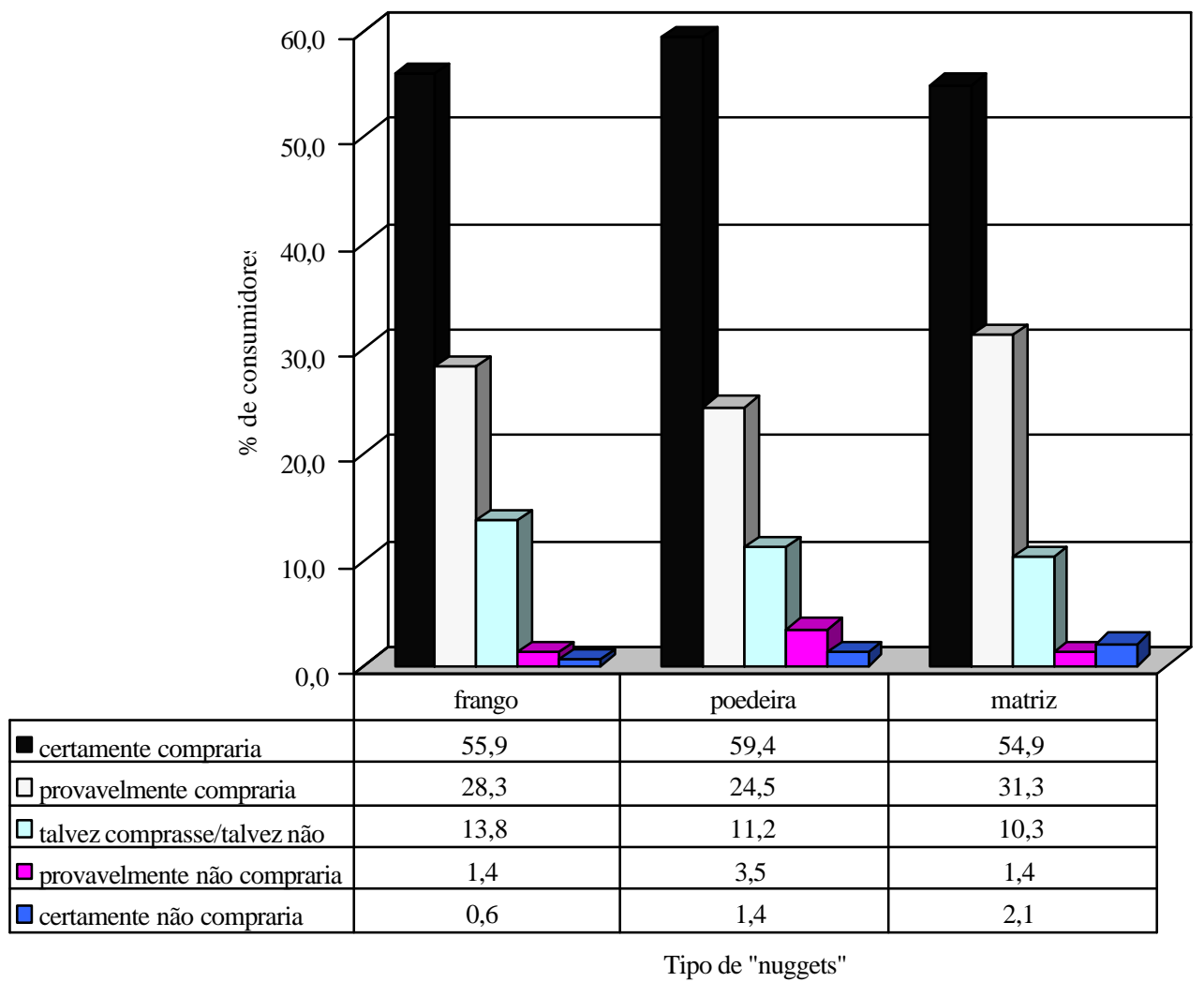

Figura 20 - Distribuição dos consumidores em relação à intenção de compra dos nuggets.

Através da Figura acima, observa-se que mais de 50\% dos entrevistados certamente comprariam os produtos, intensificando, deste modo, a idéia de que não foi detectada diferença entre os produtos, já que a distribuição dos consumidores entre os critérios de avaliação é muito próxima entre si para os três tipos de nuggets.

Os resultados encontrados nesse trabalho corroboram com Sloan (1999), embora tal trabalho tenha avaliado o mercado consumidor norte americano. Segundo Sloan (1999) aproximadamente 50\% dos adultos ingerem alimentos enquanto assistem televisão e gastam aproximadamente sete horas por dia nessa última atividade, o que equivale a aproximadamente cinqüenta horas semanais. Deste modo há uma procura por 
alimentos nutritivos e de rápido preparo, tornando o mercado de alimentos prontos ainda mais forte.

No Brasil, embora não haja uma pesquisa semelhante, sabe-se que é grande o número de mulheres chefes de família e isso implica em um menor tempo dedicado ao preparo dos alimentos e uma maior necessidade de produtos de conveniência. 


\section{CONCLUSÕES}

Com base nos resultados experimentais obtidos, pode-se concluir que:

- Os resultados da análise de caracterização microbiológica indicaram que a CMS obtida estava dentro dos padrões exigidos pela legislação Brasileira

- O potencial bactericida do nitrito foi reduzido na CMS em função do elevado $\mathrm{pH}$.

- Os tratamentos químicos com nitrito e nitrito mais eritorbato não mostraram melhoria na vida útil das CMSs congeladas com relação à estabilidade microbiológica

- Como não houve diferença entre os tratamentos, pode-se afirmar que o efeito do congelamento foi o principal fator na redução da carga microbiana; e a sobrevivência dos microrganismos em temperatura de $-18^{\circ} \mathrm{C}$ enfatizou a importância da aplicação dos princípios das Boas Práticas de Fabricação, assegurando deste modo uma carga microbiana inicial baixa.

- Os filés de peito de galinhas matrizes e poedeiras apresentaram teores de composição centesimal dentro das faixas normalmente encontradas, não diferindo muito dos valores encontrados para o filé de frango, exceto para o teor de gordura.

- Os valores de $\mathrm{pH}$ foram semelhantes aos valores normalmente encontrados em carne de peito.

- Não houve diferença entre os valores de capacidade de retenção de água na carne de peito das três diferentes aves. 
- Não houve diferença entre os valores de capacidade de emulsificação ra carne de peito das três diferentes aves.

- A maioria dos consumidores entrevistados pertencia às classes $\mathrm{A}$ e $\mathrm{B}$, sendo a grande maioria do sexo feminino.

- A frequiência de consumo não está estritamente ligada a classe econômica dos entrevistados.

- A elaboração de nuggets com carne de peito de galinha de descarte, tanto de matrizes e corte quanto de poedeiras comerciais, resultou em produtos com qualidade sensorial tão boa quanto a dos nuggets elaborados com filé de peito de frango. Assim, a elaboração de nuggets pode representar uma boa alternativa para a utilização de filés de peito de galinhas de descarte, agregando maior valor a estas aves ao final do ciclo de postura. 
ANEXO 
ANEXO - Ficha para avaliação sensorial de nuggets.

\begin{tabular}{|l|l|l|l|l|l|}
\hline \multicolumn{1}{|c|}{ Fale um pouco sobre vocế: } & NÃO TEM & \multicolumn{1}{l|}{ TEM } & 2 & 3 & $4 \mathrm{ou}+$ \\
\hline Televisão em cores & & & & & \\
\hline Rádio & & & & & \\
\hline Banheiro & & & & & \\
\hline Automóvel & & & & & \\
\hline Empregada mensalista & & & & & \\
\hline Aspirador de pó & & & & & \\
\hline Máquina de lavar & & & & & \\
\hline Vídeo-cassete & & & & & \\
\hline Geladeira & & & & & \\
\hline Freezer & & & & & \\
\hline
\end{tabular}

Grau de Instrução do chefe da família

\begin{tabular}{|l|l|}
\hline Analfabeto /Primário incompleto & \\
\hline Primário completo / Ginasial incompleto & \\
\hline Ginasial completo / Colegial incompleto & \\
\hline Colegial completo / Superior incompleto & \\
\hline Superior completo & \\
\hline
\end{tabular}

Faixa de idade que você possui:

( ) menos de $20 \operatorname{anos}($ ) de 21 a 40 anos ( ) de 41 a 60 anos ( ) acima de 60 anos

Sexo- F( ) M( )

Com que freqüência você consome nuggets?

( ) mais que 1 vez por semana ( ) até 1 vez por semana ( ) até 1 vez por mês ( ) de vez em quando

Avalie os nuggets de uma FORMA GERAL (sabor, cheiro, dureza da carne, suculência) e marque com um X:

Amostras

7 GOSTEI MUITÍSSIMO

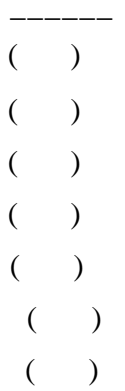

$\left(\begin{array}{l}( \\ (\end{array}\right)$
$(\quad)$
$(\quad)$
$(\quad)$
$(\quad)$
$(\quad)$

$\left(\begin{array}{c}( \\ (\end{array}\right)$
$(\quad)$
$(\quad)$
$(\quad)$
$(\quad)$
$(\quad)$

Descreva o que você mais gostou nesses produtos (sabor, cheiro, dureza da carne, suculência)

Descreva o que menos gostou nesses produtos (sabor, cheiro, dureza da carne, suculência)

Se estes nuggets estivessem à venda e o preço não fosse problema, você:

Amostras

5 CERTAMENTE COMPRARIA

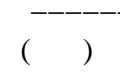

4 PROVAVELMENTE COMPRARIA

3 TALVEZ COMPRASSE / TALVEZ NÃO ( )

2 PROVAVELMENTE NÃO COMPRARIA ( )

1 CERTAMENTE NÃO COMPRARIA （ ) 


\section{REFERÊNCIAS BIBLIOGRÁFICAS}

ACTON, J.C.; SAFFLE, R.L Emulsifying capacity of muscle protein: phase volumes at emulsion collapse. Journal of Food Science, v.37, n.3, p.804-806, 1972.

AGÊNCIA NACIONAL DE VIGILÂNCIA SANITÁRIA - ANVISA. Portaria n¹004, de 11 de dezembro de 1998. http://www.anvisa.gov.br/legis/portarias/1004_98.htm (16 jul. 2003)

AGÊNCIA NACIONAL DE VIGILÂNCIA SANITÁRIA - ANVISA. Resolução RDC $\mathbf{n}^{0} 12$, de 12 de janeiro de 2001. http://www.anvisa.gov.br/legis/resol/12_01rdc.htm (11 dez. 2002)

AJUYAH, A.O.; HARDIN, T.R.; CHEUNG, K.; SIM, J.S. Yield, lipid cholesterol and fatty acid composition of spent hens fed full-fat oil seeds and fishmeal diets. Journal of Food Science, v.57, n.2, p.338-341, 1992.

ASSOCIAÇÃO NACIONAL DE EMPRESAS DE PESQUISA - ANEP. http://www.anep.org.br (09 maio 2001)

AYRES, J.C.; OGILVY, W.S.; STEWART, G.F. Postmortem changes in stored meats. I. Microorganisms associated with development of slime on eviscerated cut-up poultry. Food Technology, v.4, p.199-205, 1950. 
BAKER, R.C.; O'BRIEN, S.W.; GOSSETT, P.W. Development and evaluation of chicken burger formulations and effect of beating time incorporating underutilized poultry meat. Poultry Science, v.63, n.5, p.938-948, 1984.

BAKER, R.C.; BRUCE, C.A. Further processing of poultry. In: MEAD, G.C. (Ed.). Processing of poultry. London: Chapman \& Hall, 1995. cap.8, p.251-282.

BARBUT, S. Microbiology and sanitation. In: Poultry products processing: an industry guide. Boca Raton: CRC Press, 2002a. cap.11, p.315-377.

BARBUT, S. Poultry products: formulations and gelation. In: Poultry products processing: an industry guide. Boca Raton: CRC Press, 2002b. cap.9, p.249-289.

BAYNE, H.G.; MICHENER, H.D. Growth of Staphylococcus aureus and Salmonella on frankfurters with and without sodium nitrite. Applied Microbiology, v.30, n.5, p.844-849, 1975.

BERAQUET, N.J. Carne mecanicamente separada de aves. In: SEMINÁRIO E CURSO TEÓRICO-PRÁTICO, Campinas, 2000. Agregando valor à carne de aves. Campinas: ITAL, 2000. 1v.

BERGDOLL, M.S. Staphylococcal intoxication. In: RIEMANS, H.S.; BYRAN, F. Foodborne infections and intoxications. New York: Academic Press, 1979. cap.9, p.444-490.

BIJKER, P.G.H.; LOGTESTIJN, J.G. van; MOSSEL, D.A.A. Bacteriological quality assurance (BQA) of Mechanically Deboned Meat (MDM). Meat Science, v.20, n.4, p.237-252, 1987. 
BRASIL. Ministério da Agricultura e Abastecimento. Secretaria de Defesa Agropecuária. Instrução Normativa $\mathbf{n}^{0}$ 4, de 31 de março de 2000. http://www.agricultura.gov.br/das/dipoa/in_04_2000.htm (16 jul. 2003)

BRESSAN, M.C. Efeitos dos fatores pré e pós abate sobre a qualidade da carne de peito de frango. Campinas, 1998. 201p. Tese (Doutorado) - Faculdade de Engenharia de Alimentos, Universidade de Campinas.

BUCHANAN, R.L.; SOLBERG, M. Interaction of sodium nitrate, oxygen and $\mathrm{pH}$ on growth of Staphylococcus aureus. Journal of Food Science, v.37, n.1, p.81-85, 1972.

BUCHMAN, G.W.; HANSEN, J.N. Modification of membrane sulfhydryl groups in bacteriostatic action of nitrite. Applied and Environmental Microbiology, v.53, n.1, p.79-82, 1987.

BUSHWAY, A.A.; FICKER, N.; JEN, C.W. Effect of nitrite and sorbate on total number of aerobic microorganisms in chicken white and dark meat patties. Journal of Food Science, v.47, n.3, p.858-860,863, 1982.

CAMMACK, R.; JOANNOU, C.L.; CUI, X.Y; MARTINEZ, C.T.; MARAJ, S.R.; HUGHES, M.N. Nitrite and nitrosyl compounds in food preservation. Biochimica et Biophysica Acta, v.1411, p.475-488, 1999.

CARPENTER, C.E.; REDDY, D.S.A.; CORNFORTH, D.P. Inactivation of clostridial ferredoxin and pyruvate-ferredoxin oxidoreductase by sodium nitrite. Applied Environmental Microbiology, v.53, n.3, p.549-552,1987.

CASSENS, R.G. Composition and safety of cured meats in the USA. Food Chemistry, v.59, n.4, p.561-566, 1997. 
CASTELLANI, A.G.; NIVEAN, C.F. Factors affecting the bacteriostatic actions of sodium nitrite. Applied Microbiology, v.3, n.4, p.154-159, 1955.

CHRISTIANSEN, L.N.; TOMPKIN, R.B.; SHAPARIS, A.B. Fate of Clostridium botulinum in perishable canned cured meat at abuse temperature. Journal of Food Protection, v.41, n.5, p.354-355, 1978.

CHRISTOPHERSEN, J. Effects of freezing and thawing on the microbial population of foodstuffs. In: HAWTHORN, J.; ROLFE, E.J. (Ed.). Low temperature biology of foodstuffs. Oxford: Pergamon Press, 1968. p.251-269.

CONTRERAS, C.J.C. Efeito do atordoamento elétrico, da estimulação elétrica e da desossa a quente na qualidade da carne do peito (músculo Pectoralis major) de frango. Campinas, 1995. 155p. Tese (Doutorado) - Faculdade de Engenharia de Alimentos, Universidade de Campinas.

COX, N.A.; BAILEY, J.S. Pathogens associated with processed poultry. In: CUNNINGHAM, F.E.; COX, N.A. The microbiology of poultry products. San Diego: Academic Press, 1987. cap.10, p.293-316.

CUNNIF, P. (Ed.). Official methods of analysis of AOAC International. 16.ed. Arlington: AOAC International, 1998. cap.16, p.26-27.

DELAZARI, I. Microbiologia de alimentos congelados. I. Efeito do congelamento sobre os microrganismos. Boletim do ITAL, v.17, n.1, p.15-30, 1980.

DUTCOSKY, S.D. Métodos sensoriais. In: Análise sensorial de alimentos. Curitiba: Champagnat, 1996. cap.5, p.25-85. 
ELLIOT, R.P.; STRAKA, R.P. Rate of microbial deterioration of chicken meat at $2^{\circ} \mathrm{C}$ after freezing and thawing. Poultry Science, v.43, p.81-86, 1964.

ESSARY, E.O. Moisture, fat, protein and mineral content of mechanically deboned poultry meat. Journal of Food Science, v.44, n.4, p.1070-1073, 1979.

FIELD, R.A. Mechanically separated meat, poultry and fish. In: PEARSON, A.M.; DUTSON, T.R. (Ed.). Edible meat by-products: advances in meat research. London: Elsevier Applied Science, 1988. v.5. cap.4, p.83-126.

FIGUEIREDO, E.A.P. Avicultura de corte ou de postura ? http://www.acrimat.com.br/palestras/aves02.htm (06 jun. 2002)

FRONING, G.W. Mechanical deboning of poultry and fish. Advances in Food Research, v.27, p.109-147, 1981.

FRONING, G.W.; NEELAKANTAN, S. Emulsifying characteristics of prerigor and postrigor poultry muscle. Poultry Science, v.50, n.3, p.839-845, 1971.

FRONING, G.W.; McKEE, S.R. Mechanical separation of poultry meat and its use in products. In: SAMS, A. R. (Ed.). Poultry meat processing. Boca Raton: Lewis Publishers, 2001. cap.14, p.243-256.

FUNG, D.Y.C. Types of microorganisms. In: CUNNINGHAM, F.E.; COX, N.A. The microbiology of poultry products. San Diego: Academic Press, 1987. cap.2, p.527.

GARCIA, C.E.R.; YOUSSEF, E.Y.; PINHEIRO, J.W.; MASSAMI, S. Salga de galinhas de descarte: alternativa simples e rentável ao produtor e consumidor. Revista Nacional da Carne, n.290, p.26-28, 2001. 
GILL, C.O.; NEWTON, K.G. The ecology of bacterial spoilage of fresh meat at chill temperatures. Meat Science, v.2, n.3, p.207-217, 1978.

GILL, C.O.; NEWTON, K.G. Growth of bacteria on meat at room temperatures. Journal of Applied Bacteriology, v.49, n.2, p.315-323, 1980.

GRAU, R.; HAMM, R. Eine einfache method bestimmung der waserbinding in muskel. Naturwessenchaft, v.40, n.1, p.29-33, 1953.

GRUNDEN, L.P.; MacNEIL, J.H.; DIMICK, P.S. Poultry product quality: chemical and physical characteristics of mechanically deboned poultry meat. Journal of Food Science, v.37, n.2, p.247-249, 1972.

HAMM, R. Functional properties of the myofibrillar system and their measurements. In: BECHTEL, P.J. Muscle as food. London: Academic Press, 1986. cap.4, p.135199.

HAQ, A.; WEBB, N.B.; WHITFIELD, J.K.; HOWELL, J.; BARBOUR, B.C. Measurement of sausage emulsion stability by electrical resistance. Journal of Food Science, v.38, n.6, p.1224-1227, 1973.

HASIAK, R.J.; BAKER, R.C. The development of chicken steak from breast and thigh meat. Poultry Science, v.47, n.5, p.1526-1531, 1969.

HASIAK, R.J.; CHAVES, J.; SEBRANEK, J.; KRAFT, A.A. Effect of sodium nitrite and sodium eritorbate on the chemical, sensory and microbiological properties of water-add turkey ham. Poultry Science, v.63, n.7, p.1364-1371, 1984. 
HOFFMANN, K.; HAMM, R.; BLUCHEL, E. Neus über die bestimung der wasserbinding des nut hielf filterpaperpremethods. Fleishwirtschaft, v.62, n.1, p.87-94, 1982.

HOLLENDER, R.; MacNEIL, J.H.; MAST, M.G. Effect of fragmentation and formulation on the quality of patties made from restructured spent layer meat. Journal of Food Science, v.52, n.2, p.290-293, 1987.

JANSSEN, D.W.; BUSTA, F.F. Influence of milk components on the injury, repair of injury and death of Salmonella anatum cells subjected to freezing and thawing. Applied Microbiology, v.26, n.5, p.725-732, 1973.

KEETON, J.T. Formed and emulsion products. In: SAMS, A.R. (Ed.). Poultry meat processing. Boca Raton: Lewis Publishers, 2001. cap.12, p.195-226.

KONDAIAH, N.; PANDA, B. Effect of hot and cold boning of spent hens on carcass components and functional properties of frozen meat. International Journal of Food Science and Technology, v.22, n.4, p.413-416, 1987.

KONDAIAH, N.; PANDA, B. Processing and utilization of spent hens. World's Poultry Science Journal, v.48, n.2, p.255-268, 1992.

KONDAIAH, N. Products from spent hen. Poultry International, v.49, n.1, p.46-47, Aug. 1993.

KRAFT, A.A. Microbiology of poultry products. Journal of Milk and Food Technology, v.34, n.1, p.23-29, 1971. 
KUMAR, S.; PEDERSEN-WISMER, J.; CASPERSEN, C. Effect of raw materials, deboning methods and chemical additives on microbial quality of mechanically deboned poultry meat during frozen storage. Journal of Food Science and Technology, v.23, n.4, p.217-220, 1986.

LEE, T.G.; WILLIAMS, S.K.; SOLAN, D.; LITTELL, R. Development and evaluation of a chicken breakfast sausage manufactured with mechanically deboned chicken meat. Poultry Science, v.76, n.3, p.415-421, 1997.

LEMOS, A.L.S.C. Valor agregado e conveniência para produtos cárneos. In: SEMINÁRIO E CURSO TEÓRICO-PRÁTICO, Campinas, 2000. Agregando valor a carne de aves. Campinas: ITAL, 2000. 1v.

LESIOW, T.; SKRABKBLOTNICKA, T. Changes occurring in proteins during the frozen storage of duck breast muscle at $-18^{\circ} \mathrm{C}$ and $-2^{\circ} \mathrm{C}$. 3. Report: changes in emulsifying properties. Archiv Fur Geflugelkunde, v.52, n.5, p.173-176, 1988.

LILLARD, H.S. Occurrence of Clostridium perfringens in broiler processing and further processing operations. Journal of Food Science, v.36, n.7, p.1008-1010, 1971.

LILLARD, H.S. Effect of freezing on incidence and levels of Clostridium perfringens in mechanically deboned chicken meat. Poultry Science, v.56, n.6, p.2052-2055, 1977.

LIN, H.S.; SEBRANEK, J.G.; GALLOWAY, D.E.; LIND, K.D. Effect of sodium erythorbate and packaging conditions on color stability of sliced bologna. Journal of Food Science, v.45, n.1, p.115-118, 121, 1980. 
LOWRY, P.D.; GILL, C.O. Microbiology of frozen meat and meat products. In: ROBINSON, R.K. Microbiology of frozen food London: Elsevier Applied Science, 1985. cap.4, p.109-168.

MARRIOT, N.G.; LECHOWICH, R.V.; PIERSON, M.D. Use of nitrite and nitritesparing agents in meats: a review. Journal of Food Protection, v.44, n.11, p.881$885,1981$.

MAXCY, R.B.; FRONING, G.W.; HARTUNG, T.E. Microbial quality of ground poultry meat. Poultry Science, v.52, n.2, p.486-489, 1973.

McMINDES, M.K.; SIEDLER, A.J. Nitrite mode of action: inhibition of yeast pyruvate decarboxylase (E.C. 4.1.1.1) and clostridial pyruvate:ferredoxin oxidoreductase (E.C. 1.2.7.1) by nitric oxide. Journal of Food Science, v.53, n.3, p.917-919-931, 1988.

MEAD, G.C. Hygiene problems and control of process contamination. In: Processing of poultry. London: Chapman \& Hall, 1995. cap.6, p.183-220.

MEAD, G.C.; ADAMS, B.W. A selective medium for the rapid isolation of Pseudomonads associated with poultry meat spoilage. British Poultry Science, v.18, n.6, p.661-667, 1977.

MEYER, J. Comparison of carbon monoxide, nitric oxide and nitrite as inhibitors of the nitrogenase from Clostridium pasteurianum. Archives of Biochemistry and Biophysics, v.210, n.1, p.246-256, 1981.

MILLER, A.J.; ACHERMAN, S.A.; PALUMBO, S.A. Effects of frozen storage on functionality of meat for processing. Journal of Food Science, v.45, n.6, p.14661471, 1980. 
MORAN, D.M.; TANNENBAUM, S.R.; ARCHER, M.C. Inhibitor of Clostridium perfringens formed by heating sodium nitrite in a chemically defined medium. Applied Microbiology, v.30, n.5, p.838-843, 1975.

NAGEL, C.W.; SIMPSON, K.L.; VAUGHN, R.H.; STEWART, G.F. Microorganisms associated with spoilage of refrigerated poultry. Food Technology, v.14, n.1, p.2123,1960

NURMI, E.; RING, C. Production of hygienically justifiable mechanically recovered meat. Fleischwirtscaft International, v.2, n.1, p.21-22, 1999.

O'LEARY, V.; SOLBERG, M. Effect of sodium nitrite inhibition on intracellular thiol groups and on the activity of certain glycolytic enzymes in Clostridium perfringens. Applied and Environmental Microbiology, v.31, n.2, p.208-212, 1976.

OLSON, V.; SWAMINATHAN, B.; STADELMAN, W.J. Reduction in numbers of Salmonella typhimurium on poultry parts by repeated freeze-thaw treatments. Journal of Food Science, v.46, n.5, p.1323-1326, 1981.

OSTOVAR, K.; MacNEIL, J.H.; O’DONNEL, K. Poultry product quality. 5. Microbiological evaluation of mechanically deboned poultry meat. Journal of Food Science, v.36, n.7, p.1005-1007, 1971.

OWENS, C. M. Coated poultry products. In: SAMS, A.R. Poultry meat processing. Boca Raton: Lewis Publishers, 2001. cap.14, p.227-242.

PARDI, M.C.; SANTOS, I.F.; SOUZA, E.R.; PARDI, H.S. Processamento tecnológico da carne: as emulsões. In: Ciência, higiene e tecnologia da carne. Goiânia: UFG/EDUFF, 1994. p.799-802. 
POLLONIO, M.A.R. Estudo das propriedades funcionais das proteínas miofibrilares e oxidação lipídica de carne de frango mecanicamente desossada. Campinas, 1994. 141p. Tese (doutorado) - Faculdade de Engenharia de Alimentos, Universidade de Campinas.

QIAO, M.; FLETCHER, D.L.; SMITH, D.P.; NORTHCUTT, J.K. The effect of broiler breast meat color on $\mathrm{pH}$, moisture, water hold capacity and emulsification capacity. Poultry Science, v.80, n.6, p.676-680, 2001.

RANKEN, M.D. The use of ascorbic acid in meat processing. In: COUNSELL, J.N.; HORNIG, D.H. Vitamin C (ascorbic acid). London: Applied Science Publ., 1981. cap.7, p.105-122.

RIHA, W.; SOLBERG, M. Clostridium perfringens growth in a nitrite containing defined medium sterilized by heat or filtration. Journal of Food Science, v.40, n.2, p.443-445, 1975.

RISIVIK, E. Sensory properties and preferences. Meat Science, v.36, n.1, p.67-77, 1994.

ROBERTS, T.A.; DAINTY, R.H. Nitrite and nitrate as food additives. In: HILL, M.J. (Ed.). Nitrate and nitrite in foods and water. New York: Ellis Horwood, 1991. cap.6, p.113-130.

ROBERTS. T.A.; GIBSON, A.; ROBINSON, A. Factors controlling the growth of Clostridium botulinum types A and B in pasteurized cured meats. I. Growth in pork slurries prepared from low $\mathrm{pH}$ meat $(\mathrm{pH}$ range 5,5-6,3). Journal of Food Technology, v.16, n.3, p.267-281, 1981. 
ROLAND, L.M.; SEIDEMAN, S.C.; DONNELLY, L.S.; QUENZER, N.M. Physical and sensory properties of chicken patties made with varying proportions of white and dark spent fowl meat. Journal of Food Science, v.46, n.3, p.834-837, 1981.

ROUSELLE, J.R.; SEACAT, K.; KIEME, A.I.; STADELMAN, W.J. Utilizing flakecut spent fowl meat in chicken patties. Poultry Science, v.63, n.5, p.932-937, 1984.

SCHNELL, P.G.; VADEHRA, D.V.; HOOD, L.R.; BAKER, R.C. Ultra-structure of mechanically deboned poultry meat. Poultry Science, v.53, n.1, p.416-419, 1974.

SEIDEMAN, S.C.; DURLAND, P.R.; QUENZER, N.M.; CARLSON, C.W. Utilization of spent fowl muscle in the manufacture of restructured steaks. Poultry Science, v.61, n.6, p.1087-1093, 1982.

SHANK, J.L.; SILLIKER, J.H.; HARPER, R.H. The effect of nitric oxide on bacteria. Applied Microbiology, v.10, n.3, p.185-189, 1962.

SILVA, R.Z.M. Technologie und mikrobiologie voraussetzung zur herstellung sicherer und stabiler rohpökelwaren aus geflügelfleish. Berlim, 1994. 113p. Tese (Doutorado) - Technische Universität Berlin.

SILVEIRA, E.T.F. Produção de produtos empanados de frango. In: INDUSTRIALIZAÇÃO DA CARNE DE FRANGO, Campinas, 1991. Resumos. Campinas: ITAL, CTC, 1992. p.52-59.

SIMONSEN, B. Microbiological criteria for poultry products. In: MEAD, G.C. (Ed.). Processing of poultry. London: Chapman \& Hall, 1995. cap.7, p.221-250.

SLOAN, A.E. Bite-size goes big-time. Food Technology, v.53, n.7, p.30, 1999. 
SMITH, D.M. Functional properties of muscle proteins in processed poultry products. In: SAMS, A.R. Poultry meat processing. Boca Raton: Lewis Publishers, 2001. cap.11,p.181-194.

SOFOS, J.N.; BUSTA, F.F.; ALLEN, C.E. Influence of $\mathrm{pH}$ on Clostridium botulinum control by sodium nitrite and sorbic acid in chicken emulsions. Journal of Food Science, v.45, n.1, p.7-12, 1980.

SPECK, M.L.; RAY, B. Effects of freezing and storage on microorganisms in frozen foods: a review. Journal of Food Protection, v.40, n.5, p.333-337, 1977.

SPENCER, J.V.; SAUTER, E.A.; STADELMAN, W.J. Effects of freezing, thawing and storing broiler on spoilage, flavor and bone darkening. Poultry Science, v.40, p.918920, 1961.

SULZBACHER, W.L. Survival of microorganisms in frozen meat. Food Technology, v.4, n.8, p.386-390, 1950.

SULZBACHER, W.L. Effect of freezing and thawing on the growth rate of bacteria in ground meat. Food Technology, v.6, n.9, p.341-343, 1952.

SWIFT, C.E.; LOCKETT, C.; FRYAR, A.J. Comminuted meat emulsions: the capacity of meat for emulsifying fat. Food Technology, v.15, n.11, p.468-473, 1961.

TAKANO, M.; SIMBOL, A.B.; YASIN, M.; SHIBASAKI, I. Bactericidal effect of freezing with chemical agents. Journal of Food Science, v.44, n.1, p.112-115, 1979.

TOMPKIN, R.B.; CHRISTIANSEN, L.N.; SHAPARIS, A.B. Antibotulinal role of isoascorbate in cured meat. Journal of Food Science, v.43, n.5, p.1368-1370, 1978. 
TOMPKIN, R.B.; CHRISTIANSEN, L.N.; SHAPARIS, A.B. Iron and antibotulinum efficacy of nitrite. Applied Environmental Microbiology, v.37, n.2, p.351-353, 1979.

TRAKULCHANG, S.P.; KRAFT, A.A. Survival of Clostridium perfringens in refrigerated and frozen meat and poultry items. Journal of Food Science, v.42, n.2, p.518-521, 1977.

TROUT, G.R. Techniques for measuring water-binding capacity in muscle foods: a review of methodology. Meat Science, v.23, n.4, p.235-252, 1988.

VANDERZANT, C.; SPLITTSTOESSER, D.F. Compendium of methods for the microbiological examination of foods. 3.ed. Washington: American Public Health Association-APHA, 1992. 1919p.

VARELTZIZ, K.; BUCK, E.M.; LABBE, R.G. Effectiveness of betalains/potassium sorbate system versus sodium nitrite for color development and control of total aerobes, Clostridium perfringens and Clostridium sporogenes in chicken frankfurters. Journal of Food Protection, v.47, n.7, p.532-536, 1984.

VOLLER-REASONOVER, L.; HAN, I.Y.; ACTON, J.C., TITUS, T.C.; BRIDGES, W.C.; DAWSON, P.L. High temperature processing effects on the properties of fowl meat gels. Poultry Science, v.76, n.6, p.774-779, 1997.

WALTERS, C.L. Nitrate and nitrite in foods. In: HILL, M.J. (Ed.). Nitrate and nitrite in foods and water. New York: Ellis Horwood, 1991. cap.5, p.93-112.

WATSON, D.H. Nitrate, nitrite and $N$-nitrosamines. In: WATSON, D.H. Safety of chemicals in food: chemical contaminants. New York: Ellis Harwood, 1993. cap.4, p.63-75. 
WHITE, C.A.; HALL, L.P. The effect of temperature abuse on Clostridium perfringens and Bacillus cereus in raw beef and chicken substrates during frozen storage. Food Microbiology, v.1, n.2, p.97-104, 1984a.

WHITE, C.A.; HALL, L.P. The effect of temperature abuse on Staphylococcus aureus and Salmonellae in raw beef and chicken substrates during frozen storage. Food Microbiology, v.1, n.1, p.29-38, 1984 b.

WIERBICKI, E.; DEATHERAGE, F.E. Determination of water-holding capacity of fresh meats. Agricultural and Food Chemistry, v.6, n.5, p.387-392, 1958.

WOODS, L.F.J.; WOOD, J.M. A note on the effect of nitrite inhibition on the metabolism of Clostridium botulinum. Journal of Applied Bacteriology, v.52, n.1, p.109-110, 1982.

XAVIER, C.V.A.; BERAQUET, N.J. Vida-de-prateleira de carne mecanicamente separada de frango estocada sob refrigeração. Coletânea do Instituto de Tecnologia de Alimentos, v.1, n.24, p.91-104, 1994.

YARBROUGH, J.M.; RAKE, J.B.; EAGON, R.G. Bacterial inhibitory effects of nitrite: inhibition of active transport, but not of group translocation, and of intracellular enzymes. Applied and Environmental Microbiology, v.39, n.4, p.831-834, 1980. 